DOE/EIA- -0536

DE91 001726

\title{
The U.S. Petroleum Refining Industry in the 1980's
}

\author{
Energy Information Administration \\ Office of Oil and Gas \\ U.S. Department of Energy \\ Washington, DC 20585
}

\section{MASTER}

This report was prepared by the Energy Information Administration, the independent statistical and
analytical agency within the Department of Energy. The information contained herein should not be construed as advocating or reflecting any policy position of the Department of Energy or any other organization. 


\section{Contacts}

The U.S. Petroleum Refining Industry in the 1980's was prepared under the direction of Stephen K. Patterson by the staff of the Industry Analysis Branch, Petroleum Supply Division, Office of Oil and Gas of the Energy Information Administration (EIA). General information regarding this report can be obtained from Charles C. Heath, Director of the Petroleum Supply Division or Ronald W. O'Neill, Chief of the Industry Analysis Branch. Specific information regarding the preparation or content of this report may be obtained from Stephen K. Patterson (202) 586-5994. Questions on Chapter 2 concerning refinery configurations should be directed to Nancy Masterson (202, 586-8393; questions on Chapter 5 concernitg refinery ownership to David Hinton (202) 586-2990; and questions on refintry yields to Mary Zitomer (202) 586-8380. 


\section{Preface}

Section 205(a)(2) of the Department of Energy Organization Act of 1977 (Public Law 95-91) requires the Administrator of the Energy Information Administration (EIA) to carry out a central, comprehensive, and unified energy data information program that will collect, evaluate, assemble, analyze, and disseminate data and information. relevant to energy resources, reserves, production, demand, technology, and related economic and statistical information.

As part of the EIA program on petroleum, The U.S. Petroleum Refining Industry in the 1980's presents a historical analysis of the changes that took place in the U.S. petroleum refining industry during ine 1980's. It is intended to be of interest to analysts in the petroleum industry, State and Federal government officials, Congress, and the general public. The report consists of six chapters and four appendices. Included is a detailed description of the major events and factors that affected the domestic refining industry during this period. Some of the changes that took place in the 1980's are the result of events that started in the 1970's. The impact of these events on U.S. refinery configuration, operations, economics, and company ownership are examined.
The product demand forecasts used in this report were taken from the EIA's Annual Energy Outlook 1990 and Annual Outlook for Oil and Gas 1990. These forecasts were made prior to the Iraqi invasion into Kuwait on August 2, 1990. These forecasts represented expectations of what would occur under a given set of assumptions and did not provide unqualified predictions of the future. Worldwide events since the invasion that will affect future petroleum supply and demand relationships are still unfolding as this report is being prepared for publication. The long-term impact of the invasion and the general uncertainty inherent in forecasts contained in this report should be recognized, so that they can be used in the proper context.

The legislation that created EIA vested the organization with an element of statutory independence. Accordingly, this report offers an objective, independent analysis and does not purport to represent the policy position of the U.S. Department of Energy or the Administration. The responsibility of EIA is to provide timely, accurate information and to perform objective, credible analysis in support of deliberations by both public and private decisionmakers. 


\section{Contents}

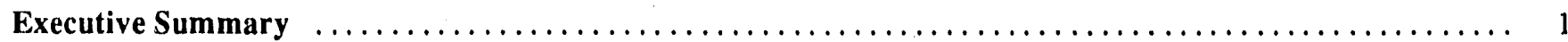

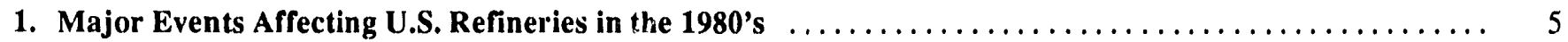

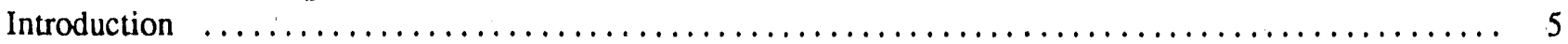

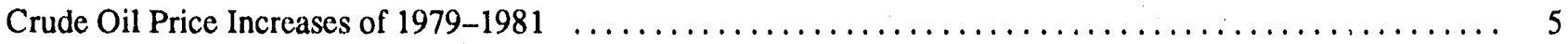

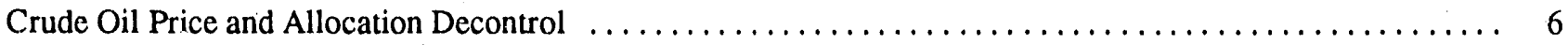

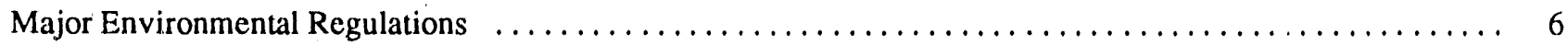

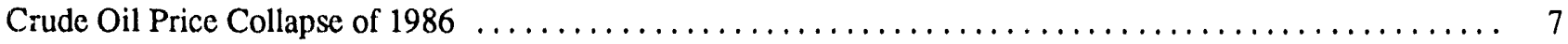

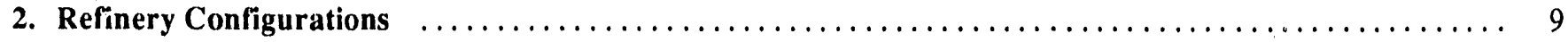

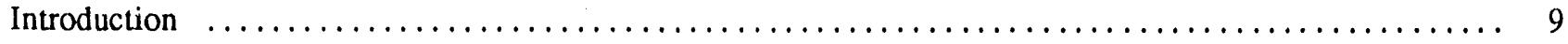

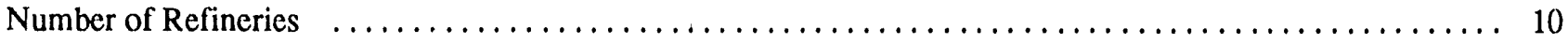

Operable Crude Oil Distillation and Downstream Processing Capacities $\ldots \ldots \ldots \ldots \ldots \ldots \ldots \ldots \ldots \ldots .11$

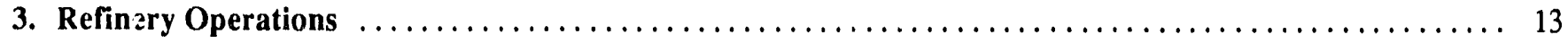

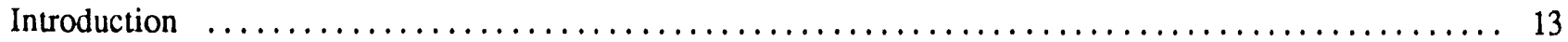

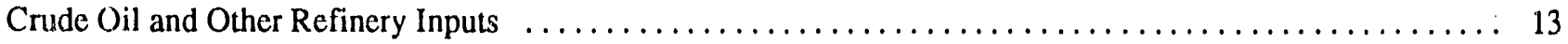

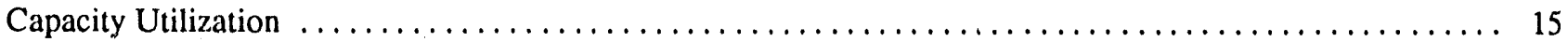

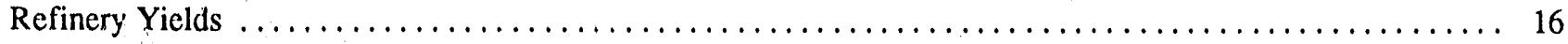

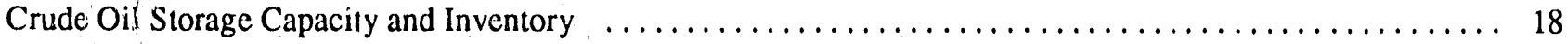

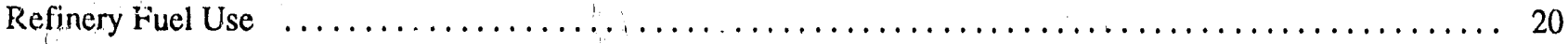

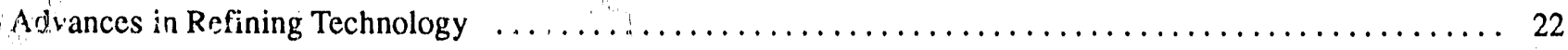

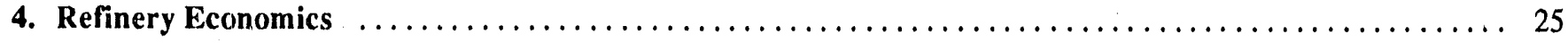

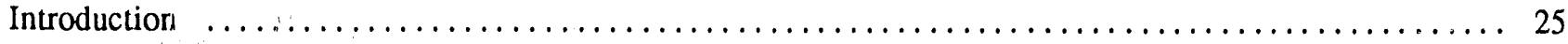

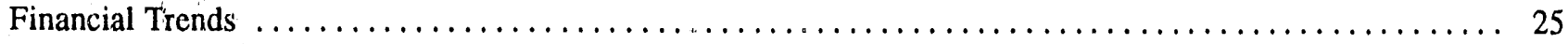

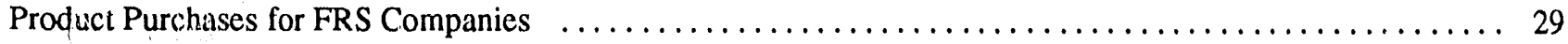

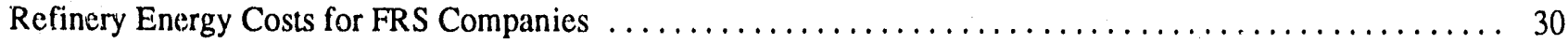

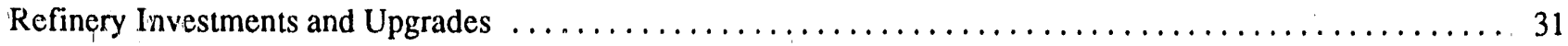

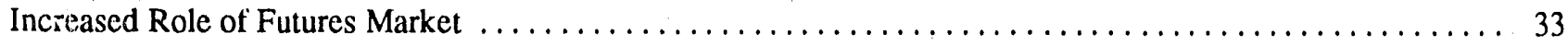

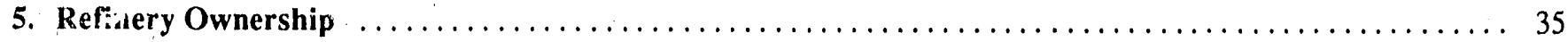

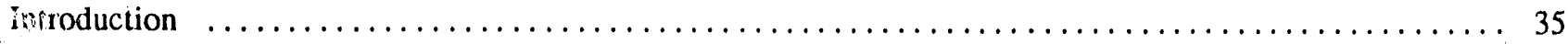

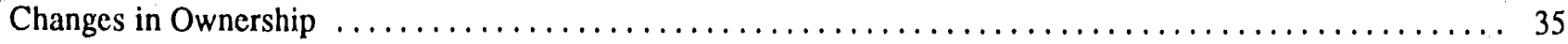

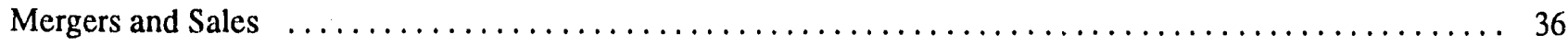

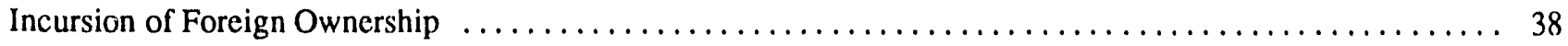




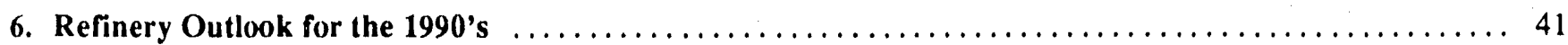

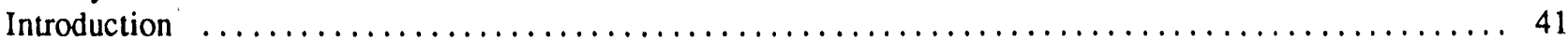

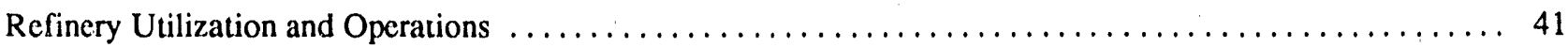

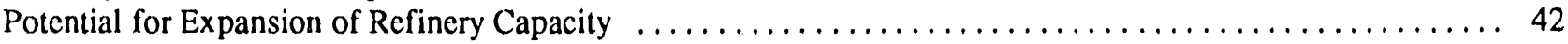

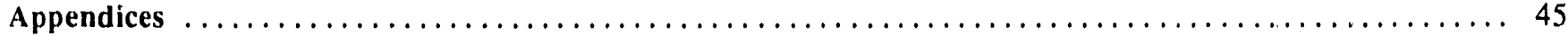

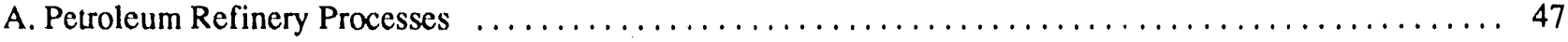

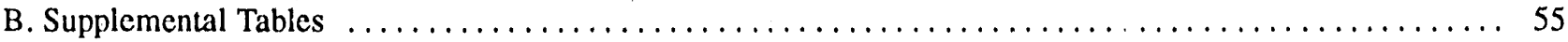

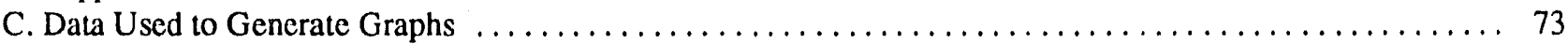

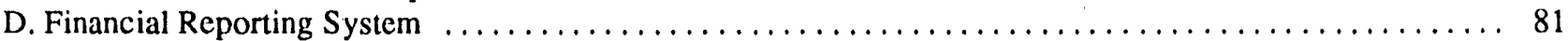

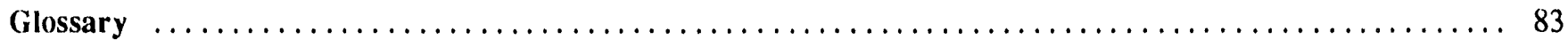

\section{Photo Credits}

Champlin Petroleum Co., page 3 (courtesy of the Ame ican Petroleum Institute).

Cities Service Co., page 11 (courtesy of the American Petroleum Institute).

Page 18 (courtesy of the American Petroleum Institute). 


\section{Tables}

1. Number and Operable Capacity of Petroleum Refinerics, $1980-1990 \ldots \ldots \ldots \ldots \ldots \ldots \ldots \ldots \ldots$

2. Number of Refineries by PAD District on January 1, 1980, 1985, and $1990 \ldots \ldots \ldots \ldots \ldots \ldots \ldots \ldots$

3. Average Refinery Inputs of Natural Gas Liquids and Other Liquids, $1980-1989 \ldots \ldots \ldots \ldots \ldots \ldots \ldots 14$

4. Refinery Yields by Refinery Type and Product Type, 1981, 1985, and $1989 \ldots \ldots \ldots \ldots \ldots \ldots \ldots \ldots$

5. Refinery Storage Capacity, Crude Oil and Refined Petroleum Products, $1980-1990 \ldots \ldots \ldots \ldots \ldots \ldots .19$

6. Domestic Raw Material Costs and Average Sale Price of Refined Products for FRS Companies, $1977-1988$............................................ 26

7. Refined Product Costs and Margin as a Percentage of Product Revenues for FRS Companies, 1977-1988 _. 27

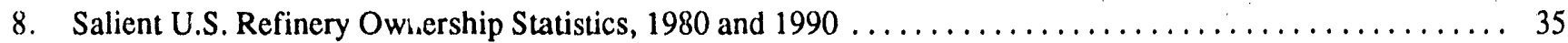

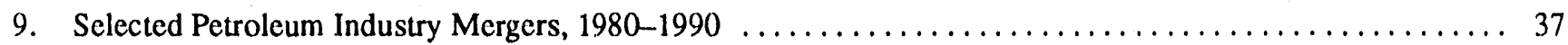

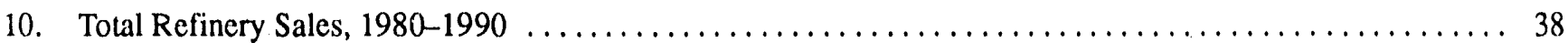

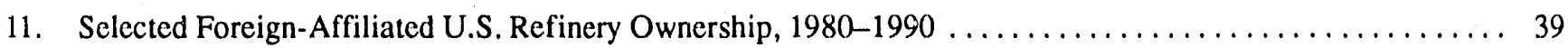

B1. Refineries Shutdown Between 1980 and 1990, by Year and Complexity $\ldots \ldots \ldots \ldots \ldots \ldots \ldots \ldots \ldots$

B2. Refineries Permanently Shutdown Between January 1, 1980 and January 1, 1990, by PAD District ....... 61

B3. Refineries Reactivated Between January 1, 1980 and January $1,1990 \ldots \ldots \ldots \ldots \ldots \ldots \ldots \ldots \ldots \ldots . \ldots 6$

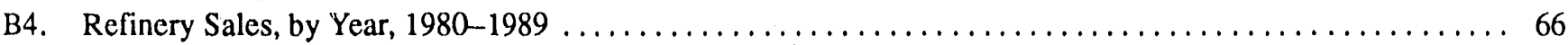

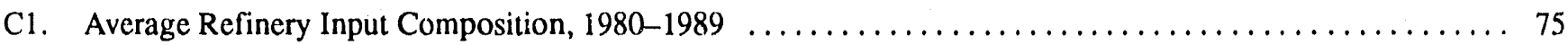

C2. Average Sulfur Content of Crude Oil Inputs to Refineries, $1981-1989 \ldots \ldots \ldots \ldots \ldots \ldots \ldots \ldots \ldots \ldots \ldots$

C3. Average API Gravity of Crude Oil Inputs to Refineries, $1981-1989 \ldots \ldots \ldots \ldots \ldots \ldots \ldots \ldots \ldots \ldots \ldots$

C4. Average Operable Refinery Utilization Rate, $1980-1989 \ldots \ldots \ldots \ldots \ldots \ldots \ldots \ldots \ldots \ldots \ldots \ldots \ldots . \ldots \ldots$

C5. Refinery Yields of Major Petroleum Products, $1980-1989 \ldots \ldots \ldots \ldots \ldots \ldots \ldots \ldots \ldots \ldots \ldots \ldots \ldots$

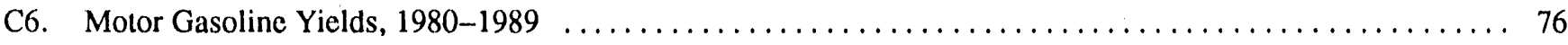

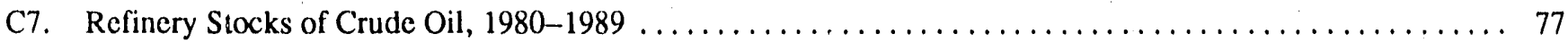

C8. Refinery Stocks of Petroleum Products, $1980-1989 \ldots \ldots \ldots \ldots \ldots \ldots \ldots \ldots \ldots \ldots \ldots \ldots \ldots \ldots \ldots$

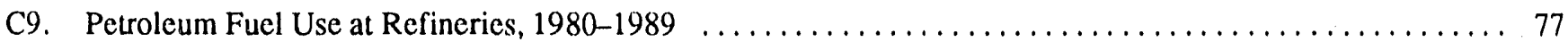

C10. Natural Gas Use at Refineries, $1980-1989 \ldots \ldots \ldots \ldots \ldots \ldots \ldots \ldots \ldots \ldots \ldots \ldots \ldots \ldots \ldots \ldots \ldots$

C11. Purchased Electricity Use at Refineries, $1980-1989 \ldots \ldots \ldots \ldots \ldots \ldots \ldots \ldots \ldots \ldots \ldots \ldots \ldots \ldots$

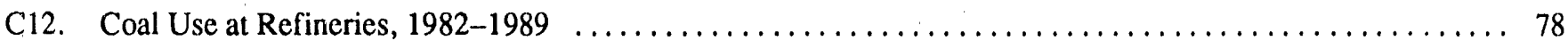

C13. Domestic Refined Product Margins for FRS Companies, 1977-1988 . . . . . . . . . . . . . . . . . . . 78

C14. Relativc Contributions of Domestic Production, Refining/Marketing, and Pipelines to Total

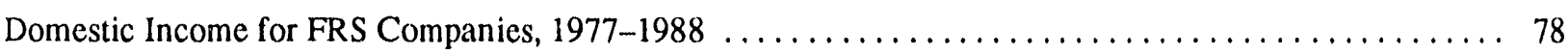

C15. Domestic Refinery Energy Expense for FRS Companies, $1977-1988 \ldots \ldots \ldots \ldots \ldots \ldots \ldots \ldots \ldots \ldots . \ldots$

C16. Additions to Investment for Domestic Petroleum Refining for FRS Companies, 1977-1988 . . ........ 79

C17. Number of U.S. Refining Companies by Major and Non-Major Company Ownership, 1980-1990 _ . . . . . . 79

C18. Crude Oil Distillation Capacity by Major and Non-Major Company Ownership, 1980-1990 . ........ 79

C19. Number of U.S. Refineries by Major and Non-Major Company Ownership, 1980-1990 _.......... 80

C20. U.S. Crude Oil Distillation Capacity by Foreign-Affiliated and U.S.

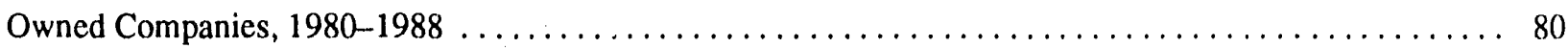

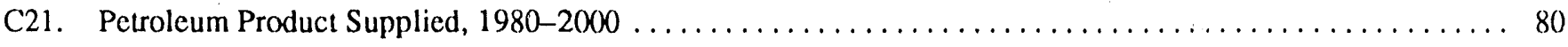




\section{Figures}

1. Major Events Affecting U.S. Petroleum Refineries $1970-1989 \ldots \ldots \ldots \ldots \ldots \ldots \ldots$

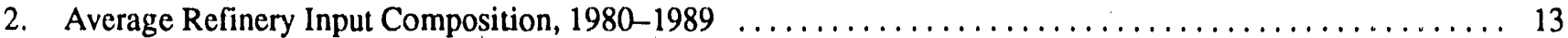

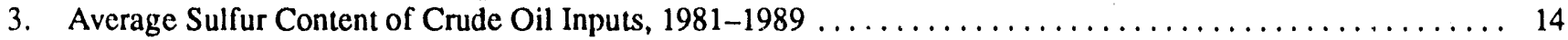

4. Average API Gravity of Crude Oil Inputs, $1981-1989 \ldots \ldots \ldots \ldots \ldots \ldots \ldots \ldots \ldots \ldots$

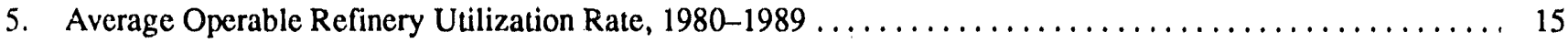

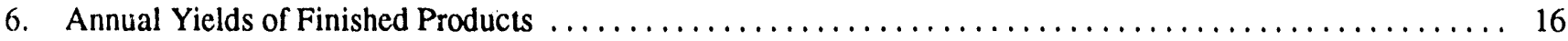

7. Refinery Yields of Major Petroleum Products, $1980-1989 \ldots \ldots \ldots \ldots \ldots \ldots \ldots \ldots$

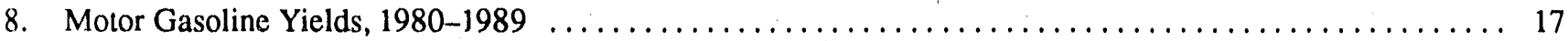

9. Year-End Refinery Stocks of Crude Oil $1980-1989 \ldots \ldots \ldots \ldots \ldots \ldots \ldots \ldots \ldots \ldots$

10. Refinery Stocks of Petroleum Products, $1980-1989 \ldots \ldots \ldots \ldots \ldots \ldots \ldots$

11. Petroleum Fuel Use at Refineries, $1980-1989 \ldots \ldots \ldots \ldots \ldots \ldots \ldots \ldots$

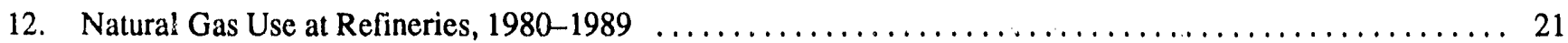

13. Purchased Electricity Use at Refineries, $1980-1989 \ldots \ldots \ldots \ldots \ldots \ldots \ldots \ldots$

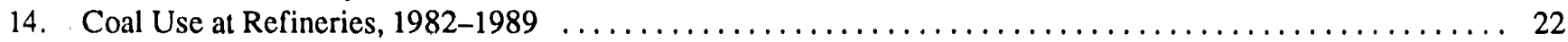

15. Domestic Refined Product Margins for FRS Companies, 1977-1988 . . . . . . . . . . . . . . . . 25

16. Relative Contributions of Domestic Production, Refining/Marketing, and Pipelines to Total

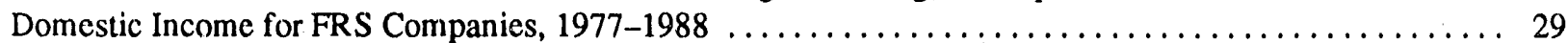

17. Domestic Refinery Energy Expense for FRS Companies, $1977-1988 \ldots \ldots \ldots \ldots \ldots$

18. Additions to Investment for Domestic Petroleum Refining for FRS Companies, 1977-1988 . . . . . . . . . 31

19. Number of U.S. Refining Companies, by Major and Non-Major Company Ownership, 1980-1990 . . . . . . 36

20. Crude Oil Distillation Capacity, by Major and Non-Major Company Ownership, 1980-1990 . . . . . . . . . 36

21. Number of U.S. Refineries, by Major and Non-Major Company Ownership, 1980-1990 . . . . . . . . . . . 36

22. Percent of U.S. Crude Oil Distillation Capacity by Foreign-Affiliated and U.S.

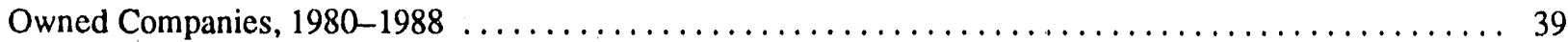

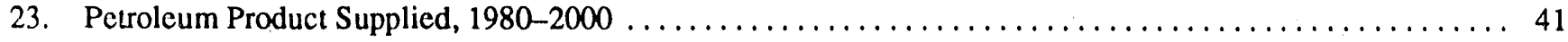

A1. 1989 Refinery Yields (Percent) and Petroleum Product Uses $\ldots \ldots \ldots \ldots \ldots \ldots \ldots$

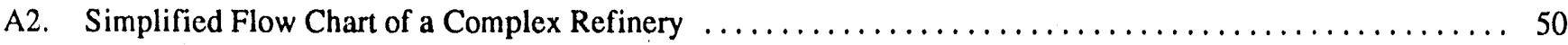

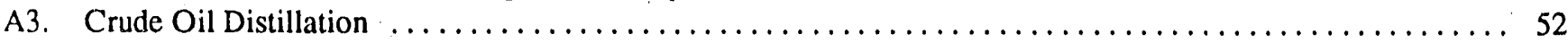




\section{Executive Summary}

\section{Introduction}

The U.S. petroleum refining industry was faced with many diverse challenges during the 1980's. In many respects, the refining industry that entered the decade was quite different from that which emerged. Prior to the 1980's, most changes at refineries were the result of long-term strategic planning that took into account factors such as the multi-year implementation of long standing legislation (Clean Air Act of 1970) and gradual changes in consumer preferences. During the 1980's, the U.S. refining industry continued to be influenced by these types of events. However, unique events that occurred during and just prior to the 1980's influenced the U.S. refining industry to change more rapidly than during any other 10-year period since World War II (Figure 1).

The four most significant events that affected the U.S. petroleum refining industry during the 1980's were:

- The crude oil price increases between 1979 and 1981. This price spiral was sparked by the Iranian Revolution, and is reflected in the rise in the annual U.S. composite refiner acquisition cost of crude oil from $\$ 12.46 \mathrm{per}$ barrel in 1978 to $\$ 35.24$ per barrel in 1981 .

- The complete removal of crude oil price and allocation controls in 1981. In early 1981, President Reagan's administration removed all remaining price and allocation controls on crude oil and petroleum products. Market forces replaced regulatory programs in determining crude oil production and price levels, and allocation of crude oil supplies.

- The implementation of major environmental regulations. Regulations issued by the Environmental Protection Agency (EPA) to reduce permissible levels of lead in motor gasoline and restrict summertime motor gasoline volatility increased the pressure on downstream capacity and tested refinery flexibility.

- The crude oil price collapse of 1986. In early 1986, world oil markets experienced the third major price shock in 15 years, as crude oil prices plummeted. The crisis arose in September 1985 when Saudi Arabia, in

Figure 1. Major Events Affecting U.S. Petroleum Refineries, 1970-1989

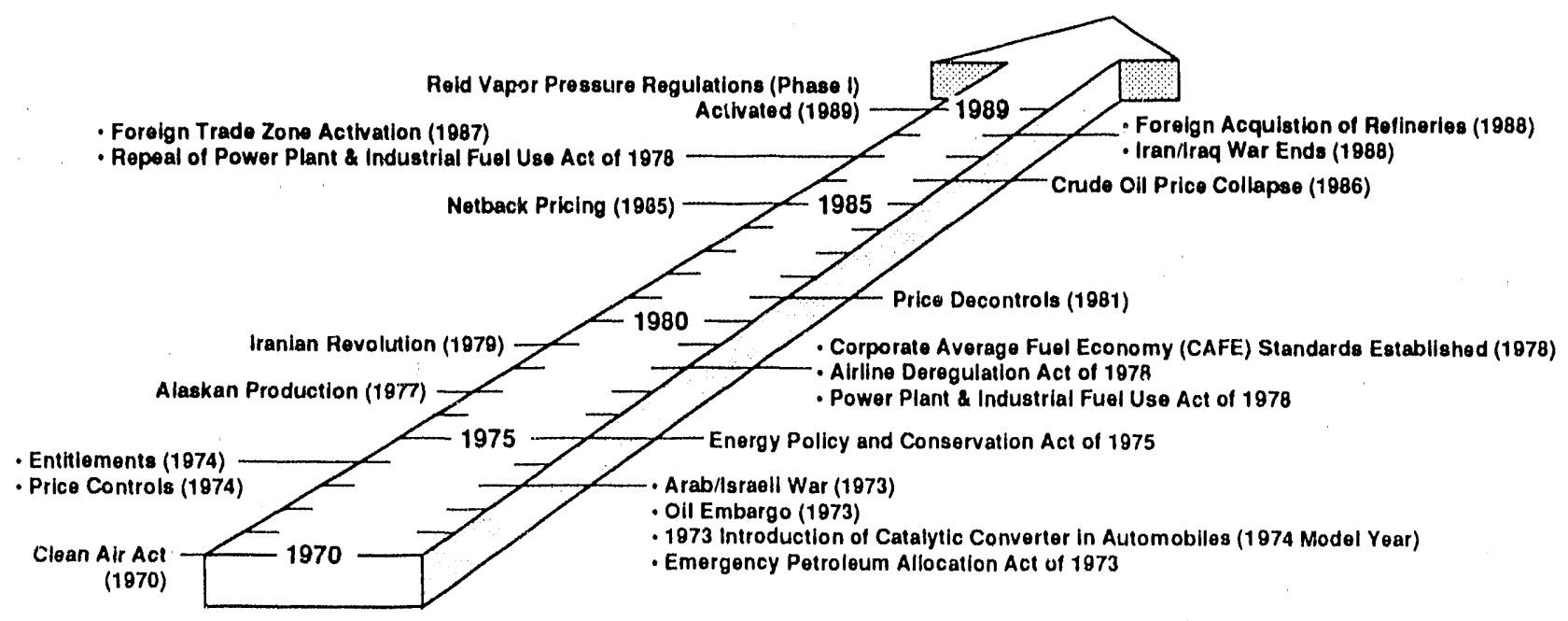


response to severe quota-cheating by its OPEC partners, abandoned its role as swing producer and introduced netback pricing ${ }^{1}$ of crude oil, as it embarked on a program to increase production to raise its market share. Increased crude oil production, widespread market-related pricing, and slack demand caused average crude oil acquisition costs in the United States to fall from $\$ 26.75$ per barrel in 1985 to $\$ 14.55$ per barrel in 1986.

\section{Changes and Trends in U.S. Refining in the 1980's}

The refit ing industry responded to these four major events by becoming leaner and more flexible. These events plus lesser events, such as the Airline Deregulation Act of 1978 and the Power Plant and Industrial Fuel Use Act of 1978 were the driving forces behind the changes in refinery trends in the 1980's.

The first half of the decade can be characterized as a period of transition and consolidation. During this period, refiners had to adjust rapidly to high-priced crude oil, declining demand and price and allocation decontrol. At the same time, shifting product mixes and environmental regulations affecting gasoline production placed greater emphasis on downstrcam processing capacity (capacity of units that process intermediate product called unfinished oils 'downstream' or after crude oil is initially processed in crude oil distillation units) and prompted investments in this area.

\section{Refinery Configurations}

Refinery configuration is a term that refers to the various types of processing units located at a refinery. Refineries are configured based on the desired product to be produced and the quality of the raw materials being processed. Complexity of a refinery is related to the types of processing units a refinery has to convert crude oil and other raw materials into finished petroleum products. Some of the significant changes to refinery configurations during the 1980's were:

- Refinery crude oil distillation capacity (capacity rate at which crude oil can be processed in a crude oil distillation unit) decreased dramatically between January 1 ,
1980, and January 1, 1990, as the number of operable refineries in the United States decreased from 319 on January 1, 1980, to 205 on January 1, 1990. Most of these closings occurred in the 2 years immediately following decontrol of crude oil price and allocation in carly 1981.

- Refineries that shut down during the 1980's were typically small, independent facilities with less than 30,000 barrels per day of crude oil distillation capacity and no downstream capacity. The relative lack of processing flexibility at small refineries placed them at a competitive disadvantage after the elimination of crude oil price and allocation controls.

- Although the number of operable refineries decreased during the 10-year period, downstream processing capabilities grew as complex refineries became more sophisticated. Expansions and upgrades in motor gasoline production capacity were made in order to meet EPA restrictions on lead content and volatility, as well as to satisfy the growing demand for higher octane gasoline.

\section{Refinery Operations}

Refinery operations include the types, quality, and quantity of raw materials processed (input) at refineries; the efficiency or utilization rates of processing units; the production yields of products; storage capacity and inventory, fucls consumed at refineries, refinery technology, and application of computer technology to refining. Some of the significant changes in refinery operations during the 1980's were:

- Total raw material input to refincries decreased during the early 1980's due to falling demand for petroleum products. Inputs began to rise in 1984 as demand for petroleum products increased. Changes in demand were related to large product price swings.

- The quality of crude oil inputs declined during the 1980's. Lighter, lower sulfur crude oils were replaced with heavier, higher sulfur blends that rey. id more refinery processing to meet consumer needs. By running poorer grade crude oils, sophisticated refineries could reduce raw material cost.

- The most significant change in refinery yields during the 1980's occurred in the production share of leaded

1 Netback pricing was an arrangement which protected the refiners (buyers) from subsequent product price cuts by tying the price of crude oil to the sales price of refined products less refining and transportation costs. 


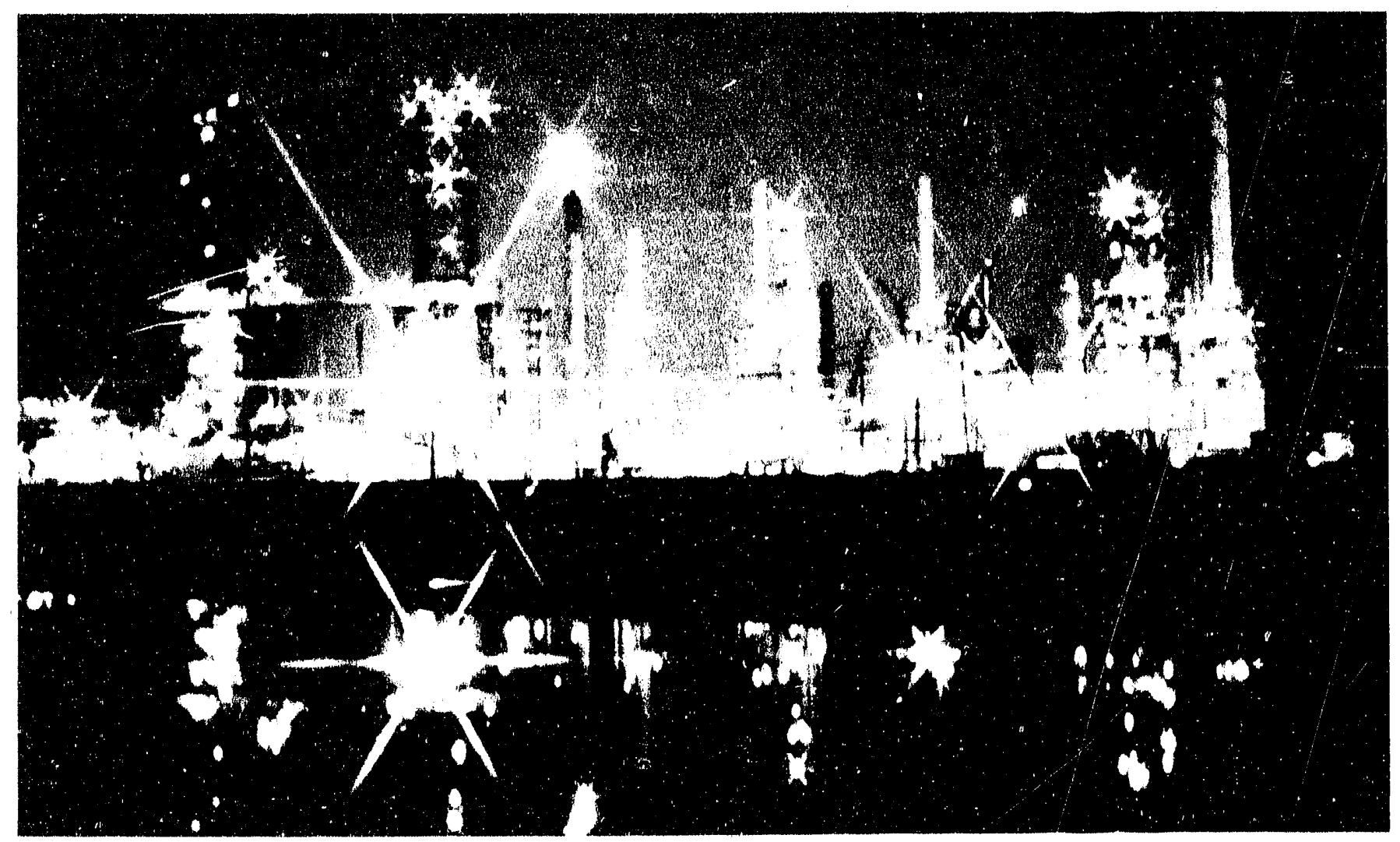

Except during periods of maintenance, refineries are normally operated around the clock every day to process crude oil.

and unleaded gasoline. The production share for unleaded gasoline moved from less than 50 percent in 1980 to almost 90 pereent in 1989. Lead phase down requirements led U.S. refiners to increase the use of downstream processing and introduce additives such as mothyl tertiary butyl ether to increase the octane level of motor gasoline and maintain yiclds.

- Stocks of crude oil and petroleum products held at refineries were reduced through measures such as improved inventory management. This reduced financial risks associated with inventories and helped to reduce opcrating costs.

- Refinery use of petrolcum fucls increased during the 1980's as energy-intensive downstream units became more widely used.

- Advances in refining technology during the 1980's included the introduction of octane-enhancing catalysts and increased use of sophisticated computer applications. These developments have increased efficiency and cut operating costs.

\section{Refinery Economics}

The topics examined concerning refinery economics are trends in refined product margins, financial contributions of different operational sectors (i.e., refining/marketing, production, and pipelines), product purchases, energy expenses, investments in upgrades, and the increased role of the futures market in reducing financial risk. Significant changes involving refinery economics during the 1980's were:

- After the decontrol of crude oil prices in carly 1981, the financial performance of the refining/marketing sector was characterized by retrenchment and consolidation, and generally lower financial performance.

- Vertical integration of oil companies (oil companies whose operations include crude oil production, refining, and marketing) contributed to the financial stability of domestic petroleum operations during periods of crude oil price instability.

- Throughout the decade, but particularly after 1985 , product purchases (where refiners buy finished petroleum products as opposed to refining the product 
themselves) became increasingly important to inventory management and accounted for a larger portion of refining/marketing costs.

- Energy expenses at refineries peaked in 1981 and declined steadily for the remainder of the decade. This occurred despite the fact that more energy was consumed at refincries. However, energy expenses as a percentage of refined product revenues remained fairly consistent throughout the decade, indicating that changes in energy costs are reflected in product prices.

- Investments in domestic refining in the 1980's went primarily into upgrading and expanding downstream capacity. After peaking in 1982, refinery investment declined steadily throughout most of the decade. Investments rebounded sharply in 1988 in anticipation of environmental regulations restricting gasoline volatility and sulfur content in diesel fuel. Investments in downstream capacity increased the flexibility of U.S. refincries.

- Since 1985 , refiners have become increasingly more active players in oil futures markets. Refiners typically employed a hedging strategy to protect against rapid and large swings in crude oil and product prices.

\section{Refinery Ownership}

Ownership of U.S. refineries changed appreciably in the 1980's, as mergers, takeovers, and foreign investments altered the structure of the refining industry. Significant changes involving refinery ownership during the 1980's were:

- Refinery shutdowns and company mergers within the petroleum industry reduced the number of refining companies by nearly 43 percent between 1980 and 1990. An important factor driving the large-scale mergers was the make or" buy decision regarding crude oil reserve additions.

- Foreign investor interest in the U.S. refining industry more than doubled in the 1980's, as foreign-affiliates' share of total crude oil distillation capacity reached 27.1 percent in 1988 compared with 11.1 percent in 1980. Statc-run oil companies of some large crude oil producing countries found U.S. refineries a stable outIet for their crude oil which also provided access to product markets.

\section{Outlook for the 1990's}

The U.S. refining industry has faced a number of technical and economic challenges during the 1980's brought about by changes in petroleum product demand, government regulations, including the end of crude oil price and allocation controls, and environmental initiatives such as the lead phasedown. In the 1990's, the refining industry will continue to face similar types of challenges.

Although the cconomic factors affecting refinery expansion decisions improved during the late 1980 's, more restrictive environmental regulations will make it more difficult, if not economically prohibitive, to increase capacity through new refincry construction. Considering the forecast of increasing petroleum product demand through the year 2000, without new refinery construction the U.S. refining industry will be pressed to operate at high utilization rates to meet growing petroleum product demand. In addition, demand for light products such as motor gasoline are projected to continue to dominate petroleum demand through the 1990's, leading to the requirement for greater utilization of downstream processing units.

Even though U.S. refinery capacity is not expected to grow significantly in the United States over the next few years, it is expected that refinery capacity will increase overseas. For example, in the Caribbean region, there are plans for over 500,000 barrels per day of new crude oil distillation capacity and at least 125,000 barrels per day of catalytic cracking capacity by the mid-1990's. ${ }^{2}$ The Caribbean refinerics can be expected to provide a growing share of petroleum products to the U.S. East Coast in the future.

Crude oil costs to refincis are expected to increase during the 1990's. This will place pressure on refiners to cut costs in other areas in order to maintain profits.

New environmental regulations will have a significant impact on refinery operations. According to industry sources, refinery operating costs will substantially increase during the 1990's. New clean air legislation will make it necessary for refiners to invest heavily in pollution control equipment, downstream processing units, and additional units to produce motor gasoline additives such as methyl tertiary butyl ether (MTBE).

2 "Caribbean Refining Gears Up for a Rebound," Petroleum Intelligence Weekly (June 18, 1990), p. 5. 


\section{Major Events Affecting U.S. Refineries in the 1980's}

\section{Introduction}

The U.S. petroleum refining industry went through many important changes during the 1980's. Starting in the 1970's and continuing into the 1980's, many significant events occurred that reshaped the U.S. refining industry.

Most petroleum refineries are complex industrial facilities with large capital investments in equipment, operations, and raw materials. Prior to the 1980 's, most changes at refineries were based on long-term strategic planning that took into account factors such as gradual changes in consumer preferences and the multi-year implementation of long standing legislation (Clean Air Act of 1970). During the 1980 's, the U.S. refining industry continued to be influenced by these factors, however, unique events that $\mathrm{oc}$ curred during the 1980's had a significant impact on the structure and operations of the industry.

The four most significant events that affected the U.S. petroleum refining industry during the 1980's were:

- The crude oil price increases from 1979 to 1981.

- The complete removal of crude oil price and allocation controls in 1981.

- The implementation of major environmental regulations beginning in 1970.

- The crude oil price collapse of 1986.

\section{Crude Oil Price Increases, 1979-1981}

Ushering in the decade was the second major oil shock of the 1970's, an event that set the stage for much that was to follow in the 1980's. The 1979 to 1981 crude oil price spiral was sparked by the Iranian Revolution. The political unrest that began in the cities of Iran in the summer of 1978 soon spread to the oil fields. Crude oil production in Iran fell dramatically.

The political upheaval in Iran and cuts in total OPEC production led to increased stock buildup activity as companies and governments sought to build re:serve supplies. Decreasing crude oil supplies and the building of stocks exerted tremendous upward pressure on the world price of crude oil. In September 1980, soon after the outbreak of the Iran-Iraq war, crude oil spot prices soared to a peak of nearly $\$ 40.00$ per barrel. In the United States, refiner acquisition costs of crude oil mirrored these increases, rising from a composite average ${ }^{3}$ of $\$ 12.46$ per barrel in 1978 to an average of $\$ 35.24$ per barrel in 1981 .

In the United States, higher crude oil prices depressed consumption and encouraged energy conservation and fuel switching away from petroleum, reducing U.S. petroleum product demand from 18.9 million barrels per day in 1978 to 16.1 million barrels per day in 1981. By 1983, U.S. demand averaged 15.2 million barrels per day, its lowest level since 1971. These events, in turn, were the driving forces behind the decline of crude oil input at refineries from 14.7 million barrels per day in 1978 to 11.7 million barrels per day in 1983 .

3 Weighted average of refiner acquisition costs for domestic and foreign crude oils. 


\section{Crude Oil Price and Allocation Decontrol}

In early 1981, President Reagan's administration removed all remaining price and allocation controls on crude oil and petroleum products. While some aspects of the domestic refining industry were regulated by the Federal Government beginning in 1959, in 1973 the Federal Government assumed a significant amount of regulatory authority over the oil industry. The expanded scope of regulatory control of the vil industry between 1973 and 1980 was a response to the 1973 Arab oil embargo and grew out of the price controls placed into effect under the Economic Stabilization Program begun in 1971 .

The majority of the regulations during this period were established by the Emergency Petroleum Allocation Act of 1973 and were augmented by the Energy Policy and Conservation Act of 1975, and the Energy Conservation and Production Act of 1976.

The three major regulatory prograrns that affected U.S. refiners the most in the 1970's and into the 1980's were the Suppliers-Purchasers Rule, the Buy-Sell Program, and the Crude Oil Entitlements Program. These programs assured supply and subsidized prices for smaller refineries. Under the Suppliers-Purchasers Rule, existing transaction relationships among crude oil producers, refiners, resellers, and retailers were essentially frozen. With the allocation of crude oil no longer subject, to the workings of the free market, the Buy-Sell Proglam was created to correct imbalances in crude oil supply among refineries. The program established a proportional allocation plan based on refinery capacity. Refiners receiving more than their regulated allowance of crude oil were required to resell at controlled prices some of their excess supply to refiners with less access to a stable source of supply. ${ }^{4}$ The large differences in domestic and world crude oil prices engendered by price controls led to the development of the Crude Oil Entitlements Program. This program was a complex system designed to eliminate price variations between foreign and domestic sources of crude oil.
By the end of the 1970's, an intricate system of regulatory programs had evolved covering nearly all aspects of the petroleum industry. Becausiz of the favorable treatment small refiners received under these programs, construction and reactivation of small refineries were stimulated. From the beginning of 1973 to the beginning of 1981, the number of refineries in the United States swelled from 268 to 324 , anc' crude oil distillation capacity increased by almost 5.0 million barrels per day. The bulk of these new refineries were small, with crude oil distillation capacity of less than 30,000 barrels per day and little downstream processing.

Although the price and allocation controls placed on the domestic oil indusiry stimulated the construction of small refineries, these controls also reduced incentives for domestic exploration and production, diminished the ability of the domestic industry to react to market signals, and created inefficiencies in refinery utilization. Between 1972 (the year before price controls were imposed) and 1979, crude oil production in the Lowcr 48 States dropped by 2.1 million barrels per day to 7.2 million barrels per day. ${ }^{5}$ Crude oil imports rose dramatically, from 2.2 million barrels per day in 1972 to nearly 6.5 million barrels per day in $1979 .^{6}$

To encourage domestic crude oil production, President Carter's administration introduced in 1979 a phased program of regulatory decontrol. ${ }^{7}$ Soon after his inauguration in 1981, President Reagan ordered the total decontrol of crude oil prices and the elimination of allocation programs. Market forces replaced regulatory programs in deternining crude oil production and price levels, and in allocating crude oil supplies.

\section{Major Environmental Regulations}

Federal environmental regulations governing the content and characteristics of petroleum products had a significant impact on refinery operations in the 1980's. Regulations issued by the Environmental Protection Agency (EPA) reducing permissible levels of lead in motor gasoline and, more recently, restricting summertime motor gasoline

\footnotetext{
4 Soon after the Buy-Sell Program was implemented, its requirements were adjusted so that the sell requirements were limited to the 15 largest integrated refiners and the buy requirements to small refiners.

5 Total domestic production over the same period, however, did not fall as much because of production from Alaska's Nerth Slope (ANS) in 1977. By 1979, ANS crude oil was contributing 1.4 million barrels per day to U.S. production.

6 Excludes imports for the Strategic Petroleum Reserve.

7 As part of the phased decontrol of crude oil prices in 1979. Congress enacted the Windfal' l'rofits Tax in 1980, an excise tax based on the selling price of crude oil. This tax stayed on the books until August 1988, when it was repealed.
} 
volatility, were two major initiatives that increased the pressure on downstream capacity and tested refinery flexibility.

\section{Lead Phase-Down}

Since the carly 1920's, lead-based compounds have been used in motor gasoline blending. In 1970, the Clean Air Act regulated the amount of lead additives in motor gasoline. The legislation established a schedule for reducing octaneenhancing additives using lead and required automobile manufacturers to build new cars and trucks that could use unleaded fuel. During the 1970's, the demand for unleaded gasoline expanded rapidly, accounting for nearly 40 percent of total motor gasoline demand in 1979. The demand for unleaded gasoline continued to rise in the 1980's and, by the end of the decade, unleaded gasoline accounted for nearly 90 percent of all motor gasoline sold.

\section{Motor Gascline Volatility Regulations}

In the spring of 1989, the EPA issued regulations on reducing summertime motor gasoline volatility. The new EPA $R$ 'id Vapor Pressure (RVP) standards sought to significantly reduce emissions of ozone-producing volatile organic compounds (VOCs) from evaporating motor gasoline.

The refining industry measures gasoline volatility in terms of RVP, or the measure of the surface pressure at which liquid gasoline turns to vapor. Vapor pressure, expressed in pounds per square inch (psi), is the measure of when a substance in a liquid state evaporates and becomes a gas. Motor gasoline with a high RVP vaporizes much quicker than gasoline with a lower RVP. Temperature and elevation also affect the evaporative levels of gasoline. Since atmospheric pressure decreases with altitude, so does the need for higher RVP gasoline. Moreover, the lower the temperature, the greater the need for higher RVP gasoline.

The regulations which are now in effect from May 1 to September 15 of each year will be implemented in two phases. Phase I of the plan, which went into effect in June 1989, mandated a reduction from the nationwide average RVP of 11.5 pounds per square inch ( $\mathrm{psi}$ ) to a range between $9.0 \mathrm{psi}$ and $10.5 \mathrm{psi}$ RVP, depending upon the area of the country. Phase II is set to begin in 1992 and will restrict the southern half of the Nation to burn $9.0 \mathrm{psi}$ fuel in May and then switch to $7.8 \mathrm{psi}$ fuel from June through September 15 . The 26 northem States will lirnit gasoline volatility to 9.0 psi from May 1 through September 15. EPA estimates that Phase II will cut overall emissions of VOCs by 7 percent nationally.
In issuing the RVP regulations, EPA noted that Phase I of the volatility reductions could be attained without installing new capital equipment at refineries. The 3-year transition period between the two regulatory phases was provided to give refiners sufficient lead time to make the necessary processing changes to meet the stricter 1992 RVP standards. Compliance with the Phase I standards was achieved by reducing the amount of normal butane blended into motor gasoline. To compensate for the reduction in butane, refiners intensified the use of catalytic cracking and alkylation units. (Sce Appendix A.) How wever, normal butane is a valuable motor gasoline component because it is relatively inexpensive (compared with other motor gasoline blend stocks), has a high octane rating, is readily available, and adds volume to the motor gasoline pool.

Production alternatives that simultancously allow refiners to achieve lower volatility and maintain octane requirements irclude increasing the volume of motor gasoline additives such as oxygenates, alcohol, and aromatics. Oxygenates, such as methyl tertiary butyl ether (MTBE) and ethyl tertiary buty! ether (ETBE) are relatively expensive and in short supply in many areas of the country, and alcohol additives are currently restricted to a percentage of the gasoline pool. Raising the level of aromatics such as benzene in motor gasoline is a short-term response since EPA is considering limiting the aromatic content of motor gasoline. New gasoline blends, or reformulated gasolines have been introduced in some U.S. markets. In the meantime, octane lost in the process of meeting the new volatility requirements is being replaced by increasing the utilization of existing downstream conversion units.

\section{Diesel Fuel Oil Regulations}

EPA recently issued regulations that reduces the allowable sulfur level in diesel fuel oil. The EPA rules lower the maximum allowable sulfur content of diesel fuel from 0.265 percent by weight to 0.05 percent. Reducing the sulfur content of diesel fuel places an additional burden on existing hydrotreating units and stimulates additional investment in hydrotreating capacity. (See Appendix A.)

\section{Crude Oil Price Collapse of 1986}

In early 1986, world oil markets experienced the third major crude oil price shock in 15 years, but this time crude oil prices plummeted. As a result of the increase in non-OPEC crude oil supplies between 1981 and 1985, OPEC market share was reduced. Some OPEC members attempted to 
offset their revenue losses and regain market share by offering attractive prices and by increasing their production above established quotas. In late 1985, Saudi Arabia, frustrated with rampant quota-cheating by its OPEC partners, abandoned its role as a swing producer. In September, Saudi Arabia introduced netback pricing ${ }^{8}$ of crude oil and embarked on a program to increase production to increase its market share. Other producing countries also began to increase production and lower prices to attract buyers, resulting in a surge of OPEC crude oil production.

In 1986, OPEC production was 2.1 million barrels per day higher than in 1985, with Saudi Arabia accounting for 70 percent of the increase. Increased crude oil output, widespread market-related pricing, and slack demand caused crude oil prices to plunge below $\$ 12.00$ per barrel during the year. This compares with the 1985 average U.S. refiner acquisition cost of $\$ 26.75$. Extensive trading in netback-priced crude oil was a boon to refiners because it guaranteed refining margins during a period of price instability. Crude oil acquisition costs in the United States fell from $\$ 26.75$ per barrel in 1985 to $\$ 14.55$ per barrel in 1986 , and averaged $\$ 16.84$ per barrel for the remainder of the decade.

The sharp drop in crude oil prices helped stimulate additional economic growth in the United States and contributed significantly to the steady increase in U.S. demand for petroleum products. From 15.7 million barrels per day in 1985, petroleum product demand climbed to 17.3 million barrels per day in 1989 , an increase of nearly 10 percent.

8 Netback pricing was an arrangement which protected the refiners (buyers) from subsequent product price cuts by tying the price of crude oil to the sales price of refined products less refining and transportation costs. 


\section{Refinery Configurations}

\section{Introduction}

Refinery configuration is a term that refers to the various types of processing units ${ }^{9}$ located at a refinery. Refineries are configured based upon the desired product to be produced and the quality of the raw materials being processed. Complexity of a refinery is related to the types of processing units at the facility to convert crude oil and other raw materials into finished petroleum products.

There were significant changes in the structure and configuration of U.S. petroleum refineries during the 1980's. The decade was characterized by a 36-percent decrease in the number of refineries operating, corresponding to the loss of 2.4 million barrels per day in crude oil processing capability (Table 1). In contrast, there were significant increases in downstream processing units, increasing overall refinery flexibility (complexity).

For purposes of comparison, refineries are grouped by category of complexity:

- Simple refineries are those that can only process crude oil to one level of distillation. That is, they do not have the capability (downstream processing units) to change the boiling range of the material they process. They typically have only a crude oil distillation unit and possibly a reformer unit.

- Complex refineries can convert material from one boiling range to another. They are capable of convert-

Fable 1. Number and Operable Capaclty of Petroleum Refinerles, 1980-1990 (Thousand Barrels per Stream Day, Except Where Noted)

\begin{tabular}{c|c|c|c|c|c|c|c|c|c}
\hline $\begin{array}{c}\text { As of } \\
\text { January } 1 \\
\text { of Year }\end{array}$ & Number & $\begin{array}{c}\text { Crude } \\
\text { Distillation } \\
\text { (thousand } \\
\text { barrels per } \\
\text { calendar day) }\end{array}$ & $\begin{array}{c}\text { Vacuum } \\
\text { Distillation }\end{array}$ & $\begin{array}{c}\text { Thermal } \\
\text { Cracking }\end{array}$ & $\begin{array}{c}\text { Catalytic } \\
\text { Cracking } \\
\text { Fresh \& } \\
\text { Recycled }\end{array}$ & $\begin{array}{c}\text { Catalytic } \\
\text { Reforming }\end{array}$ & $\begin{array}{c}\text { Catalytic } \\
\text { Hydro- } \\
\text { cracking }\end{array}$ & $\begin{array}{c}\text { Catalytic } \\
\text { Hydro- } \\
\text { treating }\end{array}$ & $\begin{array}{c}\text { Fuels } \\
\text { Solvent } \\
\text { Deasphalting }\end{array}$ \\
\hline & \\
1980 & 319 & 17,988 & 6,381 & 1,564 & 5,773 & 3,970 & 864 & 4,616 & NA \\
1981 & 324 & 18,621 & 7,033 & 1,587 & 6,136 & 4,098 & 909 & 8,487 & NA \\
1982 & 301 & 17,890 & 7,197 & 1,782 & 6,036 & 3,966 & 892 & 8,539 & NA \\
1983 & 258 & 16,859 & 7,180 & 1,715 & 5,890 & 3,918 & 883 & 8,354 & NA \\
1984 & 247 & 16,137 & 7,165 & 1,852 & 5,802 & 3,907 & 952 & 9,009 & NA \\
1985 & 223 & 16,659 & 6,998 & 1,858 & 5,738 & 3,750 & 1,053 & 8,897 & NA \\
1986 & 216 & 15,459 & 6,892 & 1,880 & 5,677 & 3,744 & 1,125 & 8,791 & NA \\
$1987^{a}$ & 219 & 15,566 & 6,935 & 1,928 & 5,716 & 3,805 & 1,189 & 9,083 & 230 \\
1988 & 213 & 15,915 & 7,198 & 2,080 & 5,806 & 3,891 & 1,202 & 9,170 & 240 \\
1989 & 204 & 15,655 & 7,225 & 2,073 & 5,650 & 3,911 & 1,238 & 9,440 & 245 \\
1990 & 205 & 15,572 & 7,245 & 2,108 & 5,755 & 3,896 & 1,282 & 9,537 & 279 \\
\hline
\end{tabular}

a Beginning in 1987, the Hawaiian Independent Refinery is included in U.S. Total.

$N A=$ Not Available.

Source: Form EIA-820, "Annual Refinery Report" and predecessor forms.

9 For explanations of the various types of refinery processes and operations see the Appendix A. 
ing heavy gas oil hydrocarbons, such as fuel oil, into lighter products, such as gasoline. This conversion is done through downstream processing units.

- Very complex refineries have the additional capability to convert (through the use of thermal cracking units) the heaviest hydrocarbons fractions into lighter products, such as motor gasoline.

\section{Number of Refineries}

During the 1980's, the number of operable refineries in the United States declined from 319 to 205. Most of this decline occurred in the number of simple refineries (Table 2). In contrast, most of the large, fully-integrated refineries survived because they were either already equipped to process heavier oils or they had the capital to invest in hydrotreaters, hydrocrackers, and thermal cracking units to process these oils. As the number of operable refineries declined, refiners concentrated on upgrading the capabilities of other processing units which enabled them to produce high-quality light oils. Therefore, expansions to downstream processing capacities improved the overall level of complexity at refineries.

In 1980 , there were 319 operable refineries in the United States, increasing to a historic high of 324 by 1981 . The increase between 1980 and 1981 was a continuation of a growth trend begun in 1977 due to the federally administered Crude Oil Entitlements Program which was implemented in 1974. This progrum was put into effect as a result of Federal Government price controls set in place in the carly 1970's which gave a clear economic advantage to refineries that had access to low-cost domestic oil. The Crude Oil Entitlements Program included features which, in effect, provided a subsidy for small refining companies, many of which had simple tupping facilities with little or no downstream processing capability. A refiner that had light crude oils needed only a distillation tower to produce motor gasoline. Therefore, many simple refineries sprang up across the country, most notably in the Gulf Coast area (Petroleum Administration for Defense (PAD) District III).

However, the end of the Crude Oil Entitlements Program and decontrol of crude oil prices in 1981 eliminated special treatment for small refiners causing many of them to go out of business (Table B1).

Several closings occurred at larger more complex refineries between January 1, 1980, and January 1, 1985, particularly in the Midwest (PAD District II) where a total of 16 complex and very complex refineries were shut down (Table B1 and
Table 2. Number of Refinerles by PAD District on January 1, 1980, 1985, and 1990

\begin{tabular}{c|c|c|c|c}
\hline $\begin{array}{c}\text { PAD District } \\
\text { and Year }\end{array}$ & Simple & Complex & $\begin{array}{c}\text { Very } \\
\text { Complex }\end{array}$ & Total \\
\hline
\end{tabular}

\section{Distrlet I \\ East Coast}

$\begin{array}{lrrrr}1980 & 18 & 10 & 4 & 32 \\ 1985 & 13 & 9 & 4 & 26 \\ 1990 & 11 & 9 & 3 & 23\end{array}$

District II

Midwest

$\begin{array}{lrlll}1980 & 21 & 30 & 23 & 74 \\ 1985 & 11 & 20 & 15 & 46 \\ 1990 & 7 & 16 & 16 & 39\end{array}$

District III

Gulf Coast

1980

1985

$19 \overline{9} 0$

$\begin{array}{lllr}70 & 24 & 27 & 121 \\ 31 & 21 & 26 & 78 \\ 28 & 23 & 24 & 75\end{array}$

Dlstrlct IV

Rocky Mountains

1980

1985

1990

1

11
4
1

17
14
13

$\begin{array}{ll}3 & 31 \\ 4 & 22 \\ 4 & 18\end{array}$

District V

West Coast

1980

1985

1990

37
24
24

12
12
8

$\begin{array}{ll}12 & 61 \\ 15 & 51 \\ 18 & 50\end{array}$

U.S. Total

\begin{tabular}{rrrrr}
1980 & 157 & 93 & 69 & 319 \\
1985 & 83 & 76 & 64 & 223 \\
1990 & 71 & 69 & 65 & 205 \\
\hline
\end{tabular}

Note: Due to reactivations and refinery upgrading and downgrading, which occurred simultaneously with shutdowns, the number of refineries operating in each category is a net number.

Source: Energy Information Administration, Form EIA-820, "Annual Refinery Report," and predecessor forms.

Table B2). All but one of these refineries had been operating for more than 30 years. Included among the total were permanent shutdowns of two very complex refineries in Oklahoma: Champlin Refining at Enid and Tosco's facility at Duncan. These refineries closed in 1983 and 1984, respectively after more than 30 years each of operation. Elsewhere in the Midwest, two other very complex facilities closed: Amoco Oil Company's refinery at Sugar Creck, Missouri, closed in 1982 after 34 years of opcration, and 


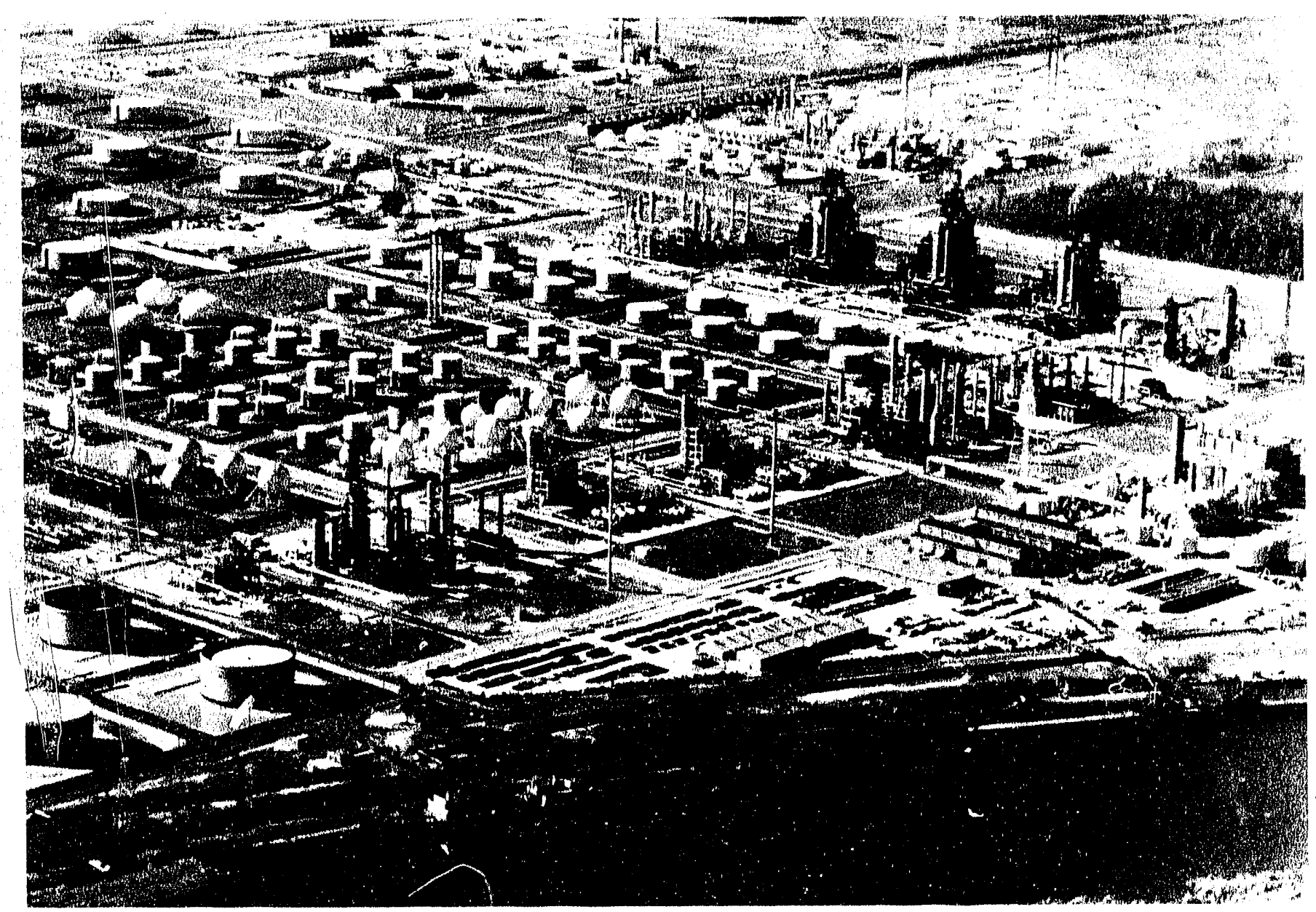

The more complex refineries can process raw materials of varying quality to produce a wider range of petroleum products.

Texaco, Inc., closed its Lockport, Illinois, refinery in 1981 after 33 years of operation.

The closings of older refineries between 1980 and 1985 were due primarily to reduced demand for petroleum products which fell from a record high of 18.8 million barrels per day in 1978 to 15.2 in 1983. Declining demand created excess product inventories and a surplus of crude oil distillation capacity, contributing to a drop in refincry utilization rates from 87.4 percent in 1978 to 68.6 percent in 1981. The combination of declining demand and unfavorable refinery operating rates were major factors leading to reduced refined product margins. In addition, capital investments required to upgrade some old plants were decmed too high. By January 1, 1985, the total number of operable refincries had declined 30 percent.

There were 141 refinery closings between January 1, 1980, and January 1, 1990. Although 49 refineries were reaclivated during this period, only 23 of them remained operable on January 1, 1990 (Table B3). Most of the refineries which opened and subsequently closed again were simple refineries which remained operable for one or two years before being shutdown permanently.

\section{Operable Crude Oil Distillation and Downstream Processing Capacities}

Between January 1, 1980, and January 1, 1990, total U. S. crude oil distillation capacity declined from approximately 18.0 mil ion barrels per calendar day to 15.6 million barrels per calendar day. While operable capacity decreased at simple refineries and complex refineries, operable crude oil distillation capacities increased at very complex refineries during this period. As downstream processing capacitics were upgraded at very complex refineries, additions to crude oil distillation capacitics were also made.

One way the refining industry responds to changes in product demand is by adjusting downstream refinery 
processes to vary the yield of gasoline and other products. In contrast to the large decline in crude oil distillation capacity during the 1980 's, there were significant increases in downstream charge capacity in all but two downstream processes. Catalytic hydrotreating increased by 107 percent between 1980 and 1990; capacities for catalytic hydrocracking grew oy 48 percent; thermal cracking capacities rose 35 percent; vacuum distillation capacity increased 14 percent; and catalytic cracking capacity and reforming capacity showed very little change.

The expansions in downstream processing capabilities were driven by a number of factors. First, refiners upgraded downstream processing capacities to meet the increasing demand for high octane gasoline. Premium unleaded gasoline requires more extensive treatment by complex refinery prosesses than does regular unleaded gasoline. Second, the growing price differential between OPEC and non-OPEC crude oils in the late 1970's and early 1980's prompted refiners to increasingly turn to the less expensive non-OPEC oils, such as crude oils from Mexico and Alaska's North Slope. The heavier, sour oils from these sources require more severe processing to produce high quality motor gasoline blending components. As a result, catalytic hydrocracking and thermal cracking capacities increased substantially, and hydrotreating was added to process high-sulfur crude oil. The added downstream capacity and treatment processes increased the refiners' flexibility in choosing forcign and domestic crude oils.

For example, West Coast refineries significantly increased processing capacitics such as thermal cracking, hydrocracking, and hydrotreating in order to process the heavy Alaskan crude oil these refineries receive. Although the West Coast lost a net total of 11 refineries between 1980 and 1990, hydrotreating capacities increased by about 104 percent. Hydrocracking and thermal cracking capacities in this region increased by 38 percent and 20 percent, respectively.

Hydrocracking increased in importance over the decade because it produces no bottom-of-the-barrel materials, such as coke, pitch, and residuum, which have low value relative to light petroleum products such as motor gasoline. In addition, hydrocracking greatly reduces aromatics (including benzene which has been identified as a potential cause of cancer in humans) in diesel boiling range streams. Complex and very complex refineries substantially increased their catalytic hydrocracking capacity between 1980 and 1990. Refineries on the Gulf Coast increased their hydrocracking capacity by 91 percent.

Thermal cracking charge capacity also grew substantially between 1980 and 1990. Thermal cracking units enable refiners to increase the yicli of lighter products from heavy gas oils and residuum that cannot be processed by other units.

Hydrotreating removes contaminants such as sulfur and metals that would damage the catalyst used in catalytic reforming and catalytic cracking. Total catalytic hydrotreating capacities at U.S. refineries grew by 107 percent between 1980 and 1990, from a level of 4.6 million barrels per stream day to 9.5 million barrels per stream day. This is due primarily to tougher Federal regulations on the maximum allowable sulfur content of diesel fuel oils and a decline in the quality of crude oil.

The catalytic cracking process converts heavy gas oils into high octane gasoline and other light distillates. In 1990, total catalytic cracking capacity (both fresh and recycled) in the United States was 5.8 million barrels per stream day, the same as in 1980. Although the capacity levels did not change during this period, hundreds of new catalysts became available to refiners. Many of these were high-octane catalysts which enabled refiners to generate more volumes of higher octane gasoline. ${ }^{10}$ Some refiners made changes in their hardware to take advantage of these high-octane catalysts. Changes in hardware have focused on regencrator modifications allowing higher combustion efficiency and reduced pollutants emissions, and improvements to feed injection systems. ${ }^{11}$ Catalytic cracking units have proven to be extremely flexible in mecting octane demands while processing lower quality feeds. In very complex refineries, catalytic cracking and hydrocracking have becn integrated to complement each other.

\footnotetext{
10 "U S. Refiners Poised for Move Inio Next Lead Phasedown Step," Oil and Gas Journal (December 23, 1985), p. 17.

11 "Iiluid Catalytic Cracking Report," Oil and Gas Journal (January 8, 1990), p. 55.
} 


\section{Refinery Operations}

\section{Introduction}

In the 1980's, there were significant shifts in the quality of raw materials refineries processed, as well as in the products that they produced. As the decade proceeded, refiners had to contend with crude oils of lesser quality while also contending with market demands for higher quality finished products. The industry that evolved by the end of the decade was leaner, more efficient, and more responsive to changing consumer demand patterns.

\section{Crude Oil and Other Refinery Inputs}

\section{Crude Oil Inputs}

Crude oil is the largest single component of inputs processed by refineries (Figure 2). The quality of crude oil is a very important factor in the operation of a refinery. Crude oil has a variety of properties which affect its quality and value. Sulfur content, expressed as a percentage by weight, and American Petroleum Institute (API) gravity, which is measured in degrees API, are two of the most important properties of crude oil which affect refinery operations.

The sulfur content of crude oil determines the sulfur content of the petroleum products produced. Since the beginning of the 1980's, the weighted average sulfur content of crude oil inputs to U.S. refiners has increased, with most of the increase occurring after 1985 (Figure 3). Increased sulfur content after 1985 reflected the growth in the volume of imported crude oil from the Organization of Petrolcum
Figure 2. Average Refinery Input Composition, 1980-1989

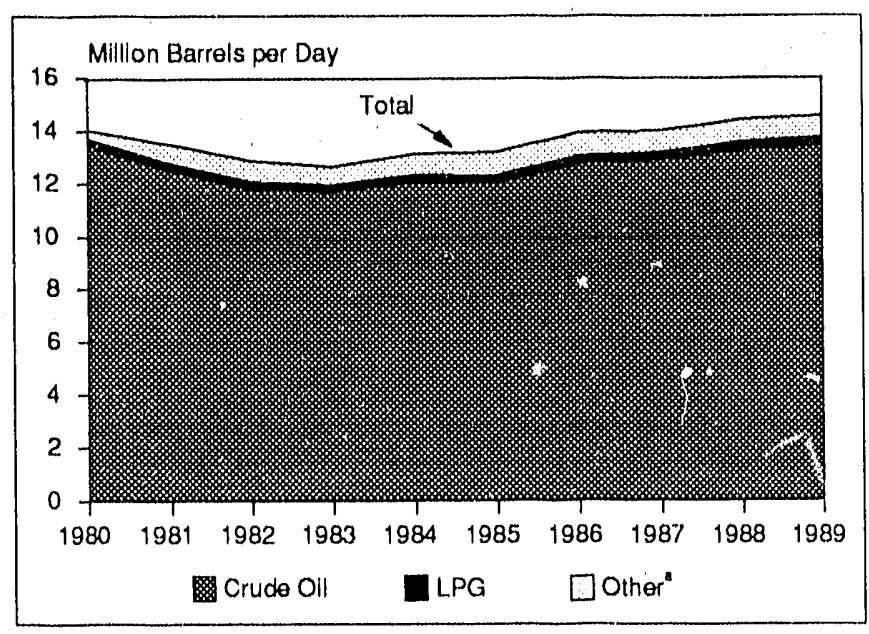

a Other includes natural gas liquids, other hydrocarbons and alcohol, unfinished oils (net), and motor and aviation gasoline blending components (net).

Source: Energy Information Administration, Petroleum Supply Annual, 1989, Volume 1.

See Table C1 in Appendix $C$ for corresponding data.

Exporting Countries (OPEC). OPEC crude oil tends to have a higher sulfur content than crude oil from other sources. ${ }^{12}$

The average API gravity of crude oil inputs to U.S. refinerics has steadily declined throughout the 1980's (Figure 4). The API gravity of crude oil serves as a measure of weight (density) relative to the weight of an equal volume of water, and is expressed in degrees. The API gravity of water is 10 degrees. API gravity provides an indication of the relative amounts (yield) of light and heavy hydrocarbon fractions that can be expected from distilling a given crude oil. Crude oil having a high API gravity contains a rclatively larger volume of light hydrocarbon fractions (gasoline, jet fuel, and distillate fuel oil) than a low API gravity crude oil.

\footnotetext{
12 Encrgy Information Administration, Form EIA-814, "Monthly Imports Report." The overall increase in sulfur content of crude oil was one factor which led refincrs to expand hydrotreating capacity during the 1980 's.
} 
Figure 3. Average Sulfur Content of Crude Oil Inputs, 1981-1989

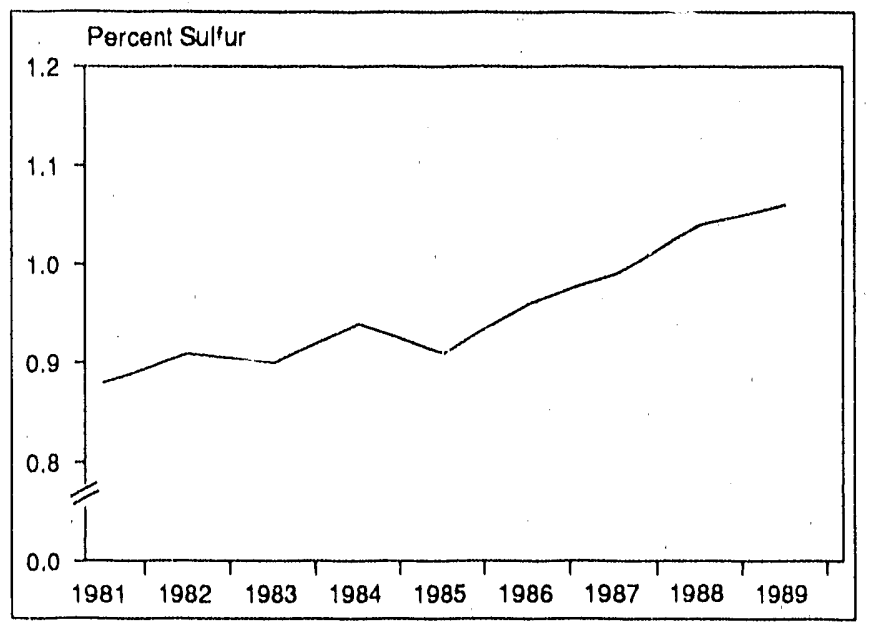

Sources: Energy Information Administration, Poiroleum Supply Annual, 1985-1989, Volume 1; and Petroleum Supply Annual, 1981-1984, Volume 2.

See Table C2 in Appendix C for corresponding data.

Because lighter hydrocarbon fractions generally make up higher value products, demand is strong for crude oils having high API gravities.

Decreases in the average API gravity of crude oil have contributed to the importance of processes which upgrade heavy fractions. Extensive use of upgrading processes allowed U.S. refiners to increase, or at least maintain, yields of high value light products when API gravity of crude oil inputs were generally decreasing.
Figure 4. Average API Gravity of Crude OII Inputs, 1981-1989

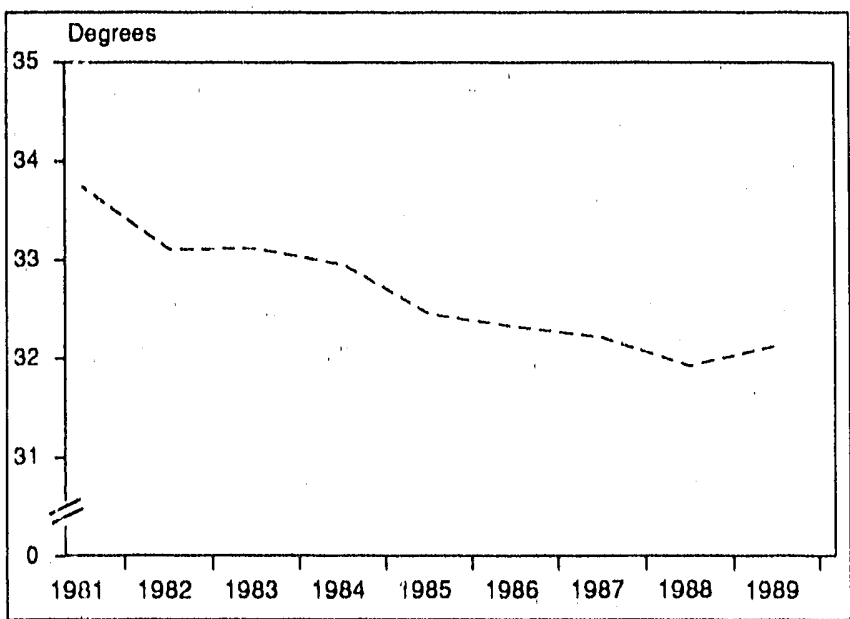

Sources: Energy Information Administration, Petroleum Supply Annual, 1985-1989, Volume 1; and Petroleum Supply Annual, 1981-1984, Volume 2.

See Table C3 in Appendix $\mathrm{C}$ for corresponding data.

\section{Natural Gas Liquids Inputs}

Inputs of natural gas liquids (NGLs) include liquefied petrolcum gases (LPGs) and pentanes plus (Table 3). Most of the LPG inputs to refineries are butanes for blending into gasoline or for use as alkylation unit feedstocks. Inputs of pentanes plus include pentanes, hexanes, and heavier hydrocarbons which are also used primarily for blending into gasoline. The large reduction in LPG inputs in 1983 resulted from a general slowdown in refinery operations

Table 3. Average Re.inery Inputs of Natural Gas Liquids and Other Liquids, 1980-1989 (Thousand Barrels per Day)

\begin{tabular}{|c|c|c|c|c|c|c|}
\hline \multirow[b]{2}{*}{ Year } & \multicolumn{3}{|c|}{ Natural Gas Liquids } & \multirow{2}{*}{$\begin{array}{l}\text { Unfinished } \\
\text { Oils }\end{array}$} & \multirow{2}{*}{$\begin{array}{c}\text { Gasoline } \\
\text { Blending } \\
\text { Components }\end{array}$} & \multirow{2}{*}{$\begin{array}{c}\text { Other } \\
\text { Hydrocarbons } \\
\text { and Alcohol }\end{array}$} \\
\hline & LPG & Pentanes Plus & Total & & & \\
\hline 1980 & 233 & 229 & 462 & 38 & NA & 44 \\
\hline 1981 & 289 & 234 & 524 & 286 & 152 & 50 \\
\hline 1982 & 300 & 215 & 515 & 349 & 170 & 52 \\
\hline 1983 & 253 & 206 & 460 & 318 & 134 & 53 \\
\hline 1984 & 291 & 209 & 500 & 421 & 115 & 45 \\
\hline 1985 & 304 & 205 & 509 & 441 & 185 & 55 \\
\hline 1986 & 302 & 177 & 479 & 451 & 203 & 58 \\
\hline 1987 & 304 & 162 & 466 & 472 & 131 & 64 \\
\hline 1988 & 321 & 189 & 511 & 471 & 85 & 53 \\
\hline 1989 & 315 & 184 & 499 & 511 & 42 & 60 \\
\hline
\end{tabular}

$N A=$ Not Available

Sources: Energy Information Administration, Petroleum Supply Annual, 1981-1989, Volume 1; and Energy Information Administration, Energy Data Reports, "Crude Petroleum, Petroleum Products, and Natural Gas Liquids: 1980," Table 15, p. 21. 
brought about by low demand for petroleum products an' a sharp increase in the price of LPG feedstocks. The moderate reduction of inputs of LPGs from 1988 to 1989 reflects removal of some normal butane from the gasoline pool to comply with environmental regulations mandating reductions in gasoline vapor pressure during the summer months.

\section{Unfinished Oils}

Unfinished oils include naphthas and lighter oils, kerosene and light gas oils, heavy gas oils, and residuum. These oils represent intermediate (unfinished) products that require further processing, generally in downstream processing units.

Simple refineries do not heve downstream processing capacity to upgrade their unf nished oils into light products. By shipping unfinished oi's to complex and very complex refineries, the value of heavy products produced at simple refincries is increased through downstream processing.

During the 1980's, downstream unit capacitics have increased substantially while atmospheric crude oil distillation capacity declined. Most unfinished oils are produced from distilling crude oil. As crude oil distillation capacity declined during the 1980's, it became necessary for complex and very complex refiners to look beyond the refinery gate for unfinished oil supplies needed as inputs to downstream units. This led to growth in imports of unfinished oils.

\section{Other Hydrocarbons and Alcohol}

Other hydrocarbons and alcohol include hydrogen, alcohols (i.e., methanol, ethanol, tertiary butyl alcohol (TBA)), and methyl tertiary butyl ether (MTBE). Alcohols and MTBE are blended into motor gasoline to boost unleaded motor fuel octane ratings. The hydrogen component of other hydrocarbons and alcohol is uscd primarily in hydrotreating and hydrocracking processes.

The oxygenate that was widely used for gasoline blending during the 1980's was MTBE. Production of MTBE is accomplished through a chemical process which combines methanol, which is derived primarily from natural gas, and isobutylene. MTBE was used during the late 1980's as a primary component of several reformulated unleaded gasolines which were intended for use in vehicles designed to run on leaded gasoline. Advantages of MTBE blending into gasoline include octane enhancement, low vapor pressure, and an increase in motor gasoline volume without additional inputs of crude oil.
The petroleum industry has accepted MTBE as a component of motor gasolines because it is compatible with existing transportation and processing infrastructure. In addition, MTBE can be used in currently available automobile cngines. Widespread use of alcohol additives for motor gasoline has been resisted secause of requirements for new or modified equipment to handle fuels contaiaing alcohols and because some redesign of automobile engines would be required. The need for new infrastructure to process and transport alcohol blend gasoline is due largely to the problem of alcohol phase separation in the presence of water. If water comes into contact with a gasoline containing alcohol, the alcohol may become dissociated from the gasoline and mix with the water. This phenomenon creates problems for pipelines, which are generally not designed to completely exclude water, and also for marketers and purchasers of gasolines who may find their fucl quality degraded by interaction with water.

\section{Capacity Utilization}

The most common gauge used to measure the efficiency of refinery operations is the utilization rate of the atmospheric crude oil distillation units. The decade of the 1980's was good for U.S. refineries, as the industry's average utilization rate increased each year after 1980 (Figure 5). During the first part of the 1980's, utilization rates increased because of reductions in distillation capacity due to the closing of refincries. Since 1985, increased inputs, to kecp up with increasing product demand, has been the primary reason for higher utilization rates.

Figure 5. Average Operable Refinery Utilization Rate, 1980-1989

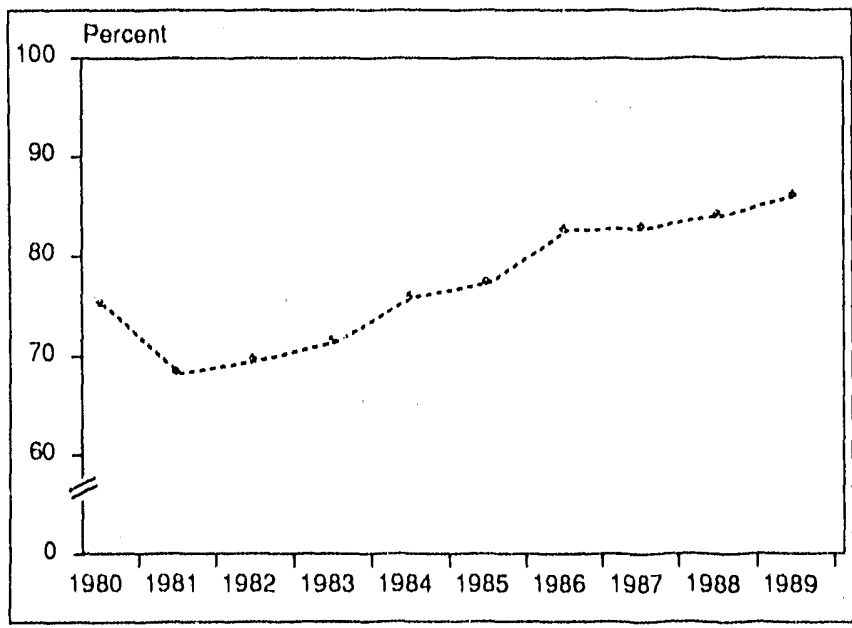

Sources: Energy Information Administration, Annual Energy Review 1988; and Petroleum Supply Annual 1988 and 1989, Volume 1.

See Table $\mathrm{C} 4$ in Appendix $\mathrm{C}$ for corresponding data. 


\section{Refinery Yields}

Refinery yiclds represent the amount (expressed as a percent) of the various petroleum products produced from a barrel of crude oil. Light-end products (motor gasoline, aviation gasoline, still gas, and liquefied petroleum gases) consistently account for more than half of the U. S. refinery yields, while mid-range products (jet fuel, kerosene, petrochemical feedstocks, distillate fuel oil, special naphtha, and miscellaneous products) constitute about one-third, and heavy-range products (residual fuel oil, lubricants, waxes, petrolcum coke, and asphal//road oil) account for the remainder. Yields of light-end products in the United States increased between 1980 and 1985, while yields of heavier products declined (Figure 6 ).

Product yields differ among simple, complex, and very complex refineries (Table 4). Yields of light-end products at simple refineries, limited by the lack of cracking capacity, have always been well below those for complex and very complex refinerics. As the quality of crude oil input to refincrics deteriorated during the 1980's, the portion of light-end products produced at simple retineries declined by 11.8 percentage points between 1981 and 1989 . Over the same period, mid-range product and heavy product yields grew significantly.

\section{Figure 6. Annual Ylelds of Finished Products}

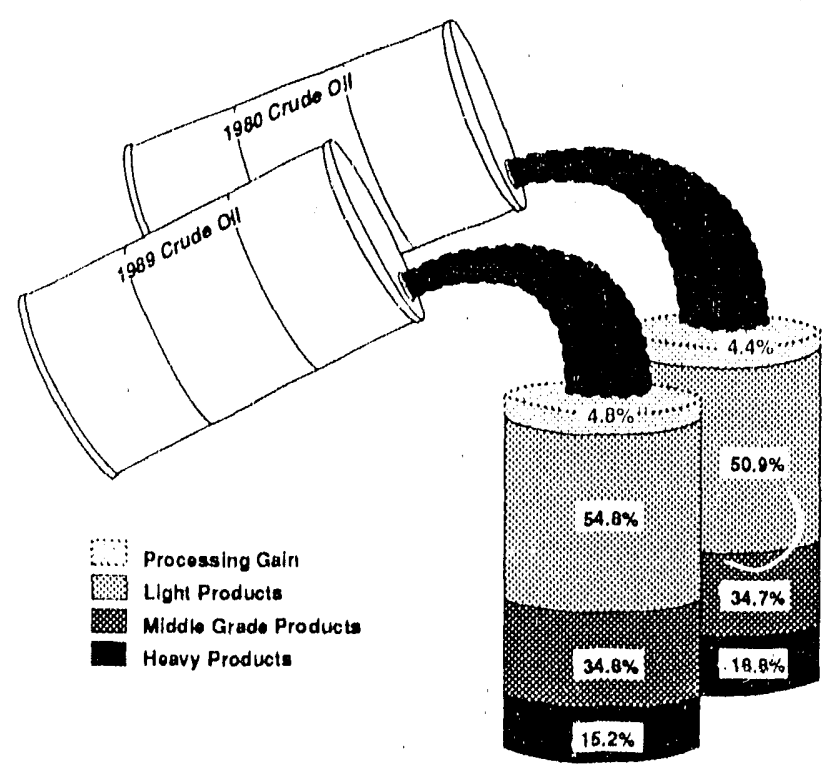

Note: Totals may not equal sum of components due to independent rounding.

Source: Energy Information Administration, Office of Oil and Gas.
Table 4. Refinery Yields by Refinery Type and Product Type, 1981,1985 , and 1989 (Percent)

\begin{tabular}{|c|c|c|c|}
\hline $\begin{array}{c}\text { Refinery/ } \\
\text { Product Type }\end{array}$ & 1981 & 1985 & 1989 \\
\hline \multicolumn{4}{|l|}{ Simple } \\
\hline Light ..................... & 26.5 & 24.3 & 14.7 \\
\hline Middle .................... & 44.9 & 43.2 & 48.9 \\
\hline Heavy ..................... & 30.3 & 32.7 & 35.6 \\
\hline \multicolumn{4}{|l|}{ Complex } \\
\hline Light ..................... & 52.5 & 53.4 & 54.3 \\
\hline Middle .................... & 31.4 & 33.2 & 32.3 \\
\hline Heavy .................. & 19.4 & 17.2 & 17.3 \\
\hline \multicolumn{4}{|l|}{ Very Complex } \\
\hline Light ..................... & 56.5 & 56.8 & 57.9 \\
\hline Middle ................. & 35.2 & 36.3 & 35.1 \\
\hline 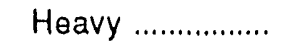 & 13.8 & 12.2 & 12.4 \\
\hline
\end{tabular}

a Light products include motor gasoline, aviation gasoline, liquefied refinery gases, and still gas. Middle grade products include jet fuei, kerosene, petrochemical feedstocks, distillate fuel oil, special naphthas, and miscellaneous products. Heavy products include residual fuel oil, lubricants, waxes, coke, and asphaltroad oil.

Note: Production data by refinery type are not available prior to 1981. Yields are greater than 100 percent because of processing gain.

Source: Energy Information Administration, Petroleum Supply Division, Integrated Petroleum Supply Data Base.

\section{Yields of Individual Products}

Refineries operate in a gasoline mode or a distillate mode, depending on the season. During the spring and summer, the gasoline mode is in operation to produce motor gasoline and oils used for highway repair. In the fall and winter, the distillate mode is operating to maximize production of heating fucls.

Motor gasoline, residual fuel oil, and kerosene-type jet fucl showed the largest changes in refinery yields during the 1980's (Figure 7).

\section{Motor Gasoline}

The most significant change in refinery yiclds during the 1980's was between leaded and unleaded motor gasoline (Figure 8). Less than half of the motor gasoline production at refineries was unleaded at the beginning of the decade. By 1989 , yields of unleaded gasoline represented 89 pereent of the total motor gasoline yickss. The introduction of the catalytic converter to reduce toxic tailpipe emissions from automobiles in the carly 1970's directly increased the demand for unleaded motor gasoline. As the vehicle flect 


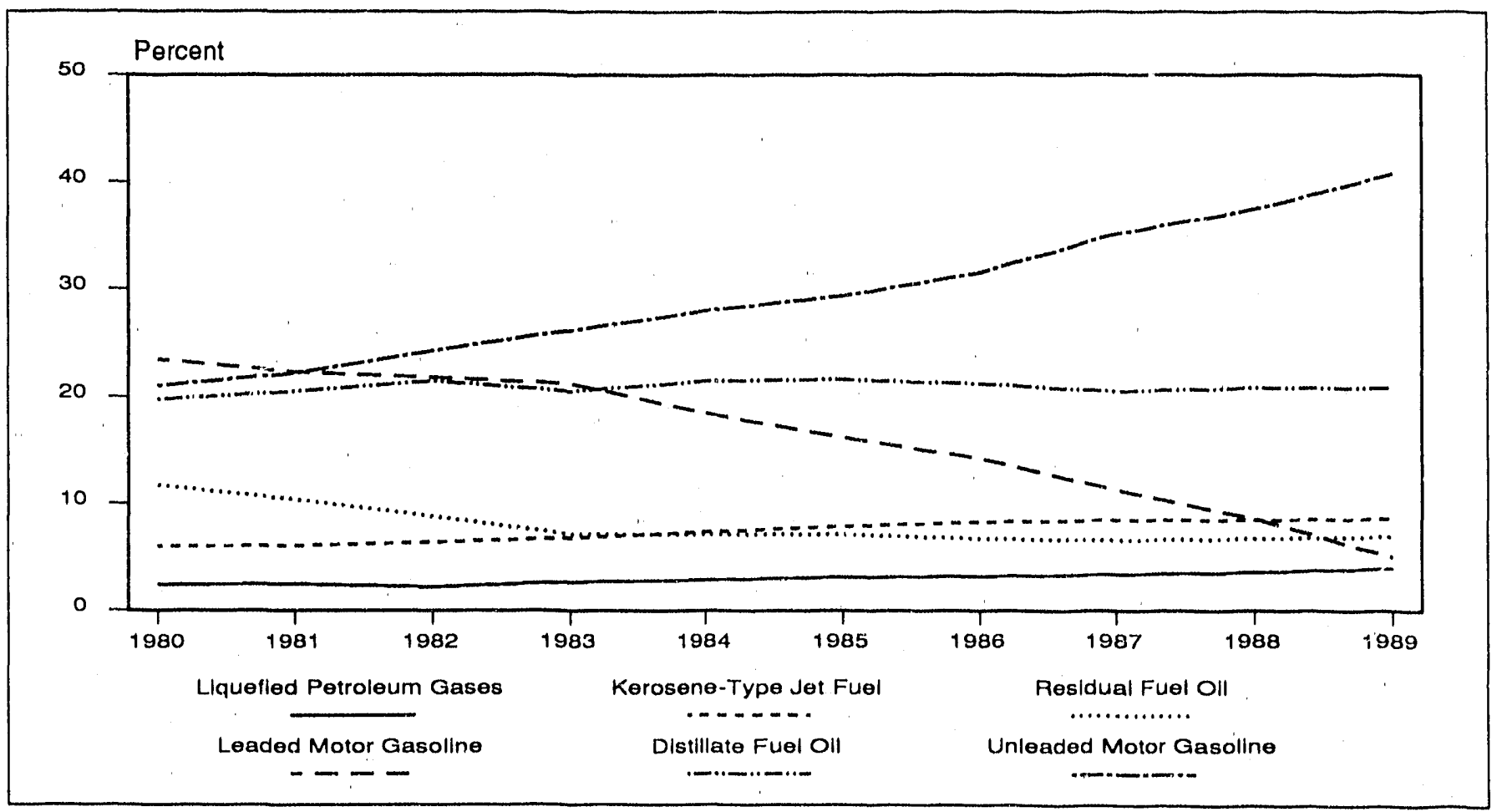

Sources: Energy Information Administration, Petroleum Supply Annual'1981-1989; and Energy Data Reports, "Crude Petroleum, Petroleum Products, and Natural Gas Liquids: 1980."

See Table C5 in Appendix C for corresponding data.

Figure 8. Motor Gasoline Ylelds, 1980-1989

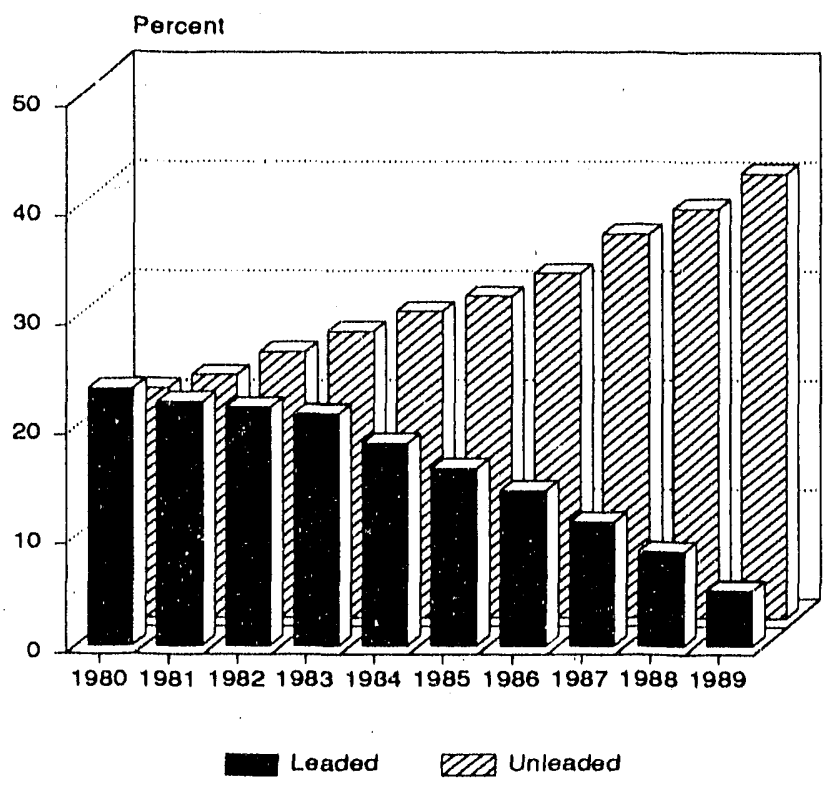

Sources: Energy Information Administration, Petroleum Supply Annual 1981-1989; and Energy Data Reports, "Crude Petroleum. Petroleum Products, and Natural Gas Liquids: 1980."

See Table C6 in Appendix C for corresponding data. with catalytic converters grew, refineries had to increase production of unleaded gasoline.

Refiners were also required to reduce the amount of lead in gasoline during the 1980's. The EPA determined that the allowable lead in gasoline could be greatly reduced and still provide quality performance in automobiles requiring lead. Consequently, in March 1985, the EPA announced a series of regulations that reduced the allowable lead content in gasoline from 1.1 gram per gallon to 0.1 gram per gallon by January $1,1986$.

\section{Residual Fuel Oil}

Yields of residual fuel oil declined from 11.7 percent in 1980 to 6.6 percent in 1987 , before increasing slightly in 1988 and 1989. Changes in Federal regulations had major impacts on the decline in demand and, consequently, refinery yiclds of residual fuel oil. After petroleum prices were decontrolled in January 1981, residual fuel oil produced in the United States was no longer competitive with bunker fuel from forcign suppliers, and refinery yiclds began a downward trend that lasted through 1987. 


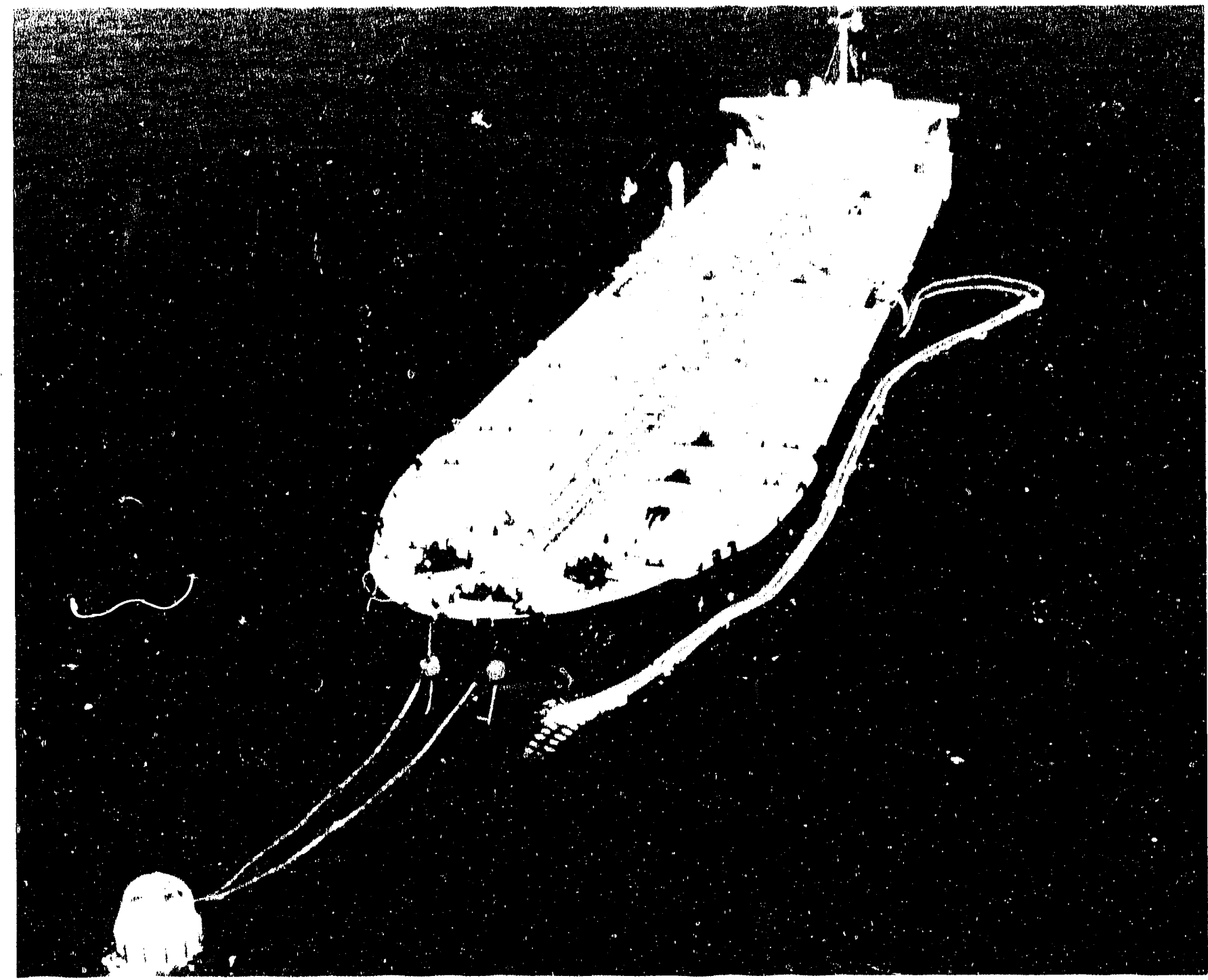

A very large crude oil carrier is moored to a single point buoy system of the Lovisiana Offshore Oil Port (LOOP), discharging crude oil from abroad through flexible, floating hoses in the Gulf of Mexico, 18 miles off the Louisiana coast.

An additional disinecntive to refinery production of residual fuel oil was caused by the Power Plant and Industrial Fuel Use Act of 1978 , which restricted the construction of power plants that use petroleum or natural gas as a primary energy source. Consequently, most new power plants coming on line during the 1980's were designed to use coal or nuclear power as the primary fuel. Though the Act was repealed in 1987, its impact on residual fuel oil demand was felt through the end of the decade.

\section{Kerosene-Type Jet Fuel}

Yiclds of kerosene-type jet fuel increased steadily, from 6.() percent of total finished product yiclds in 1980 to 8.6 pereent in 1989. The Federal deregulation of airlines in 1978 spawned many new airlines by 1981 , causing an increase in airline competition which resulted in an escalation in discount fares in the United States. Price competition among airlines continued into the mid-1980's. The result of all these fores was a dramatic increase in kerosene-type jed luel denand, which hit new records each year since 1984.

\section{Crude Oil Storage Capacity and Inventory}

Storage capacity for crude oil al U.S. refineries declined by 13 million barrels between January 1, 1983, and January 1, 1985, when a large number of refineries were being shutdown (Table 5). Reductions in crude oil storage capacity 
Table 5. Refinery Storage Capacity, ${ }^{\text {a }}$ Crude Oll and Refined Petroleum Products, 1980-1990 (Million Barrels)

\begin{tabular}{|c|c|c|c|c|c|c|c|}
\hline $\begin{array}{c}\text { As of } \\
\text { January } 1 \\
\text { of Year }\end{array}$ & $\begin{array}{c}\text { Crude } \\
\text { Oill }\end{array}$ & $\begin{array}{c}\text { Total } \\
\text { Gasoline } \\
\end{array}$ & $\begin{array}{c}\text { Middle } \\
\text { Distillate }\end{array}$ & $\begin{array}{l}\text { Residual } \\
\text { Fuel Oil }\end{array}$ & Jet Fuel & Other & Total Products \\
\hline 1980 & 203 & 145 & 119 & 70 & 30 & NC & NC \\
\hline 1981 & 212 & 191 & 119 & 77 & 31 & NC & NC \\
\hline 1982 & 211 & 192 & 120 & 71 & 31 & NC & NC \\
\hline 1983 & $2 ? 0$ & 204 & 120 & 69 & 35 & 272 & 700 \\
\hline 1984 & 214 & 198 & 113 & 62 & 37 & 282 & 691 \\
\hline 1985 & 207 & 204 & 119 & 65 & 39 & 277 & 704 \\
\hline 1986 & 207 & 218 & 121 & 66 & 41 & 290 & 735 \\
\hline 1987 & 206 & 212 & 115 & 61 & 41 & 286 & 716 \\
\hline 1988 & 215 & 202 & 111 & 62 & 40 & 306 & 721 \\
\hline 1989 & 204 & 202 & 115 & 57 & 42 & 316 & 732 \\
\hline 1990 & 204 & 202 & 111 & 56 & 43 & 320 & 733 \\
\hline
\end{tabular}

a Represents shell storage capacity (which is the design capacity of the tank) as of January 1.

$\mathrm{NC}=$ Not Comparable; collection of consistent data on petroleum products storage capacity for other products began with January $1 ; 1983$.

Sources: Energy Information Administration, Petroleum Supply Annual Volume 1, 1981-1989; Energy Data Report, "Petroleum Refineries in the United States and U.S. Territories, 1980," p. 38; and Energy Data Report, "Petroleum Reineries in the United States and U.S. Territories, $1981, "$ p. 35.

also reflected the industry trend toward lower stock levels and more efficient use of available storage capacity. ${ }^{13}$

Crude oil stock levels generally declined between 1980 and 1985, the result of refinery closures, decreasing product demand, high interest rates, and reductions in waterborne imports (Figure 9). In addition, high crude oil stocks exposed refiners to financial risks during periods of crude oil price volatility. To achieve lower stock levels, refiners relied on sophisticated inventory management practices including changes in delivery schedules and use of sophisticated crude oil trading mechanisms. ${ }^{14}$ An example of a crude oil trading mechanism is the quality trade. A quality trade involves a tranisfer of high quality crude oil from a complex or very cornplex refinery to a simple refinery in exchange for a larger volume of low quality crude oil.

During 1986, crude oil stocks at refineries increased for the first time since 1983. Although refiners continued to use inventory management to keep stock levels down, growth in waterborne crude oil imports, which are not as reliable as pipelines, influcriced refiners to maintain higher crude oil stock levels. As crude oil stock levels grew in 1986, the combination of higher prices and possible supply disruptions led U.S. refiners to buildup crude oll storage capacity during 1987. Crude oil stocks tend to increase when prices rise or are expected to rise, or when the threat of supply disruptions is perceived to be high. During the first 3 quarters of 1987, refinery acquisition costs for crude oil generally increased, leading to expectations of higher prices in the future. In addition, the possibility of disruptions in

\section{Figure 9. Year-End Refinery Stocks of Crude Oll, 1980-1989}

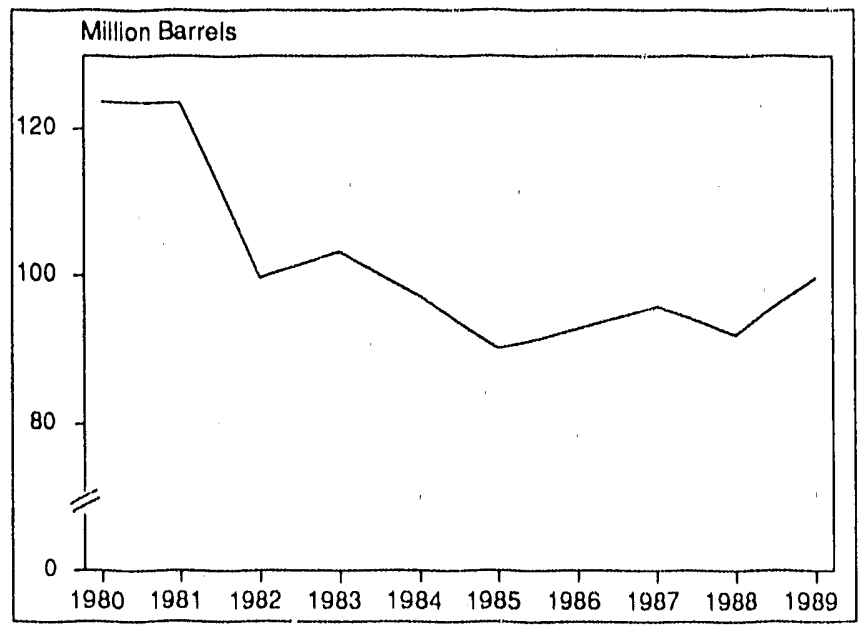

Note: Stock levels are as of December 31.

Sources: Energy Information Administration, Petroleum Supply Annual, Volume 1, 1981-1989; and Energy Data Reports, "Crude Petroleum, Petroleum Products, and Natural Gas Liquids: 1980," Table 12, p. 18.

\footnotetext{
${ }^{13}$ National Petroleum Council 1989, Petroleum Storage and Transportation, Volume IV, p. 45, Washington, DC.

14 Obel, Michael, "Refiners Mecting U.S. Demand With Less Product In Inventory," Oil and Gas Journal (February 17, 1986), p. 19.
} 
crude oil shipments from the Persian Gulf was high during 1987 because of events associated with the Iran-Iraq War. All these factors led to significant additions to crude oil storage capacity during 1987. As of January 1, 1988, crude oil storage capacity at refineries was 9 million barrels higher than it had been on January 1, 1987, representing the first crude oil storage capacity increase since 1983.

By the end of 1987, the incentive to increase crude oil stocks was largely gone as tensions in the Persian Gulf region abated and prices began to fall. This led to reduced crude oil inventories and the removal of crude oil storage capacity at refineries. By January 1, 1989, crude oil storage capacity at refineries fell to the lowest level since January 1, 1982.

\section{Petroleum Products}

Total storage capacity for petroleum products at U.S. refineries fluctuated between 691 and 735 million barrels between January 1, 1983, and January 1, 1090.15 Motor gasoline was the largest single component of the total increase in storage capacity, and it, along with unfinished oils were the largest contributors to fluctuations in inventory levels of total preducts during the decade.

End of year refinery stocks of petroleum products fell significantly between 1980 and 1984 (Figure 10). Reductions in product stocks were, like crude oil, in response to high carrying costs, including high interest rates and declining demand. By lowering product inventories, refiners also avoided the financial risks associated with high stock volumes at a time when crude oil price fluctuations could cause product prices to fall rapidly. Price flucluations over short time spans were common in the late 1980's as the volume of crude oil and products sold on the spot market increased. Increased product trading and spot market pur chases were among the measures taken by refincrs to satisfy product demand while lowering inventoriss. Refiners also began holding higher crude oil stocks relative to product demand. This allowed demand surges to be met through additional production rather than through product stock drawdowns. ${ }^{16}$

Beginning in 1985, petroleum product stock levels at refineries stabilized and even increased slightly. Higher demand and reductions in storage costs led refiners to maintain higher petroleum product stocks in the late 1980 's. ${ }^{17}$ Product stock leveis did not, however, return to the high levels of the early 1980's because of continued inventory management practices which allowed lower product stock levels and helped to control storage costs.

Increased stocks of motor gasoline and unfinished oils accounted for most of the overall growth in refinery stocks of petroleum products after 1984. Higher motor gasoline stocks reflected increased refinery production to meet rising demand in the late 1980's. Levels of unfinished oils stocks were increased to ensure a continuous supply of inputs to downstream units in the event of a disruption in feedstock supplies.

\section{Refinery Fuel Use}

While the petrolcum refining industry made significant gains in energy efficiency during the 1980 's, ${ }^{18}$ growth in downstream processing led to increased refinery fuel use

\section{Figure 10. Refinery Stocks of Petroleum Products, 1980-1989}

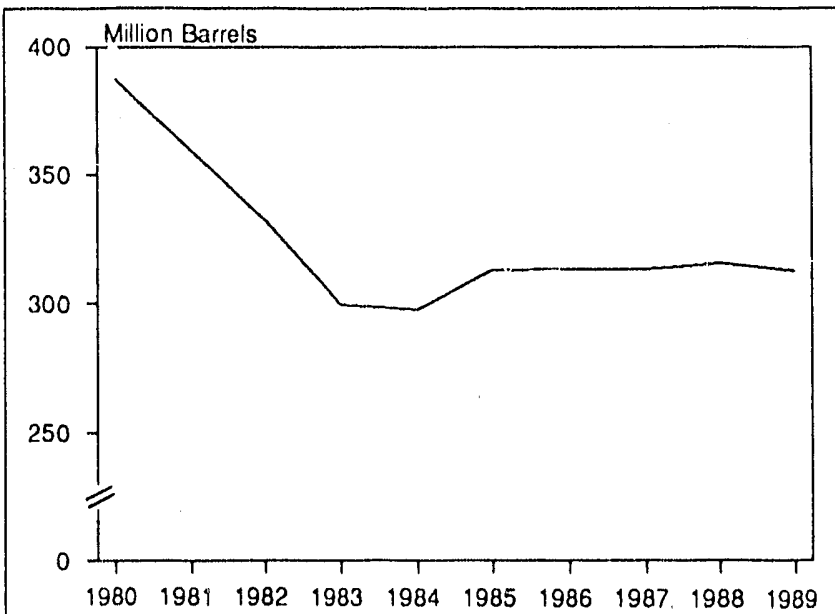

Note: Stock levels are as of December 31

Sources: Energy Information Adminstration, Energy Data Reports, "Crude Petroleum, Petroleum Products, and Natural Gas Liquids: 1980," Table 18, p. 24; and Petroleum Supply Annual, Volume 1, $1981-1989$.

See Table C8 in Appendix C for corresponding data.

\footnotetext{
15 Data on refined product storage capacity prior to 1983 are not comparable with later storage capacity data.

16 Obel, Michael, "Refiners Meeting U.S. Demand W'ith Less Product In Inventory," Oil and Gas Journal (February 17, 1986), pp. 19-21.$$
18
$$ 
during the last half of the decade. Refinery consumption of petroleum fucls, natural gas, and electric power have all increased since 1985 (Figures 11, 12, and 13). Coal consumption declined during the 1980 's because most of the

Figure 11. Petrolem Fuel Use at Refinerles, 1980-1989

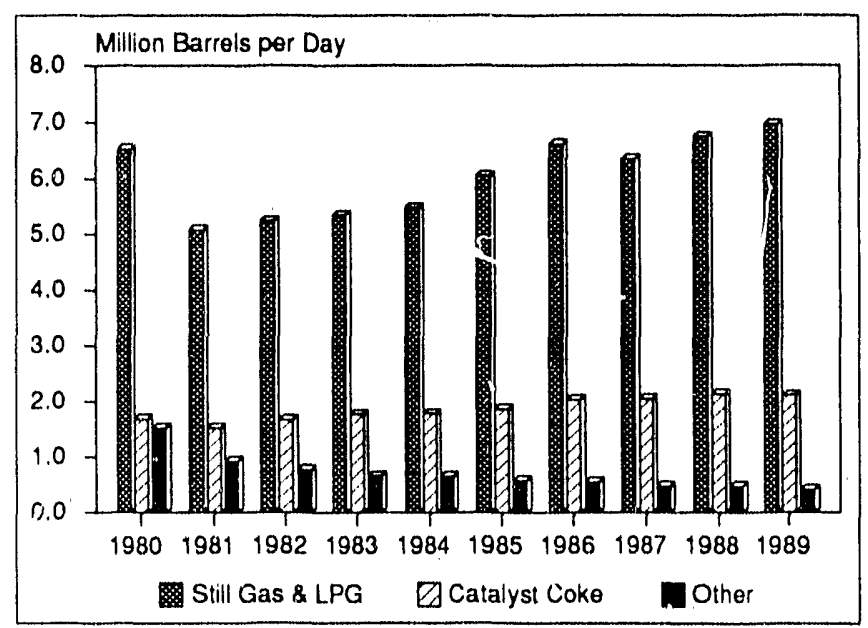

Source: Energy Information Administration, Petroleum Supply Annual, Volume 1, 1983-1989; Petroleum Supply Annual, Volume 2, $1981-1982$.

See Table C9 in Appendix C for corresponding data.

Figure 12. Natural Gas Use at Refinerles, 1980-1989

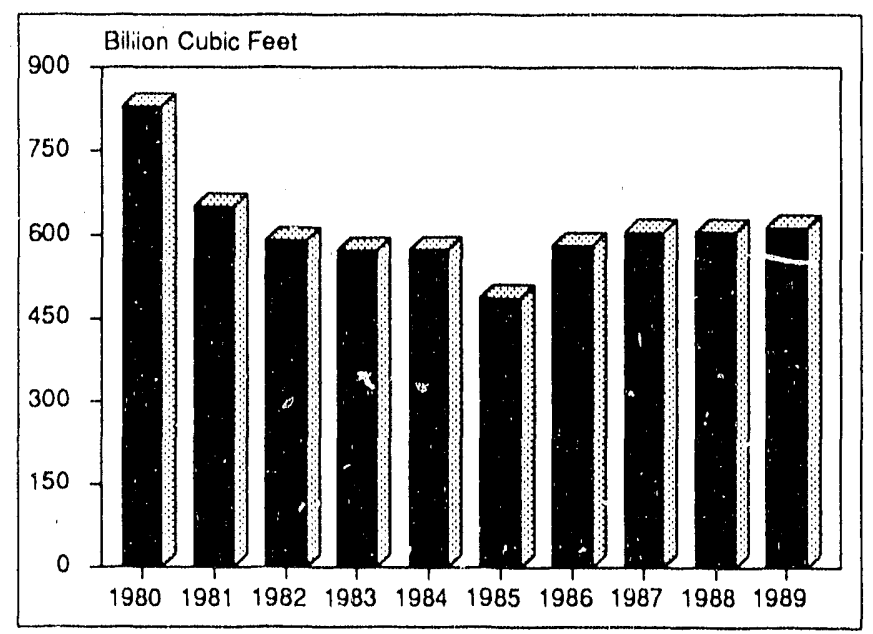

Source: Enargy Information Administration, Petroleum Supply Annual, Volume 1, 1983-1989; Petroleum Supply Annual, Volume 2. $1981-1982$

See Table C 10 in Appendix C for corresponding data.
Figure 13. Purchased Electricity Use at Refineries, 1980-1989

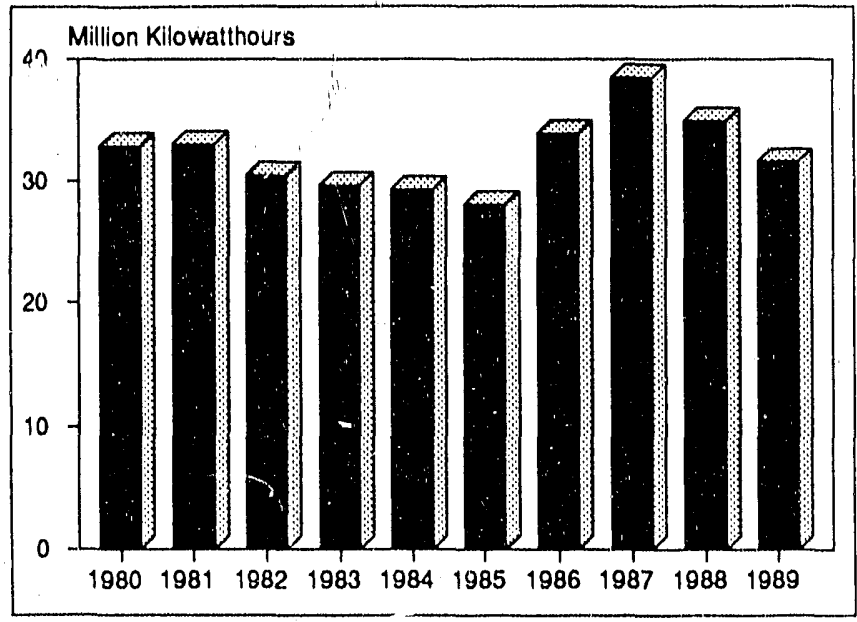

Source: Energy Information Administration, Petroleum Supply Annual, Volume 1, 1983-1989; Petroleum Supply Annual, Volume 2. 1981-1982.

See Table C11 in Appendix C for corresponding data.

refineries using coal closed during the early part of the decade (Figure 14).

Refinery consumption ci petrolcum and natural gas followed the same general pattern as in other industrics. The large drop in natural gas fuel use followed 10 consecutive years in which annual average natural gas prices to the industrial sector increased.

Still gas and catalytic coke composed the largest components 0 : petroleum fuel use at refineries during the 1980 's. Since these fuels are by-products of refining processes, they are an attractive source of energy for refiners. Refinery production of catalyst coke has grown during the 1980's with increased catalytic cracking activity.

Downstream refining processes use large amounts of electric power. ${ }^{19}$ The growing importance of downstream processes in mecting demand for light products led to substantial growth in refinery consumption of purchased clectricity from 1985 to 1987 . During 1988 and 1989. refinery use of purchased electricity declined. Most of the decline was in the West Coast (PAD District V) where cogeneration activity was especially strong within the petroleum industry. ${ }^{20}$

\footnotetext{
19 "U.S. Cogeneration Faces More Slow Growth, Consolidation, Competition," Oil and Cas Journal (June 12, 1989 ), p. 17.

20 "U.S. Cegeneration Faces More Slow Growth, Consolidation, Competitior," Oil and Gas Journal (June 12, 1989$)$, p. 17.
} 
Figure 14. Coal Use at Refineries, 1982-1989

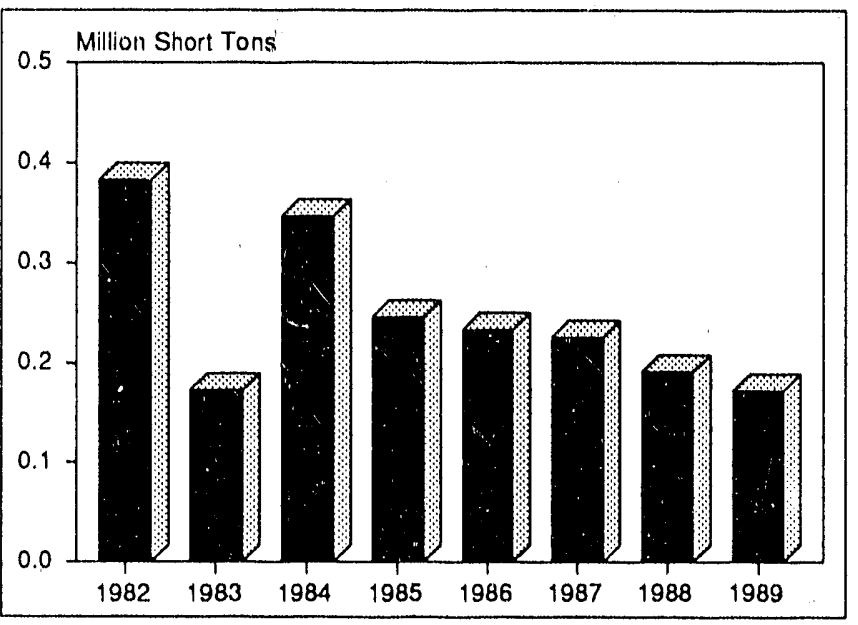

Source: Energy Information Administration, Petroleum Supply Annual, Volume 1, 1983-1989; Petroleum Supply Annual, Volume 2, 1981-1982.

Note: Comparable data are not available prior to 1982.

See Table C12 in Appendix C for corresponding data.

\section{Advances in Refining Technology}

Refining technology improved during the 1980's as refiners sought to improve their capabilities for producing high value light products which would satisfy demand for petroleum products and also meet increasingly restrictive cnvironmental regulations. Many refiners expanded capital investments in existing technologies for conversion, reforming and isomerization, and desulfurization. Octane cnhancing catalysts and new applications of advanced computer technology for process control and refinery operations management were major innovations in refining during the 1980 's.

\section{Octane Catalysts}

During the early 1980's, the primary objective of refiners was io enhance the yield of motor gasoline due to growth in unleaded motor gasoline demand and rising crude oil prices. One method used by refiners to achieve higher yields was through widespread use of zeolite catalysts in fluid catalytic cracking units (FCCUs). ${ }^{21}$ Increased yiclds werc achieved at the expense of lower octane numbers in naphthas produced from FCCUs. ${ }^{22}$

During the last half of the 1980's, octane enhancement joined yield enhancement as a major focus for refiners. The need for increased motor gasoline yields and octane numbers resulted from a combination of growth in consumer demand for high octane fuels and environmental regulations which resulted in further removal of tetracthyl lead from the gasoline pool. In order to boost the octane rating of naphthas produced from FCCUs, a variety of octane catalysts were introduced during the mid-1980's. ${ }^{23}$ Octane catalysts provided an attractive method for refiners to boost gasoline octane numbers because naphtha from FCCUs accounts for approximately 35 percent of the motor gasoline pool. ${ }^{24}$ In some refineries, the volume of naphtha from FCCUs may account for over 50 percent of the total volume of gasoline produced. In this case, an increase of 2 octane numbers in the FCCU naphtha would raise the octane rating of all gasoline produced by 1 full number.

\section{Applications of Computers}

Refinery processing and blending operations are characterized by a high degree of automation and complexity with requirements for precise control of parameters such as pressure, temperature, and feed rates, as well as formulas used in product blending. In addition to actual processing, refiners must acquire crude oil and other raw materials, ship finished products, and manage inventories. These activitics require detailed and timely information relating to international petroleum markets and unit operating conditions to ensure that profits are maximizied. The nature of refinery operations has made the refining industry heavily dependent on computers for decades, but the use of computers increased in the 1980's due to requirements for tighter control of product formulations, compliance with environmental regulations, and the general increase in competition within the industry.

Refinery processing and blending operations involve planning, scheduling, optimization, and control. The ability of

\footnotetext{
21 Catalytic cracking is a downstream refinery process by which iarge, heavy hydrocarbon molecules are broken down, or cracked into smaller, gasoline range hydrocarbon molecules.

22

. Catalytic Cracking Report, Oil and Gas Journal (January 8, 1990), p. 54.

23 "U.S. Refiners Poised For Move Into Next Lead Phasedown Step," Oil and Gas Journal (December 23, 1985), p. 18.

24 "Fluid Catalytic Cracking Report," Oil and Gas Journal (January 8, 1990), p. 54.
} 
refinery managers and engineers to perform each of these functions has been enhanced by application of computers. ${ }^{25}$

Strategic planners use linear programming models to determine how refinery precessing and blending operations should be carried out. Factors considerd by these planners include expected unit performance, quality and availability of crude nil, and demand for petroleum products. Normally, strategic planning functions are performed weeks or months in advance of actual processing and blending operations.

Scheduling generally has a lead time of one week or less and involves developing detailed processing and blending schedules to meet the objectives set out in longer range planning. Scheduling requires adjustments to original plans to account for unexpected changes in unit operations and market conditions. The focus of scheduling activity has historically been on developing feasible solutions to processing plans, but advances in computer and modeling technology have made optimization a part of the scheduling process.

Operating specifications for refinery processing and blending functions are established during the optimization phase of refinery operations planning. Offline optimization has traditionally been a daily function, but application of computers has shortened the lead time to 1 to 2 hours. Operating specifications determined in the optimization phase define the limits on adjustments which may be made in controlling refincry processes.

Control of refining operations is now performed with a lead time of minutes or seconds. Control functions keep process- ing units and blending operations in line with optimization, scheduling, and planning functions. Application of computers to refinery control functions results in better control of finished product specifications. Through automated monitoring of control functions, valuable data are collected to serve as feedback to improve all aspects of refinery operations.

Refinery control functions can be improved by applying expert computer systems which model the decision making process of experienced plant operators. Expert systems serve several functions for plant control including providing all operators with the benefit of knowledge from their most experienced colleagues and smoothing out differences in plant operation practices which may arise due to different philosophies of operators on different shifts. ${ }^{26}$

In addition to actual processing, refiners must purchase and receive crude oil and other raw materials, manage inventories, and produce, market, and ship finished petroleum products. Each of these aspects of refinery operations has been affected by the widespread use of computers.

The advent of global markets for crude oil and petroleum products has made it necessary for refiners to track prices and other developments on a large scale and to make forecasts based on sophisticated computer models. Timely data are required to support decisions concerning processing, inventories, and risk management, through hedging and other means, in order to achieve maximum profitability. The rapid pace and large scale of refining and other petroleum operations have made computers indispensable.

25 Blend Optimization Integrated Into Refinery-Wide Strategy, Oil and Gas Journal (March 19, 1990), p. 40.

26 Expert Systems Trains, Advises Process Operators, Oil and Gas Journal (February 12, 1990), p. 41. 


\section{Refinery Economics}

\section{Introduction}

This chapter examines the financial performance of the domestic refining/marketing sector for companies reporting to EIA's Financial Reporting System (FRS) for the years 1977 through 1988, the last year for which these data are available. ${ }^{27}$ Unless otherwise indicated, all dollar figures have been adjusted for inflation to constant (real) 1982 dollars.

Financial data from the FRS companies were selected and used as a surrogate for the refining industry as a whole because of the ready availability of the data, completeness, reliability, continuity and relative size of FRS companies. During the 1980's, FRS refineries accounted for between 75 and 80 percent of total domestic refining capacity. Although FRS companies are large integrated entities, economic factors such as increases in raw material costs have a similar effect (in this case increased cost) on both FRS and non-FRS companies. However, the impact on the financial health of FRS and non-FRS companies may be significantly different.

The overall financial performance and investment patterns for the refining/marketing sector in the 1980's were heavily influenced by several factors, including the decontrol of domestic crude oil prices in 1981, the severe drop in crude oil prices in 1986 , changes in product demand and crude oil supply, and the introduction of more stringent environmental regulations.

\section{Financial Trends}

\section{Refined Product Margins}

Refined product margins are' a good indicator of overall refinery financial performance. Refined product margin is defined as the difference between refined product costs ${ }^{28}$ and refined product revenues. Refined product margins are shown in Table C13, Appendix C. During the 1980's, refined product margins fluctuated a great deal (Figure 15). This was primarily due to changing market and regulatory conditions in the United States during the decade. The most significant factors affecting margins included the decontrol of the oil industry in early 1981 , the shift in product slates emphasizing gasoline and jet fucls, the plunge in crude oil

\section{Figure 15. Domestic Refined Product Margins for FRS Companies, 1977-1988}

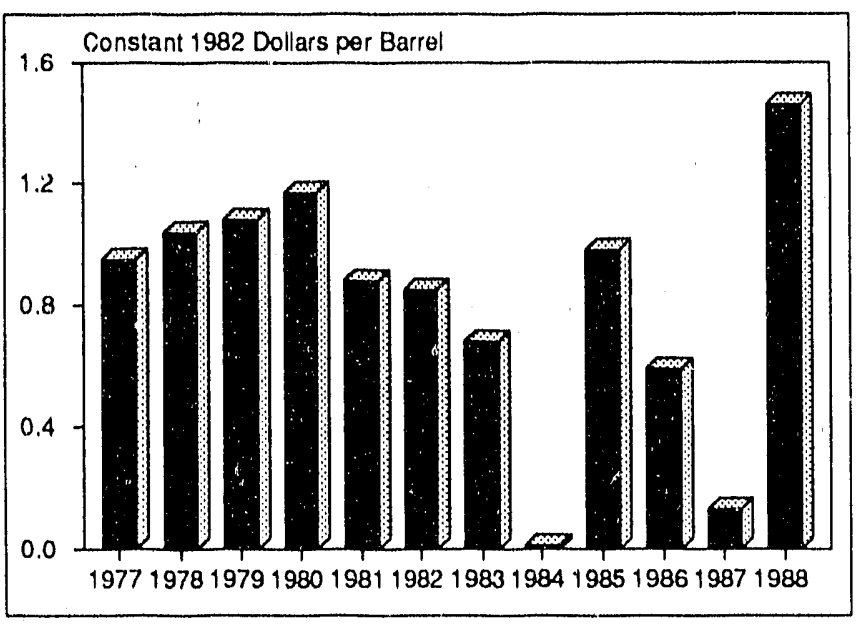

Source: Energy Information Administration, Performance Profiles of Major Energy Producers 1977-1988.

See Table $\mathrm{C}_{13}$ in Appendix $\mathrm{C}$ for corresponding data. The data for 1984 are $\$ 0.01$ per barrel.

\footnotetext{
${ }^{27}$ For a description of the Financial Reporting System (FRS), see Appendix D.

${ }^{28}$ Refined product costs include costs for raw materials processed, refinery energy expense, other refinery expense, product purchases, other product supply expense, and marketing expense.
} 
prices in 1986, the increase in refincry utilization rates, and the wide swings in demand. Each of these factors contributed in some way to the movement of refined product margins over the course of the decade.

From 1977 through 1980, refined product margins for FRS companies were comparatively strong, reflecting the difference in the average sale price for refined products and crude oil costs (Table 6). Margins rose from $\$ 0.95$ to $\$ 1.17$ per barrel (constant 1982 dollars), an increase of 23.2 percent over the 4-year period. The relative strength of margins in the late 1970's and in 1980 were attributed in part to the Federal price and allocation controls in place at that time. Throughout the latter half of the 1970's, many companies purchased or built small refineries to take advantage of the bias toward small refineries in these government programs. A demand mix that favored fucl oils was another factor that made small, simple refineries profitable enterprises. Real reductions in other product supply expenses at refineries also contributed to the resilience in refined product margins during this period.

As a percentage of total product revenues, ${ }^{29}$ however, refined product margins declined steadily between 1978 and 1981, falling from 4.5 pereent of revenues in 1978 to 2.0 percent in 1981 (Table 7). This decrease reflects the sharp jump in the cost of acquiring raw materials during the late 1970's and early 1980's. When adjusted for inflation, the costs per barrel of acquiring raw materials increased 112.1 percent between 1978 and 1981. By 1981, these costs accounted for 73.3 pereent of refined product revenues, compared with 65.2 percent in 1978 . Encrgy expenses as a percentage of product revenues also rose during this period, further reducing the share of product revenues going to product margins.

Price decontrol had an almost immediate effect on the financial performance of domestic refineries. Following decontrol in early 1981, domestic crude oil prices rose to market-clearing levels. The gap between forcign and domestic acquisition costs of over $\$ 11.00$ per barrel in 1980) closed rapidly to under $\$ 3.00$ per barrel in 1981 (constant 1982 dollars), and closed further in succeeding years. The increase in the cost of raw materials to FRS refiners, while significant, was not as dramatic because many of these refiners regularly processed higher-priced foreign crude oils before 1981. The cost of raw materials for FRS refineries peaked in 1981 at $\$ 34.85$ per barrel. Small refineries, however, were no longer able to take advantage of subsidized crude oil pricing arrangements under the Buy-Sell Program, and were thus no longer able to compete.

Table 6. Domestlc Raw Materlal Costs and Average Sale Price of Refined Products for FRS Companies, 1977-1988 (Dollars per Barrel, Except Where Noted)

\begin{tabular}{|c|c|c|c|c|c|c|c|}
\hline \multirow[b]{2}{*}{ Year } & \multicolumn{2}{|c|}{$\begin{array}{c}\text { Raw Material } \\
\text { Costs }\end{array}$} & \multicolumn{2}{|c|}{$\begin{array}{c}\text { Average Sale } \\
\text { Price of Refined } \\
\text { Products } \\
\end{array}$} & \multicolumn{2}{|c|}{$\begin{array}{c}\text { Difference Between Average } \\
\text { Sale Price and Raw } \\
\text { Material Costs }\end{array}$} & \multirow{2}{*}{$\begin{array}{c}\text { Percent } \\
\text { Difference }\end{array}$} \\
\hline & Current & Constant $^{a}$ & Current & Constant $^{\mathrm{a}}$ & Current & Constant ${ }^{\mathrm{a}}$ & \\
\hline 1977 & 11.63 & 17.28 & 15.76 & 23.42 & 4.13 & 6.14 & 35.5 \\
\hline 1978 & 11.86 & 16.43 & 16.65 & 23.06 & 4.79 & 6.63 & 40.4 \\
\hline 1979 & 17.57 & 22.35 & 23.42 & 29.80 & 5.85 & 7.44 & 33.3 \\
\hline 1980 & 27.46 & 32.04 & 34.88 & 40.70 & 7.42 & 8.66 & 27.0 \\
\hline 1981 & 32.76 & 34.85 . & 41.21 & 43.84 & 8.45 & 8.99 & 25.8 \\
\hline 1982 & 29.49 & 29.49 & 38.61 & 38.61 & 9.12 & 9.12 & 30.9 \\
\hline 1983 & 26.84 & 25.83 & 35.36 & 34.03 & 8.52 & 8.20 & 31.7 \\
\hline 1984 & 25.92 & 24.07 & 34.08 & 31.64 & 8.16 & 7.58 & 31.5 \\
\hline 1985 & 24.51 & 22.10 & 33.07 & 29.82 & 8.56 & 7.72 & 34.9 \\
\hline 1986 & 13.32 & 11.69 & 21.02 & 18.45 & 7.70 & 6.76 & 57.8 \\
\hline 1987 & 15.46 & 13.14 & 22.73 & 19.31 & 7.27 & 6.18 & 47.0 \\
\hline 1988 & 12.58 & 10.34 & 21.53 & 17.69 & 8.95 & 7.35 & 71.1 \\
\hline
\end{tabular}

a In 1982 dollars, calculated using implicit GNP price deflators.

b Difference calculated as a percent of raw material costs.

Source: Energy Information Administration, Performance Profiles of Major Energy Producers 1977-1988.

29 Total product revenue represents all revenues generated from the sale of petroleum products. 
Table 7. Refined Product Costs and Margin as a Percentage of Product Revenues for FRS Companles, 1977-1988

(Percent)

\begin{tabular}{c|c|c|c|c|c|c|c}
\hline Year & $\begin{array}{c}\text { Raw Materials } \\
\text { Processed }^{\mathbf{a}}\end{array}$ & $\begin{array}{c}\text { Reflnery } \\
\text { Energy } \\
\text { Expense }\end{array}$ & $\begin{array}{c}\text { Other } \\
\text { Refinery } \\
\text { Expense }\end{array}$ & $\begin{array}{c}\text { Prnduct } \\
\text { Purchases }^{b}\end{array}$ & $\begin{array}{c}\text { Other Product } \\
\text { Supply } \\
\text { Expense }\end{array}$ & $\begin{array}{c}\text { Refined } \\
\text { Marketing. } \\
\text { Expense }\end{array}$ & $\begin{array}{c}\text { Rroduct } \\
\text { Margin }\end{array}$ \\
\hline & & & & & & & \\
1977 & 67.6 & 4.9 & 5.1 & 11.0 & 2.3 & 5.4 & 4.1 \\
1978 & 65.2 & 5.3 & 4.7 & 11.6 & 3.1 & 5.7 & 4.5 \\
1979 & 67.0 & 4.5 & 3.9 & 15.1 & 1.7 & 4.3 & 3.6 \\
1980 & 72.0 & 4.8 & 3.6 & 11.6 & 1.6 & 3.6 & 2.9 \\
1981 & 73.3 & 5.1 & 3.5 & 10.3 & 1.5 & 4.3 & 2.0 \\
1982 & 70.3 & 5.5 & 4.6 & 11.3 & 2.1 & 4.1 & 2.2 \\
1983 & 67.8 & 5.9 & 4.2 & 13.5 & 2.2 & 4.4 & 2.0 \\
1984 & 69.2 & 5.8 & 4.7 & 13.5 & 1.4 & 5.4 & 0.0 \\
1985 & 64.5 & 5.0 & 5.1 & 13.5 & 2.1 & 6.5 & 3.3 \\
1986 & 54.1 & 6.0 & 6.8 & 16.2 & 4.3 & 9.5 & 3.2 \\
1987 & 57.6 & 4.7 & 6.6 & 19.1 & 3.2 & 8.1 & 0.6 \\
1988 & 49.8 & 4.9 & 7.4 & 18.5 & 4.1 & 7.1 & 8.3 \\
\hline
\end{tabular}

\footnotetext{
a Represents reported cost of raw materials processed at refineries, less any profit from raw material trades or exchanges by refinirig/marketing. Includes DOE crude entitlements.

$b$ Includes DOE residual fuel entitlements.

- Excludes cost of marketing tires, batteries, and accessories.

Source: Energy Information Administration, Performance Profilas of Major Energy Producers 1977-1988.
}

Decontrol led to four consecutive years of declining refinery product margins. Relatively ligh, though decreasing, raw material and energy costs, and low overall product demand characterized the period from 1981 to 1984, which was generally one of retrenchment for FRS refining/marketing operations. Because of these and other factors, refined product margins decreased from their high of $\$ 1.17$ per barrel in 1980 to $\$ 0.68$ per barrel in 1983 , and in 1984 plunged to just $\$ 0.01$ per barrel, their lowest level since FRS data were first collected in 1977. As a percentage of refined product revenues, refined product margins, though lower than in the late 1970 's and early 1980 's, were quite steady between 1981 to 1983 , varying from 2.0 to 2.2 percent.

The steep drop in refined product margins in 1984 was the result of unique circumstances. Although the cost per barrel of raw materials decreased for the year, marketing and other refinery expenses increased significantly, climbing an inflation-adjusted 19.8 percent and 6.9 percent, respectively. In addition, average product prices in 1984 declined further than the average cost of refinery inputs. These factors combined to severely squecze refined product margins for FRS refineries during the year.
Refined product margins in 1985 jumped to their highest level since 1980. Margins rose to $\$ 0.98$ per barrel, up from the $\$ 0.01$ per barrel in the previous year (constant 1982 dollars). The introduction of netback pricing was one factor that helped margins recover during the year. However, the most important factor was the improved margin between cost of raw materials and average product prices, due mostly to the recovery in motor gasoline prices and demand in $1985 .^{30}$ The combination of greater demand and robust motor gasoline prices resulted in a large increase in revenues from motor gasoline.

The growing spread between crude oil and average product prices in 1985, however, did not carry over into 1986. Despite the extensive adoption of netback pricing, the gap between crude oil prices and product prices was sufficient to reduce refined product margin to $\$ 0.59$ per barrel. Essentially, netback pricing arrangements assured the purchaser of crude oil of a refining margin and was based on the average cost of a barrel of refined product in a particular market. These pricing arrangements led to sharply lower raw material costs per barrel. With netback pricing arrangements transferring much of the financial risk to producing

\footnotetext{
30 The contrary movement of residual fuel oil and motor gasoline prices between 1984 and 1985 was, in part, a consequence of the nearly year-long coal strike in the United Kingdom. The strike stimulated increased demand for heavy fuel oils to replace coal in dual-fired electric genertikig plants. Expanding residual fuel oil production, however, led to incremental increases in the production of other products, such as motor prices returned to market-clearing levels.
} 
countries, refiners could afford to introduce more competitive product prices. The result was a drop in product prices anú slimmer margins. The sharp drop in crude oil prices during 1.986 also led to adverse financial effects due to increased costs of inventory management and losses from trading activities. However, as a percentage of refined product revenues, product margins were 3.2 percent in 1986, about the same as in 1985.

The decrease in refined product margins to $\$ 0.13$ per barrel in 1987 was due primarily to the turnaround of crude oil prices in the first half of the year, as Saudi Arabia and other OPEC nations trimmed crude oil production and returned to a fixed-rate pricing system. Crude oil prices recovered to over $\$ 19.00$ per barrel by July 1987 . However, increases in product prices lagged, and this drove margins lower in the first half of 1987. In the fall and winter of 1987, crude oil prices eroded and product prices recovered, helping margins to recover, but not enough to offset the earlier decreases. Nonetheless, the financial momentum established late in the year continued into 1988.

In 1988 , refined product margins rose to a record high of $\$ 1.46$ per barrel (constant 1982 dollars) and accounted for 8.3 percent of total refined product revenues. Much of the increase was the result of the decline in raw matcrial costs, which fell at a faster rate than product prices. Motor gasoline prices were particularly solid in 1988 and were the largest component of the increasing spread between the cost of raw materials and average product prices. Improved efficiency from higher utilization rates also contributed to the sharp rise in product margins during the year.

\section{Relative Contributions of Production, Refining/Marketing, and Rate Regulated Pipelines to the Financial Performance of FRS Companies}

FRS companies operate as oil and gas producers, refiners/marketers, and pipeline operators. The overall financial results of these companies reflect the balance struck among these different profit centers. Throughout the first half of the 1980's, the production sector generated most of the domestic income for FRS companies. However, as a result of the sharp drop in crude oil prices in late 1985 and 1986, income from the refining/marketing sector increased as a share of overall domestic petroleum industry income.

Before 1986, income from the production sector contributed a larger share than the contributions from the refining/marketing or rate regulated pipelines sectors. This was primarily because of the high cost of crude oil. Between 1977 and 1985, net income from the production sector accounted for between 70 and 85 percent of total domestic income (Figure 16). The contribution of refining/marketing income to total domestic income during this period remained below 18 percent, and reached a low of under 1 percent in 1984. Income from rate regulated pipelines was less variable, fluctuating from 8 to 16 percent of total domestic FRS income.

The years 1986 to 1988 were especially lean ones for the domestic petroleum industry in general, but particularly for the production sector. The introduction of crude oil netback pricing arrangements in 1985 and the sharp decrease in crude oil prices in early 1986 caused overall net income for FRS companies to fall abruptly. In 1986, income in the production sector of FRS companies registered a particularly steep decline, decreasing from $\$ 10.9$ billion in 1985 to just $\$ 0.8$ billion (in constant 1982 dollars), a drop of over 90 percent. Consequently, production sector income fell to just 18 percent of total domestic FRS income in 1986.

FRS company income from the refining/marketing sector also decreased in 1986, but at a much lower rate than production income. Netback pricing was instrumental in maintaining adequate refining margins throughout the year. This type of pricing arrangement is particularly advantageous during periods of price instability because netback pricing transfers much of the financial risk associated with price swings from refiners to producers. However, lower crude oil prices lead to increased losses from trading activities.

As a result, real refining/marketing income in 1986 was 30 percent below its level in 1985. Still, refining/marketing income in 1986 exceeded domestic crude production income for the first time since FRS data were initially collected in 1977, and its contribution to total net income rose to 32 percent. Pipeline sector income, which increased 9 percent in 1986, also increased as a share of total net income to 50 percent.

An increase in crude oil prices of over $\$ 3.00 \mathrm{per}$ barrel coupled with reduced operating costs led to a modest turnaround in production sector income in 1987. Although revenues were still well below pre -1986 levels, crude production income improved to 56 per :ent of total domestic income. In contrast, higher crude oil prices and the end of widespread trading in netback-priced crude oil adversely affected refining/marketing sector income of FRS companies, causing it to fall to 13 percent of total income in 1987.

In 1988 , crude oil prices again decreased, sliding over $\$ 3.00$ per barrel during the year. Moreover, throughout most of 1988 crude oil prices fell at a faster rate than did refined product prices, particularly gasoline, increasing the differential between crude oil and product prices. Income for 


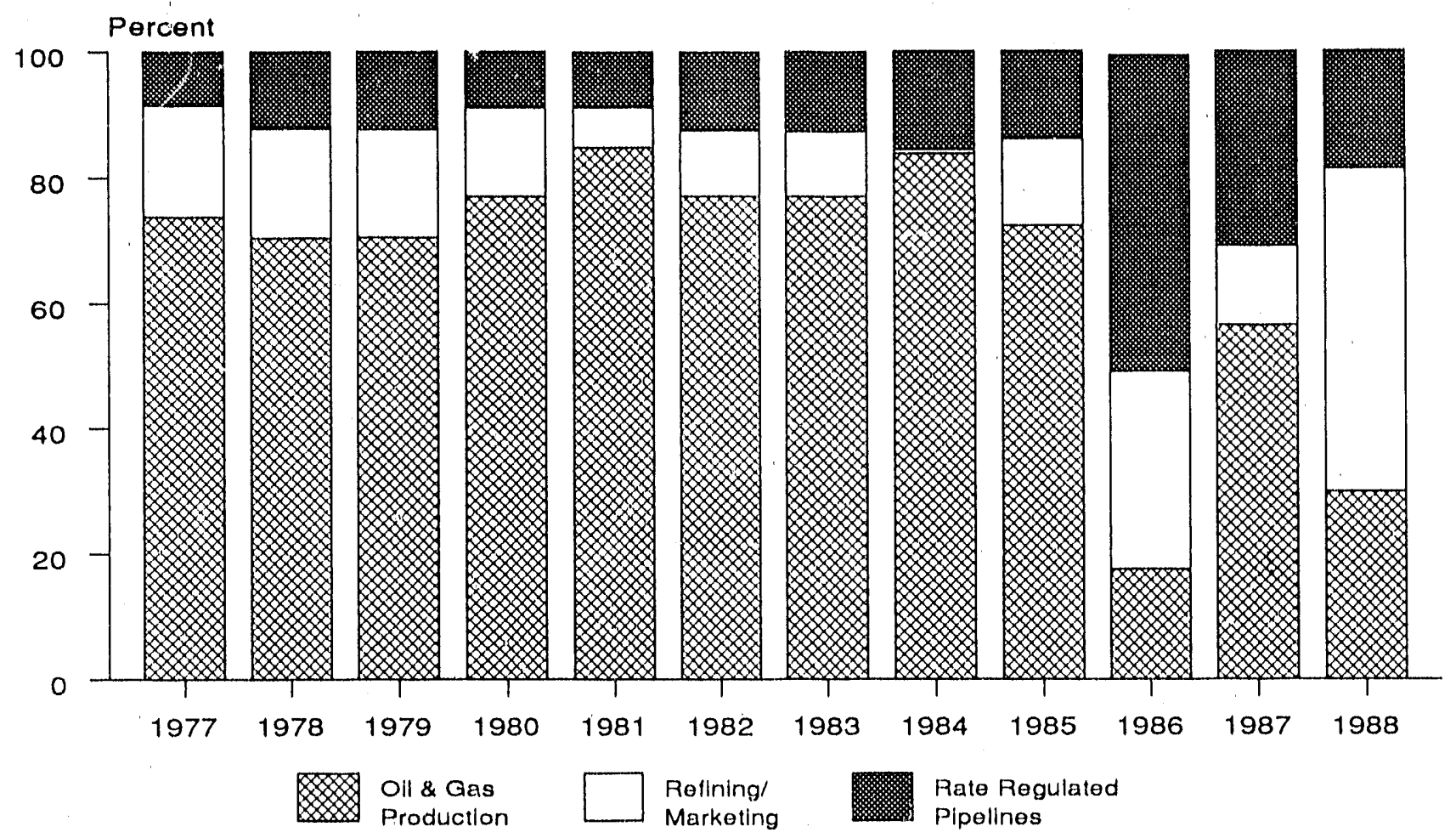

Source: Energy Information Administration, Performance Profiles of Major Energy Producers 1977-1988.

See Table C14 in Appendix C for corresponding data.

the FRS refining/marketing sector reached an all-time high of $\$ 4.5$ billion (constant 1982 dollars) and accounted for 50 percent of total domestic FRS income, compared with a 31percent share of net income from the production sector.

These shifts in the relative contributions to income from the production, refining/marketing, and pipeline sectors of FRS companies in the 1980's demonstrated the economic benefits of vertical integration during a decade characterized by increased regulatory activity and price instability. Large, integrated petroleum companies with production, refining/marketing, and transportation interests were better suited to cope with rapidly changing market conditions. Losses suffered in one sector of the company were offset by gains in another. The shift in the relative contributions of irodiction and refining/marketing income for FRS companies from 1987 to 1988 is an example of this. Independent producers, refiners, marketers, and transporters, who occupy specialized niches in the domestic petroleum industry, were not as flexibile. This shortcoming was magnified by decontrol and price volatility. Independents thus operated at greater risk from the effects of market instability.

\section{Product Purchases for FRS Companies}

Refiners also controlled their financial risk through a strategy of inventory management. Inventory management practices cut refined product inventories to the minimum required for efficient operations while making sure that adequate crude oil stocks were available to meet incremental increases in product demand. Bcfore 1986, high interest rates and deteriorating prices provided the impetus for reducing produci stock inventories. ${ }^{31}$ In addition, refiner closings reduced available storage at refineries. Since 1986, price instability has led refiners to focus more on inventory management as a way to reduce risks and costs.

${ }^{31}$ Obel, Michacl, "Refiners Meet U.S. Demand With Less Product In Inventory," Oil and (Gas Journal (February 17, 1986), pp. 19-22. 
Refiners adjusted to these circumstances by regulating product stock levels more closely and increasing product purchases. Lowering product stock levels to the minimum necessary to conduct normal operations, while at the same time maintaining adequate inventory to handle demand spikes, limited the financial exposure of refiners to rapid decreases in product prices.

Product purchases by refiners became an important element of overall inventory management practices throughout the decade, but were used even more following the plunge in crude oil prices in 1986. For example, between 1977 and 1985, annual product purchases for FRS refineries averaged 648 million barrels, with annual totals ranging from $50($ ) to 800 million barrels. From 1986 to 1988, product purchases were substantially higher, averaging 998 million barrels with purchases exceeding 900 million barrels all 3 years. Increased purchases were experienced in motor gasoline, distillate fuel oil, and other products.

The amount spent on product purchases in the refining/marketing sector also became a larger component of refined product revenues for FRS companies after 1985 (Table 7). Annual product purchases, which ranged from 10 to 13.5 percent of product revenues for all but one year from 1977 to $1985,{ }^{32}$ averaged 17.9 percent of revenues after 1985. These data suggest that the price instability experienced since 1985 has led FRS refiners to expand the role of product purchases in inventory management.

\section{Refinery Energy Costs for FRS Companies}

Refiners are large consumers of energy, and expenses for fucl and electricity are a major element of total refined product costs. A large portion of the fucl consumed during refining operations is derived as a by-product of processing crude oil. The acquisition cost of crude oil is therefore the foremost component of energy cost at a refinery. The price of crude oil also has a large impact on natural gas, electricity, and other energy sources consumed at refineries.

The major factor in increased energy costs at refineries in the late 1970's and early 1980's (Figure 17) was the jump in crude oil prices from late 1977 to 1981 . From $\$ 6.1$ billion in 1977, total refinery energy expenses for FRS companies peaked in 1981, topping $\$ 9.9$ billion (constant 1982 dol- lars). The reductions in energy expenses at FRS refineries after 1981 accompanied the decrease in crude oil prices. This downward trend in total energy expenses persisted even though FRS facilities consumed increasing quantitics of energy. The increase in consumption at FRS refinerics was mainly the result of reduced distillation capacity at non-FRS companies brought about by refinery closings and renewed growth in refined product demand, particularly after 1985. With fewer refincries in operation, existing FRS facilities were required to process larger quantities of refinery inputs which use greater quantities of energy. The growth in downstream operations during the 1980's, largely the result of Federal environmental guidelines and shifting product demand patterns, was another factor which expanded energy use at FRS refineries.

\section{Figure 17. Domestlc Refinery Energy Expense for FRS Companies, 1977-1988}

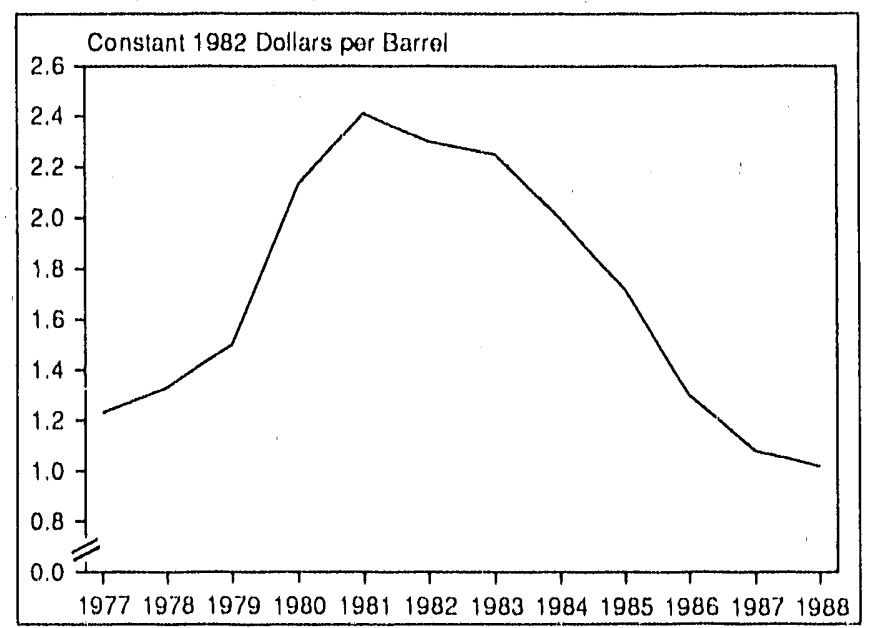

Sourco: Energy Information Administration, Performance Profiles of Major Energy Producers 1977-1988.

See Table C15 in Appendix C for corresponding data.

Much of the increased cost of energy that went into producing a barrel of finished product between 1977 and 1981 was recouped through the higher selling price charged for finished products. As energy expenses at refineries fell after 1981, the decrease in energy costs was reflected in lower product prices. As a result, energy expenses as a percentage of refined product revenues remained in a comparatively narrow range during the decade, even during periods of severe price instability. From 1977 to 1988, for example, energy expenses at refinerics were consistently between 4.5 and 6.0 percent (Table 7).

32 In 1979, product purchases were 15.1 percent of refined product revenues. 
When considered as a component of refinery production, however, refinery energy expenses fell in tandem with the overall decrease in energy prices. Energy costs per barrel of refinery output for FRS refineries, which rose steeply from 1977 to 1981 , fell steadily after 1981. Using constint 1982 dollars, the real cost of energy per barrel of output declined from $\$ 2.41$ in 1981 to $\$ 1.02$ in 1988 , a drop of 58.0 percent.

Another factor affecting energy usage and cost was the increased use of conversion and treatment units to meet stricter environmental standards on motor fuels and the growing demand for higher octane motor gasolines. Because of these demands, refiners were compelled to operate downstream units at a higher rate of utilization and often under more severe operating conditions of temperature and pressure. These types of intensive downstream processing operations consume large quantities of energy and will take up an even larger portion of total energy expenses at refincries. As more emphasis is placed on downstream processing in the coming years, the proportion of total refinery energy expenses incurred from downstream processing may grow, even as total energy expense per-barrel of output decreases. Downstream energy costs can be controlled somewhat by upgrading existing equipment and installing new equipment that requires less energy to operate. New catalysts also have been developed and employed to improve energy efficiency.

\section{Refinery Investments and Upgrades}

A large portion of the refining investment by FRS companies during the 1980's went to upgrade facilities and expand downstream capacity. Factors which drove the rise in investment throughout the decade include shifting product demand away from heavy fuel oils to light products, the increased availability of high-sulfur crude oils, the price spread between light and heavy crude oils, and restrictions on lead content. The anticipation of additional environmental regulations governing motor gasoline vapor pressure and reducing the sulfur content of diesel fuel were other factors that induced investments in downstream capacity and ancillary equipment, such as storage tanks, sulfur plants for converting hydrogen sulfide to sulfur and water, sulfur strippers for water treatment, and tail-gas units. Improved refining profitability in the latter half of the decade was another factor which led to rising downstream investments.
These types of modernization programs have permitted refiners to produce higher quality products, improve yields, reduce additive costs, and save energy.

Refining investments for FRS companies rose between 1980 and 1982 despite substantial capacity reductions and declines in total product sales. Measured in constant 1982 dollars, more than $\$ 12$ billion was committed in this 3-year period (Figure 18).

This growth reflected the continuing upward trend in refinery investment begun in the late 1970's. Between 1977, the first year for which FRS data are available, and 1982, additions to refining investment in place ${ }^{33}$ grew at an average rate of 27.5 percent per year. Expenditures to increase downstream capacity constituted the bulk of the investments. Most of t.iese investments, were directed towards expanding vacuum distillation, hydrotrcating, coking, and octane-enhancing capabilities.

Upgrades such as these enabled refiners to run lower grade crude oils which permitted them to take advantage of the relatively large price differential that existed between light and heavy crude oils. This flexibility grew in importance after oil decontrol in 1981, when refined product margins were pinched. Upgrades also were required to increase refinery yields of light products like kerosene-type jet fuel

\section{Figure 18. Additions to Investment for Domestic Petroleum Refining for FRS Companies, 1977-1988}

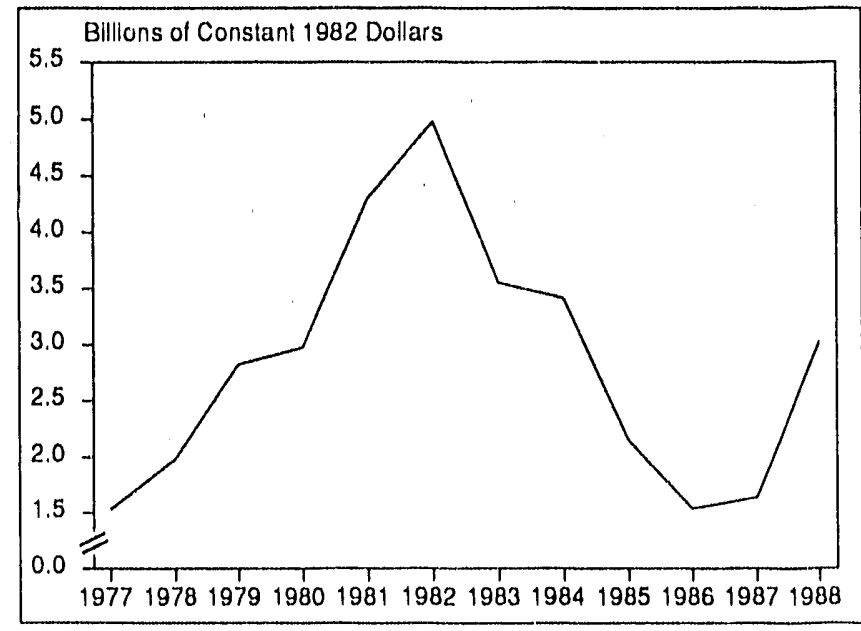

Source: Energy Information Administration, Performance Profiles of Major Energy Producers 1977-1988.

See Table C 16 in Appendix C for corresponding data.

\footnotetext{
33 Additions to net investment in place is the sum of additions to property, plant, and equipment plus additions to investment in unconsolidated affiliates.
} 
that were in growing demand, and to reduce yields of the heavy fucl oils that were losing market share.

In late 1982 and 1983, a number of major refinery upgrading projects for FRS companies were completed. Few upgrading projects were initiated in 1983, and most of these tended to be comparatively small. As a result, additions to investment in refining dropped 28.5 percent. Investment continued to fall through 1986 and only inched marginally higher in 1987. Over this period, annual additions to refining investment in place declined by an average of 18.4 percent. From a peak of nearly $\$ 5.0$ billion in 1982, addlitions to investment plunged to a low $\$ 1.5$ billion in 1986 (constant 1982 dollars).

The narrowing spread between light and heavy crude oils was one factor that contributed to the overall drop in outlays for refinery upgrades. In 1980, the spread between a typical light crude oil and a heavy crude oil was about $\$ 11.00$ per barrel, but by 1985 , low-quality crude oils commanded about the same price as medium grade crude oils. This development contributed to the uncertainty regarding the potential profitability of investments in refinery upgrades. Refiners also shifted their investments after 1982 and began to concentrate more on gasoline production and octanc boosting units, which were more economical to operate than desulfurization equipment. Contributing to this move in downstream investment towards gasoline production units was the growing demand for unleaded gasoline. This was especially true of premium unleaded grades. While production of premium unleaded gasoline requires greater use of oetane-cnhancing capacity, premium gasolines tend to have higher profit margins than other grades of gasolines.

In 1988 , investment in refining rebounded sharply, jumping by 85.2 percent to $\$ 3.0$ billion in constant dollars. Improved profits in the refining/marketing sector in the latter half of the 1980's was one reason investment increased in the late 1980's. Most of the increase, however, was fueled by a series of environmental regulations. Although most refiners were able to comply with the first phase of EPA's Reid Vapor Pressure (RVP) restrictions using existing equipment, upgrades were necessary at some plants. Plans for

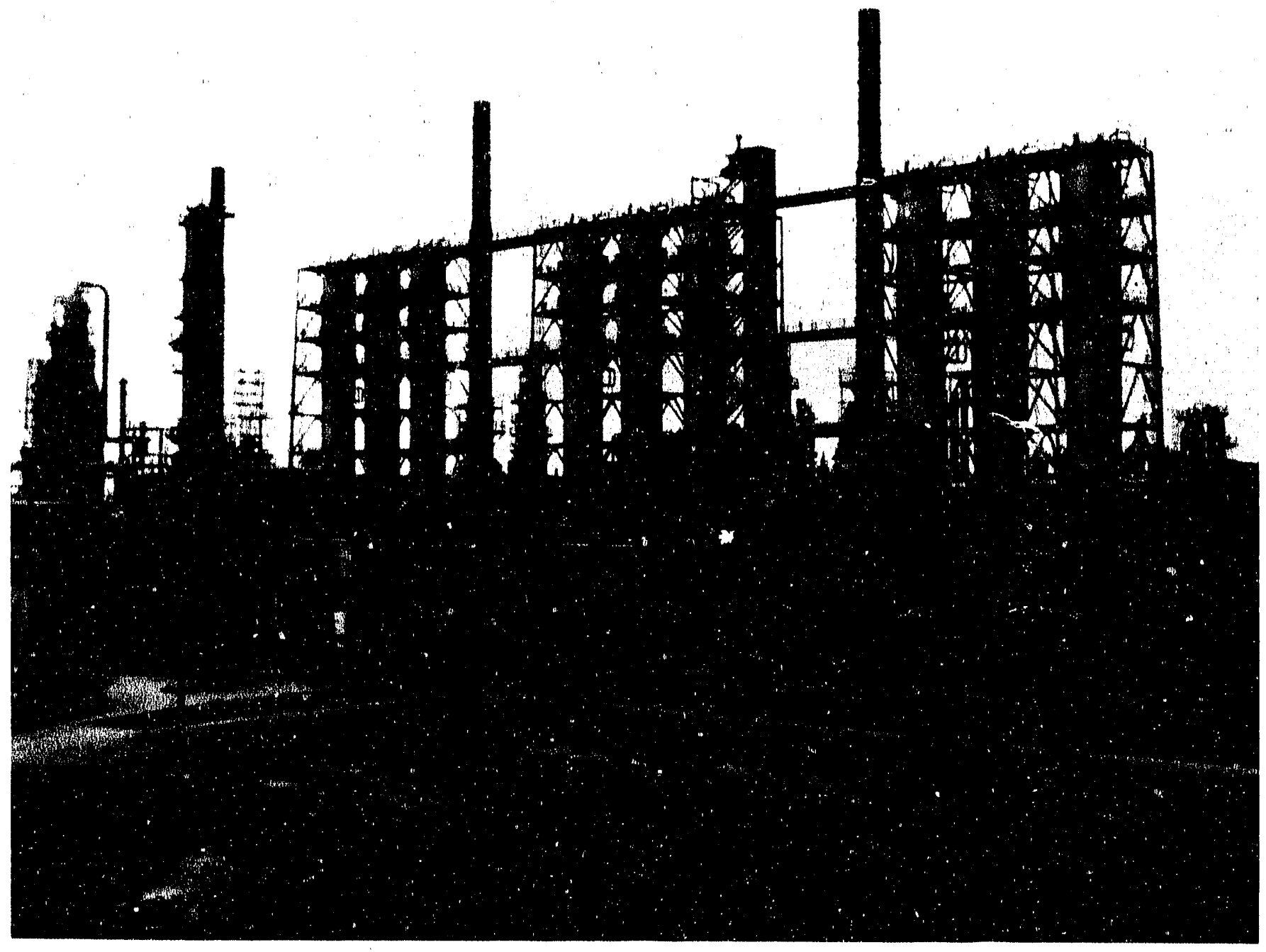

Investments in refinery upgrades are expected to remain at a relatively high level into the 1990's. 
new gasoline producing capacity were developed and implemented in response to the more stringent volatility requirements anticipated for the summer of 1992. Hydrotreating equipment also was added at some refineries in expectation of an impending cut in the allowable sulfur content of diesel fuel from 0.265 percent to 0.05 percent by weight, expected to take effect in 1993.

Investments in refinery upgrades are expected to remain at a relatively high level into the 1990 's. Refiners are now poised to spend billions of dollars to upgrade their facilities to meet the environmental restrictions contained in the new amended Clean Air Act and other legislation pending in Congress.

\section{Increased Role of Futures Market}

In the 1980's, more and more refiners and oil companies in general took advantage of oil futures markets to minimize their exposure to sudden changes in price. Trading in oil futures, which began slowly with the introduction of a No. 2 fucl oil contract on the New York Mercantile Exchange (NYMEX) in 1978, grew rapidly in the 1980's. A futures contract is a contract between a seller and a buyer to make or take delivery of an accepted commodity on a designated date in the future. The contract also defines a standard quantity and quality of the product and the point of delivery. The value of a futures contract is determined by trading on the exchange floors and varies with market perceptions about supply, demand, weather, regulatory action, political upheaval, and other factors.

Following the somewhat lackluster reception of the initial No. 2 fuel oil contract in 1978, interest in oil futures began to rise sharply. In 1981, a gasoline futures contract was introduced on NYMEX, followed by a contract for West Texas Intermediate crude oil in 1983. More recently, in late 1989 a contract for residual fucl oil futures " also tried for a short time a few years earlier "was introduced. Options for crude oil and heating oil also were introduced on the NYMEX in 1986 and 1987, respectively. Options differ from futures in that the owner is under no obligation to make or take delivery of the product in the futures contract.
In the 1980's, comparable futures markets also began to surface and grow in the international markets. Early in the decade, petroleum futures for gas oil and Brent Blend crude sil began to be traded on a large scale on the International Tholeum Exchange of London. In February 1989, the Singapore Monetary Exchange introduced a high sulphur fuel oil contract. In November 1989, ROEFEX, in Rotterdam, Netherlands, began trading in oil futures as well.

For a variety of reasons, oil companies became increasingly active players in the futures markets, particularly in the latter half of the 1980's. As a result of the price volatility after 1985, many buyers and sellers were reluctant to enter into long-term supply arrangements at a fixed price. In the midst of these price and supply uncertainties, the futures markets provided refiners with a way of reducing risks and an opportunity to increase profits. At the end of the decade, more than two-thirds of the contracts traded in the oil futures market were held by commercial oil firms. ${ }^{34}$

Hedging is practiced by some refiners as part of a larger corporate strategy and by others on a transaction-by-transaction basis to reduce the exposed risk for each transaction. Risk management is accomplished chiefly through the process of hedging, or the taking of contrary positions in the oil futures and spot markets. Buying hedges protects against an unexpected increase in spot market prices whereas selling hedges protects against an unexpected decrease in spot market prices. In this way, refiners reduce the potential for making large profits but also avoid potentially large losses in case spot prices move contrary to what is expected.

Though speculating in the futures markets is common, most oil companies in the 1980's used the futures markets for hedging. Recent data compiled by the National Petroleum Council show that for firms or individuals holding 25 or more contracts at the end of March 1988, 92.0 percent of the contracts held for unleaded gasoline, 85.0 percent of the contracts held for No. 2 fuel oil, and 85.6 percent of the contracts held for crude oil were used for hedging, not speculation. ${ }^{35}$ Debate persists on whether the continuing growth of the futures markets introduces more stability to oil markets or adds greater uncertainty to them. As long as prices remain unstable, however, refiners will continue to use the futures and spot markets to help manage exposed risk.

\footnotetext{
34 Thompson, R. Patrick, "NYMEX Futures, Options Volumes Continue To Grow," Oil and Gas Journal (Janıary 22, 1990), pp. 42-43.

35 National Petroleum Council, Petrole um Inventories and Storage (Vol. IV), April 1989, pp. F-1 to F-8. This study also suggests that while most companies are active in the futures markets to reduce risk, petroleum futures do not significantly affect stocks levels in the primary distribution systems.
} 


\section{Refinery Ownership}

\section{Introduction}

Ownership of U.S. refineries changed appreciably in the 1980 's, as mergers, takeovers, and foreign investments altered the structure of the refining industry (Table 8).

Historically, the U.S. petroleum industry, (including refineries) consisted of a mix of large integrated companies often known as major companies and smaller, independent companies often known as non-majors. Major companies generally own and operate establishments in all facets of the petroleum industry from exploration and crude oil produc-

Table 8. Sallent U.S. Refinery Ownership Statistics, 1980 and 1990

\begin{tabular}{|c|c|c|c|}
\hline Item & 1980 & 1990 & $\begin{array}{l}\text { Percent } \\
\text { Change }\end{array}$ \\
\hline Number of Companies ....... & 188 & 108 & -42.6 \\
\hline Number of Refineries ......... & 319 & 205 & -35.7 \\
\hline $\begin{array}{l}\text { Crude Distillation } \\
\text { Capacity }\end{array}$ & & & \\
\hline $\begin{array}{l}\text { Total U.S. } \\
\text { (thousand barrels per day) }\end{array}$ & 17,988 & 15,572 & -13.4 \\
\hline $\begin{array}{l}\text { Foreign Affiliated }{ }^{b} \\
\text { (percent of U.S.) }\end{array}$ & 11.1 & $27.1^{c}$ & - \\
\hline
\end{tabular}

a Crude distillatior capacity as of January 1 , of the year indicated.

b Based on crude distillation capacity as of December 31, of the preceding year indicated.

- Percentage as of 1988.

Sources: Energy Information Administration, Profiles of Foreign Investment in U.S. Energy 1983, p. 17 and 1988, p.19. Energy Data Report, "Petroleum Refineries in the United States and U.S Territories," and Petroleum Supply Annual 1989. tion to refining and marketing. Non-major companies, although greater in number than the majors, own a smaller share of the industry. Non-major companies generally specialize in one particular activity of the industry such as exploration and production or refining and marketing.

\section{Changes in Ownership}

The consolidation of the petroleum industry in the 1980's, via mergers, sales, and acquisitions, significantly reduced the number of companies operating refineries during the decade. The number of operable refineries and associated crude distillation capacity also showed declines during this same period.

From January 1, 1980, through January 1, 1990, the U.S. refinery industry lost 80 companies, 114 refineries, and 2.4 million barrels per day of crude distillation capacity (Figures 19, 20, and 21).

The consolidation of the U.S. refining industry occurred over a relatively short period of time. The 3-year period from 1982 to 1985 accounted for 76.3 percent of the total decline in the number of companies in the 1980's, 68.4 percent of the overall decline in the number of refineries, and 92.3 percent of the loss in crude distillation capacity during this same period.

For the majors, the number of companies fell from 23 in 1980 , to 18 by 1990 , a drop of 5 companies. On the other hand, the number of non-major companies fell by 45.5 percent during this same period, from 165 companies in 1980, to 90 companies by 1990 .

Correspondingly, crude distillation capacity of those refineries closing in the 1980's totaled 2.4 million barrels per day, a decline of 13.4 percent. However, partially offset- 
Figure 19. Number of U.S. Refining Companles, by Major and Non-Major Company Ownershlp, 1980-1990

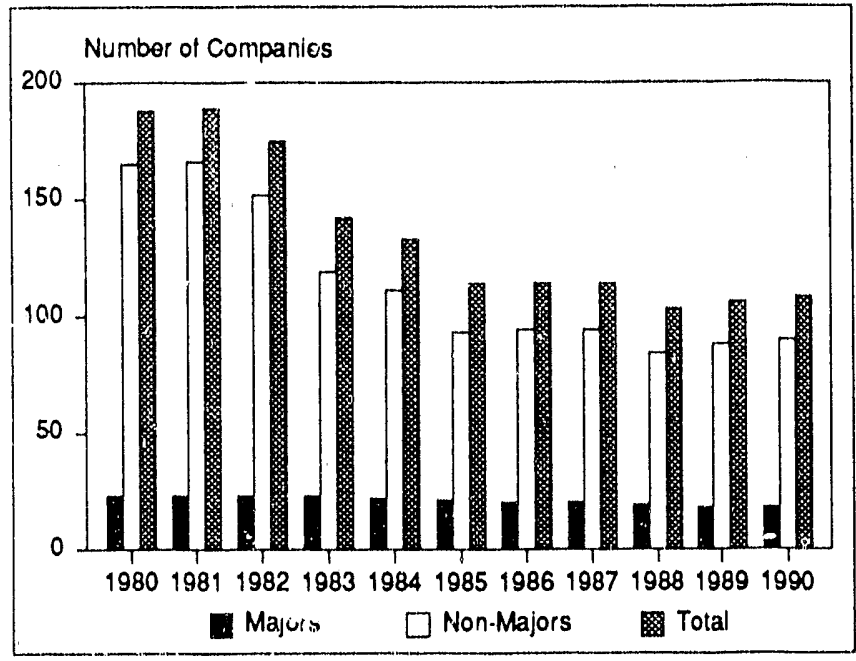

Note: Number of companies as of January 1 in each year.

Source: Energy Information Administration, Energy Data Report "Petroleum Refineries in the United States and U.S. Territories," Petroleum Supply Annual 1981-1989.

See Table C17 in Appendix C for corresponding data.

Figure 20. Crude OlI Distillation Capacity, by Major and Non-Major Company Ownership, 1980-1990

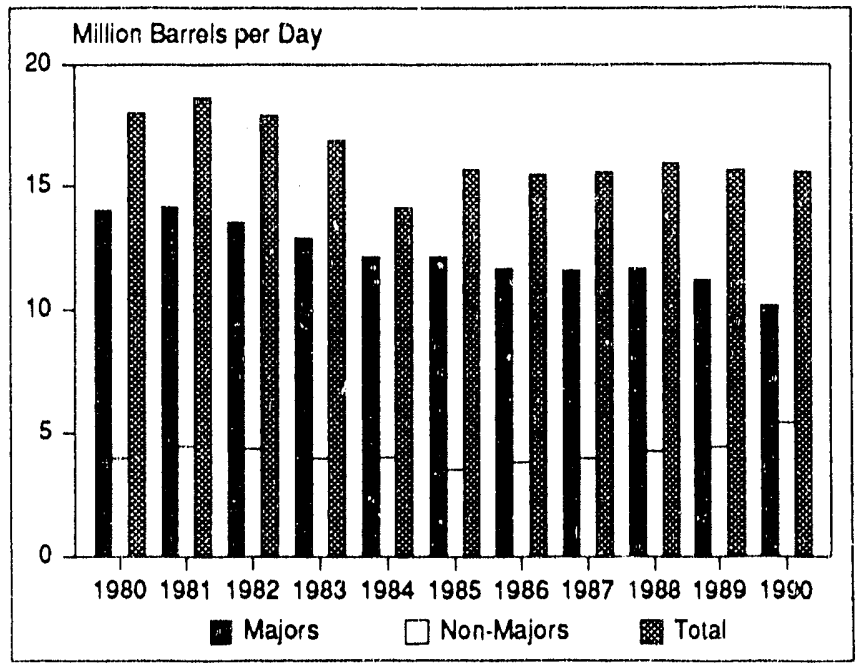

Note: Crude distillation as of January 1 in each year.

Source: Energy Information Administration, Energy Data Report, "Petroleum Refineries in the United States and U.S. Territories," Petroleum Supply Annual 1981-1989.

See Table C18 in Appendix C for corresponding data.
Figure 21. Number of U.S. Refinerles, by Major and Non-Major Company Ownership, 1980-1990

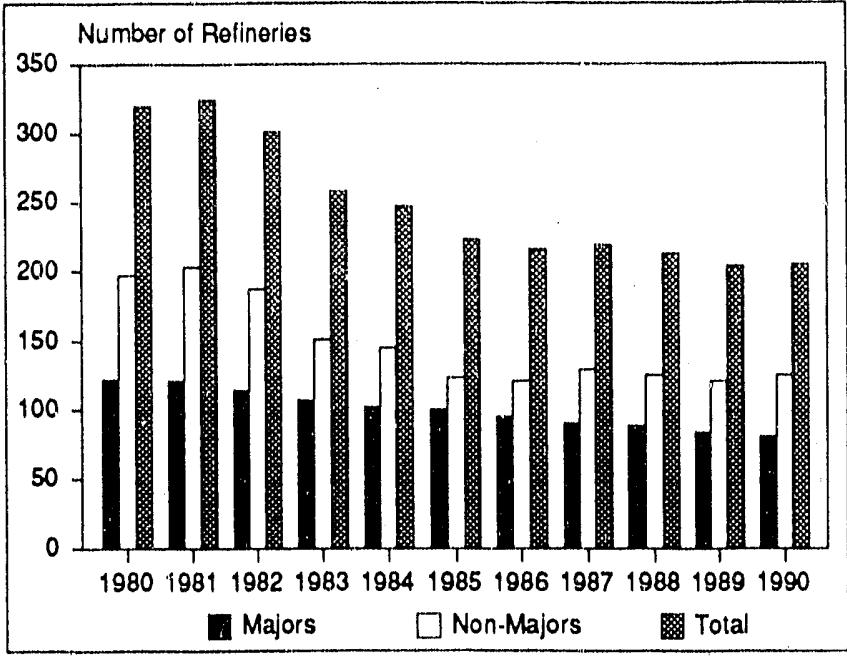

Note: Number of refineries as of January 1 in each year. Sources: Energy Information Administration, Energy Data Report, "Petroleum Refineries in the United States and U.S. Territories, "Petroleum Supply Annual 1981-1989.

See Table C19 in Appendix C for corresponding data.

ting some of this decline was the 1.4-million-barrel-per-day gain in crude distillation capacity by non-major companies. The gain in crude distillation capacity by non-major companies occurred despitc reductions in both the number of non-major companics and number of refineries. The major companies lost 3.9 million barrels per day of crude distillation capacity from 1980 to 1990.

\section{Mergers and Sales}

\section{Company Mergers}

Petroleum company inergers and refinery sales activity remained strong throughout the 1980's, particularly in the first half, as the petroleum industry adjusted to declining crude oil prices and changing world oil markets. These adjustments included several highly publicized takeover attempts by both friendly and hostile means, a number of 
record-setting mergers, and a major restructuring of the petroleum industry, via refinery closures and sales.

Although many factors are responsible for the rash of merger activity in the 1980 's, the most prominent factor was the make or buy decision regarding crude oil reserve additions. Some petroleum companies depended on reserve purchases to augment their U.S. crude oil position (buy group), and some relied on their own exploration and development efforts to replace oil production (make group).$^{36}$ The majority of petroleum industry merger activity in the 1980's was mostly within the buy group of companies, as declining crude oil prices forced some companies to reduce their expenditures for exploration and development.

The 1984 merger of Getty Oil Company with Texacu Inc. exemplify's this fact. Texaco decided to acquire Getty Oil Company to assure itself of access to secure reserves of U.S. crude oil, and to enhance its prospects of adding future reserves by increasing the exploratory acreage in which it holds interests. ${ }^{37}$ At the same time, Texaco divested many of Getty's assets that did not meet the company's business strategies, including Getty's marketing operations in the Northeastern United States. However, Getty's three refineries, with combined crude distillation capacity of 269,000 barrels per day, were retained by Texaco (Table 9).

Similar to the Texaco/Getty merger, the merger of Gulf Oil Corporation with Chevron Corporation in 1985, was based on the acquisition of crude oil reserves. Because crude oil in the United States has become more difficult and costly to produce, Chevron's acquisition of Gulf nearly doubled the company's worldwide reserves. ${ }^{38}$ This merger also provided Chevron with four refineries having a combined crude distillation capacity of 663,000 barrels per day.

However, not all mergers in the 1980's were between petroleum companies or for the sole purpose of acquiring crude oil reserves. USX Corporation (formally U.S. Steel Corporation) acquired Marathon Oil Company in 1982 to provide the steel company an energy hedge for the energydependent company, along with raw material support for their chemicals business. ${ }^{39}$ Moreover, chemical industry giant, Du Ponts' acquisition of Conoco Inc. in 1981, represented yet another example of a nonrelated industry merger. Although the acquisition of Conoco provided Du Pont with ownership of major crude oil, natural gas, and coal reserves, it also provided the company with diversification into energy and chemical feedsiocks. ${ }^{40}$

Table 9. Selected Petroleum Industry Mergers, 1980-1990

\begin{tabular}{|c|c|c|c|c|}
\hline Affected Company & Acquiring Company & $\begin{array}{l}\text { Number of Refineries } \\
\text { of Affected Company }\end{array}$ & $\begin{array}{l}\text { Combined Crude } \\
\text { Distillation Capacity } \\
\text { Of Affected Refineries } \\
\text { (thousand barrels } \\
\text { per day) }\end{array}$ & $\begin{array}{l}\text { Year of } \\
\text { Merger }\end{array}$ \\
\hline Conoco Inc. & E.l. du Pont & 8 & 475 & 1981 \\
\hline Marathon Oil Co. & U.S. Ste日l & 4 & 588 & 1982 \\
\hline Cities Service Co. & Occidental Petroleum & 1 & 320 & 1983 \\
\hline Getty Oil Co. & Texaco Inc. & 3 & 269 & 1984 \\
\hline Superior Oil Co. & Mobil Oil Corp. & 0 & 0 & 1984 \\
\hline Gulf Oil Corp. & Chevron Corp. & 4 & 663 & 1985 \\
\hline
\end{tabular}

Source: Energy Information Administration, Petroleum Supply Annual 1981-1989, Refinery Statistics section.

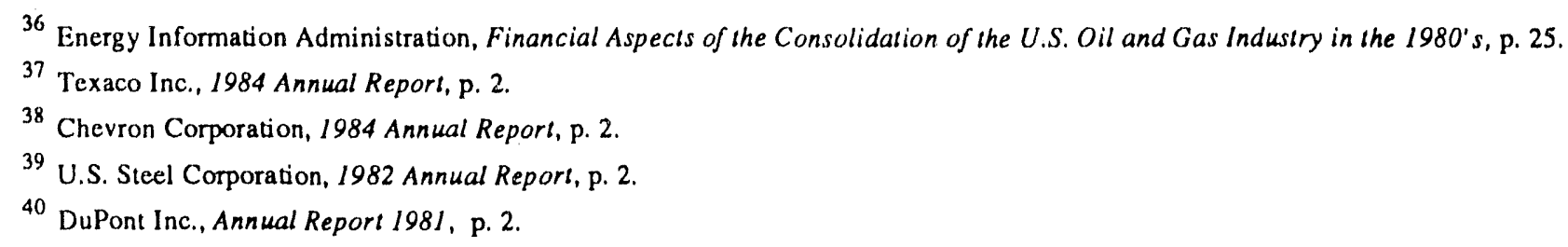




\section{Refinery Sales}

Reflecting the high level of excess refining capacity at the beginning of the 1980's, coupled with the start of the decline in crude oil prices in 1981, the petroleum industry began a period of restructuring that kept refinery sales strong for most of the decade. Between 1980 and 1990, the refinery industry sold 128 refineries with a combined crude distillaticn capacity of 7.5 million barrels per day (Table 10 and Table B4).

The number of refineries sold as a percent of all operating refineries ranged from a decade low of less than 2.0 percent in 1980 , to a decade high of nearly 10.0 percent in 1988. Similarly, crude distillation capacity associated with refineries sold ranged from a decade low of 1.1 percent of total crude distillation capacity in 1980 , to a high of over 10.0 percent in 1988.

However, for some years, the high level of activity was the result of a single merger or transaction, as was the case in 1981,1982 , and 1985. For these years, a single merger or transaction accounted for over half of the affected crude distillation capacity.

\section{Incursion of Foreign Ownership}

The presence of foreign-affiliated companies and their involvement in U.S. refining dates back many years. Shell Oil Company and BP America for years accounted for practically all toreign investment in U.S. refining operations. However, during the 1980's foreign investment in U.S. refining grew dramatically. This growth was the result of the improvement in U.S. refining profitability in the latter part of the 1980's, and was also the result of a new type of foreign-based entity, national oil companies of oil exporting countries.

In order to gain a secure market outlet for their oil, national oil companies of oil exporting countries, including some members of the Organization of Petroleum Exporting Countries (OPEC), sought joint ventures and acquisitions in the U.S. refining industry. Generally falling crude oil prices in the 1980's, coupled with improved refiner profitability were factors contributing to this move.

In 1980, foreign-affiliates' share of U.S. crude distillation capacity equalled 11.1 percent, or 2.1 million barrels per day. By 1988, foreign-affiliates' share increased to 27.1

Table 10. Total Refinery Sales, 1980-1990

\begin{tabular}{c|c|c|c|c}
\hline \multirow{2}{*}{ Year } & \multicolumn{2}{|c|}{ Refinery Sales } & \multicolumn{2}{c}{ Crude Distillation Capacity } \\
\cline { 2 - 5 } & $\begin{array}{c}\text { Number of } \\
\text { Refineries Sold }\end{array}$ & $\begin{array}{c}\text { Percent of } \\
\text { U.S. Total }\end{array}$ & $\begin{array}{c}\text { Combined Refineries Sold } \\
\text { (thousand barrels } \\
\text { per day) }\end{array}$ & $\begin{array}{c}\text { Percent of } \\
\text { U.S. Total }\end{array}$ \\
\hline & & & & \\
1980 & 6 & 1.9 & 204 & 1.1 \\
1981 & 20 & 6.2 & 885 & 4.8 \\
1982 & 9 & 3.0 & 719 & 5.3 \\
1983 & 10 & 3.9 & 894 & 3.4 \\
1984 & 15 & 6.1 & 548 & 7.9 \\
1985 & 13 & 5.8 & 1,236 & 4.8 \\
1986 & 20 & 9.3 & 743 & 1.9 \\
1987 & 9 & 4.1 & 293 & 10.2 \\
1988 & 21 & 9.9 & 1.617 & 2.5 \\
1989 & 5 & 2.4 & 387 & - \\
Total & 128 & - & 7.525 & -1 \\
\hline
\end{tabular}

a Crude distillation capacity as of January 1 in each year.

Note: Totals may not equal sum of components due to independent rounding.

Sources: Energy Information Administration, Energy Data Report, "Petroleum Refineries in the United States and U.S. Territories." and

Petroleum Supply Annual 1981-1989. 
percent, or 4.2 million barrels per day of crude distillation capacity (Figure 22). More than half of the increase in forcign-affiliates' share of U.S. crude distillation capacity in the 1980's occurred between 1985 and 1988. Most of the increase during this period can be accounted for by several large joint ventures or acquisitions, such as the $50-50$ joint venture of the State oil company Petroleos de Venezuela SA (PDVSA) with Southland Corporation in 1986; BP Americas' acquisition of Standard Oil Company of Ohio in 1988; and the formation of Star Enterprise, a 50-50 joint venture between Texaco Inc., and the State oil company of Saudi Arabia (Table 11).
Figure 22. Percent of U.S. Crude OII DIstlllation Capaclty by Forelgn-Afflllated and U.S. Owned Companies, 1980-1988

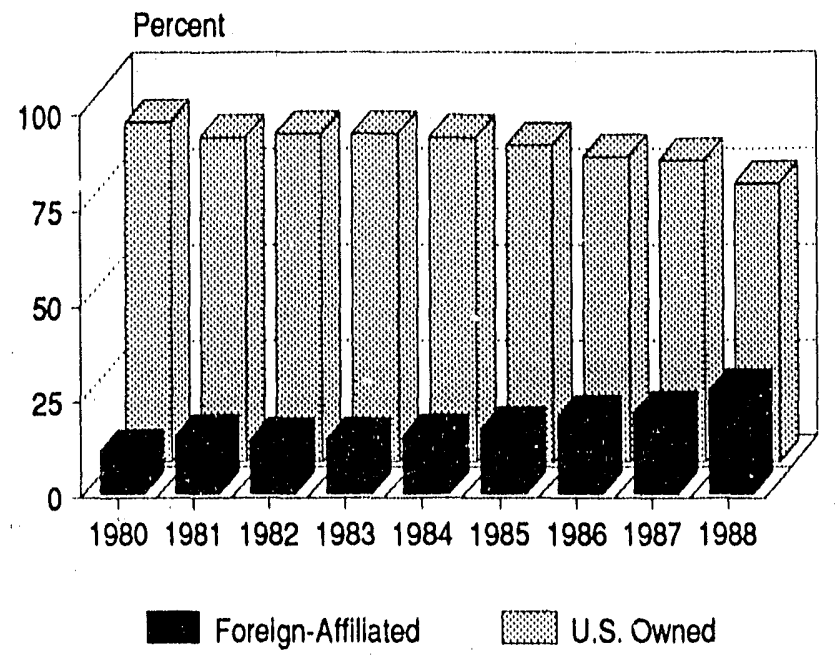

Source: Energy Information Administration, Profiles of Foreign Direct Investment in U.S. Energy 1983 and 1988.

See Table C20 in Appendix C for corresponding data.

Table 11. Selected Forelgn-Affillated U.S. Refinery Ownershlp, 1980-1990

\begin{tabular}{|c|c|c|c|c|}
\hline U.S. Company & $\begin{array}{l}\text { Foreign-Affiliated } \\
\text { Company (Country\%) }\end{array}$ & Refinery Location & $\begin{array}{l}\text { Crude Distillation } \\
\text { Capacity(thousand } \\
\text { barrels per day) }\end{array}$ & $\begin{array}{c}\text { Date of } \\
\text { Sale }\end{array}$ \\
\hline Southland Corp. & $\begin{array}{l}\text { Petroleos de Venezuela } \\
\text { (Venezuela 50\%) }\end{array}$ & Lake Charles, LA & 320 & $10 / 86$ \\
\hline Champlin Petro. Co. & $\begin{array}{l}\text { Petroleos de Venezuela } \\
\text { (Venezuela } 50 \% \text { ) }\end{array}$ & Corpus Christi, TX & 155 & $4 / 87$ \\
\hline Texaco Inc. & $\begin{array}{l}\text { Saudi Refining Inc. } \\
\text { (Saudi Arabia } 50 \% \text { ) }\end{array}$ & $\begin{array}{l}\text { Delaware City, DE } \\
\text { Port Arthur, TX } \\
\text { Convent, LA }\end{array}$ & $\begin{array}{l}140 \\
250 \\
225\end{array}$ & $\begin{array}{l}11 / 88 \\
11 / 88 \\
11 / 88\end{array}$ \\
\hline Coastal Corp. & $\begin{array}{l}\text { Sinochem } \\
\text { (China 50\%) }\end{array}$ & Hercules, CA & 55 & $12 / 88$ \\
\hline Union Pacific Corp. & $\begin{array}{l}\text { American Ultramar LTD } \\
\text { (United Kingdom 100\%) }\end{array}$ & Wilmington, $\mathrm{CA}$ & 65 & $12 / 88$ \\
\hline Champlin Petro. Co. & $\begin{array}{l}\text { Petroleos de Venezuela } \\
\text { (Venezuela } 100 \% \text { ) }\end{array}$ & Corpus Christi, TX & 130 & $12 / 88$ \\
\hline Mobil Oil Corp. & $\begin{array}{l}\text { BP America } \\
\text { (United Kingdom 100\%) }\end{array}$ & Ferndale, WA & 77 & $12 / 88$ \\
\hline UNOCAL Corp. & $\begin{array}{l}\text { Petroleos de Venezuela } \\
\text { (Venezuela } 50 \% \text { ) }\end{array}$ & Lemont, IL & 147 & $11 / 89$ \\
\hline
\end{tabular}

Note: Petroleos de Venezuela acquired 50 percent interest in the Champlin Petroleum Company, Corpus Christi, Texas, refinery in April 1987. In December 1988, they acquired the remaining 50 percent.

Sources: Energy Information Administration, Profiles of Foreign Investment in U.S. Energy 1988, Table A1, p. 31, and predecessor report; Petroleum Supply Annual 1981-1989. 


\section{Refinery Outlook for the 1990's}

\section{Introduction}

The U.S. refining industry has faced many technical and economic challenges during the 1980's. These challenges were brought about by changes in the demand for petrolcum products, government regulations, and deregulation. Of major significance was the elimination of crude oil price and allocation controls, as well as, the advent of environmental initiatives, such as, changes to the specifications of motor gasoline. In the 1990's, the refining industry will face similar challenges. Some of the challenges refiners are expected to face during the 1990's are:

- Tighter environmental regulations, stricter product specifications, and a growing product demand (Figure 23).

\section{Figure 23. Petroleum Product Supplled,} 1980-2000

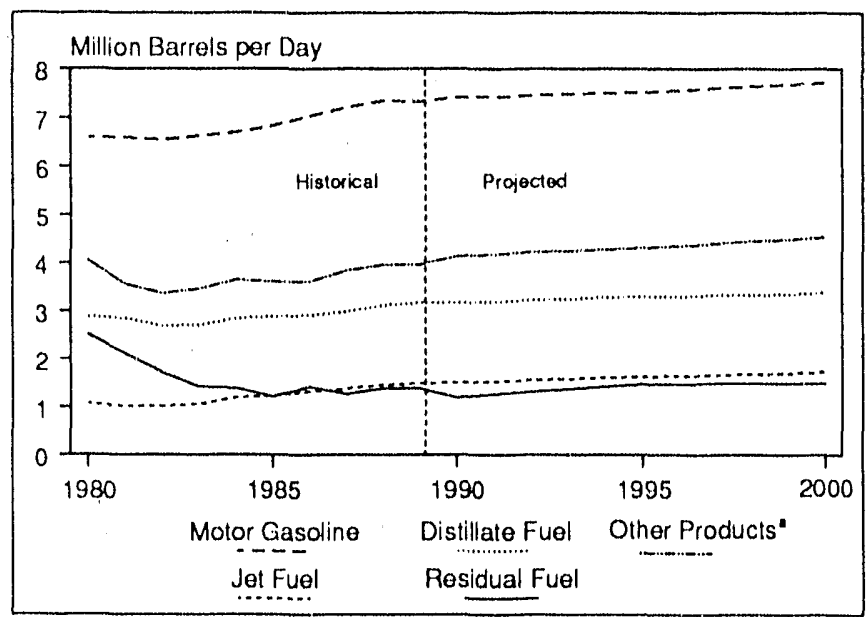

a Other Products include natural gas liquids, aviation gasoline, kerosene, petrochemical feedstocks, special naphtha, lubricants, waxes, petroleum coke, still gas, and miscellaneous products.

Sources: 1980-1985: Energy Information Administration, Annual Energy Review, 1988; 1990-2000: Annual Energy Outlook, 1990.

See Table C21 in Appendix C for corresponding data.
- The projected increase in the demand for petrolcum products between 1989 and the year 2000. This increase of 1.5 million barrels per day will be impossible to mect through current U.S. refining capabilitics without significant capacity increases from either $\mathrm{cx}$ pansions at existing facilities or new refinery construction.

- Environmental regulations governing plant location. Although the economic factors affecting refinery expansion decisions improved during the late 1980's, cnvironmental regulations are expected to discourage any new refinery construction. Increases in capacity will probably occur, first through debottlenecking of existing units, after which refiners will consider the large capital investment needed to build additional units at existing refincries.

- Continued demand for light products. Demand is expected to continue to dominate and grow through the 1990 's, leading to the requirement for greater utilization of downstream processes units.

- Increased crude oil costs during the 1990's. Refined product prices are also projected to increase, but at a slower rate. This will place added pressure on refiners to cut costs in other areas in order to maintain profitability.

\section{Refinery Utilization and Operations}

The operable refincry utilization rate increased during the 1980 's and averaged 86.3 percent during 1989. This was the highest rate since the late 1970's, when refinery utilization rates frequently exceeded 90 percent. By the year 2000), 
average annual refinery utilization rates are likely to again exceed 90 percent if capacity does not increase. ${ }^{41}$ Maintenance of gasoline octane ratings will become more difficult in the 1990's with the elimination of lead from the gasoline pool. Additional environmental regulations are expected to limit levels of octane enhancing aromatics, especially benzene, in gasoline; Phase II of the EPA summer gasoline volatility reductions will result in less normal butane, which boosts both octane rating and volume, being blended into gasoline during the 1990's. Inputs of octane enhancing gasoline additives, such as the oxygenate MTBE, are expected to increase during the 1990's. ${ }^{42}$

The future of oxygenate blending into motor gasoline is related to the availability and price of natural gas to produce methanol, a major fecdstock for MTBE production. Another oxygenate, ETBE, could play a role in gasoline blending, but high costs for producing ETBE make it uncompetitive with MTBE.

One possible alternative to the use of oxygenates for octane enhancement is the additive methylcyclopentadienyl manganese tricarbonyl (MMT). This additive has been used in Canada since 1957, but was banned in the United States in 1977 by provisions of the Clean Air Act. It was banned because of increases in hydrocarbon emissions from automobile tailpipes. Advocates of MMT are currently attempting to gain a waiver from EPA to permit its use in the United States. These advocates contend that MMT would allow refiners to reduce the use of other harmful octane enhancing additives, such as aromatics which may pose cancer risks to humans, by substituting small amounts of MMT. They also point out that MMT could help overcome shortages of MTBE for boosting octane numbers because the amount of MMT required would be extremely small (1/32 gram of MMT per gallon of motor gasoline can boost octane $1(R+M) / 2$ number $)$.

Mecting petroleum product demand during the 1990's will be further complicated by increased crude oil sulfur content, due largely to greater reliance on crude oil imported from Arab OPEC sources. ${ }^{43}$ The combination of high sulfur crude oil inputs and environmental regulations limiting product sulfur levels will force refiners to expand hydrotreating capacity or face processing bottlenecks in desulfurization units. Refiners began large scale investment in hydrotreating capacity during 1988.

In the 1990's, refiners must prepare for shifting sources of' crude oil supply. Regional refiners dependent on locally produced crude oil must find ways to replace these sources. Many of these regional refineries are configured for local crude oils and their operators will face decisions about new refining or transportation investments.

\section{Potential for Expansion of Refinery Capacity}

During the carly 1980 's, plans to expand refining capacity were heavily influenced by falling demand for petroleum products, high crude oil costs, and changes in regulatory policies which made small refineries less competitive. These factors contributed to reductions in the return on investment in the refining sector. ${ }^{44}$ As a result, there was little incentive to expand refinery distillation capacity, and many refineries were closed, causing U.S. operable distillation capacity to fall significantly.

During the 1990's, refinery expansion plans will continue, to be affected by returns on investment, which improved during the late 1980's, and demand for petrolcum products which is projected to increase through 2000 . Although economic factors affecting refinery expansion decisions show improvement, environmental regulations are expected to significantly increase costs involved in refinery expansion.

The impact of environmental regulations on refinery expansion has been substantial over the past 20 years. Between 1970 and 1990, at least 20 refineries proposed for the U.S. East Coast were rejected by State and local jurisdictions for environmental reasons. ${ }^{45}$ As environmental regulations tighten, the possibility that new refining capacity will be constructed in the U.S. will diminish. Additions to refining capacily are expected to come from construction of new processing units at existing refineries and modifications to existing units to take advantage of technological advances.

\footnotetext{
${ }^{41}$ Iinergy Information Administration, Annual Oullook for Oil and Gas 1989, Washington, DC, p. 26.

42 Energy Information Administration, Annual Energy Oullook 1990, Washington, DC, p. 21.

43 "Refining Report," The Oil Daily (February 26, 1990), p. B2.

44 Encrgy Information Administration, Annual Energy Review 1988, Washington, DC, p. 80.

45 The U.S. Congress House Conmittee on Energy and Commerce, Subcommittee on Oversight and Investigations. Testimony at a hearing on the National Energy Strategy by Secretary of Energy James D. Watkins, Admiral, USN (Retired), A pril 23, 1990.
} 
When signed into law, amendments to the Clean Air Act (CAA) will have a significant impact on refinery expansion plans. Costs to refiners for environmental compliance for plant equipment and development of reformulated or alternative fuels could be substantial, but the final impact of CAA amendments on the refining industry will depend on the focus of regulations which follow the amendments.

If regulations focus on process-unit emissions (pollutants from refinery processing units), then U.S. refiners could be faced with prohibitive costs in order to reduce these emissions from existing process units. In this case, the refining industry may expand capacity in foreign countries where less restrictive environmental regulations will lower construction and operating costs. Under this scenario, shortfalls in domestic refinery production would be offset by higher imports of refined product.

If the focus of environmental regulations is on fuel specifications, U.S. and foreign refiners will bear the costs of meeting the U.S. environmental requirements. A focus on fucls may provide U.S. refiners with competitive advantages because they have a large lead over foreign refiners in sophisticated provess equipment necessary to meet clean fuels specifications. This would tend to shift product imports towards unfinished oils and away from finished products.

Environmental regulations will increase costs of refinery expansion, and may even preclude some projects, but these same regulations will make it necessary for refiners to invest in pollution control equipment and in capacity for downstream processing and for production of fuel additives such as MTBE.

Industry estimates suggest that investments for environmental compliance by the refining industry will be substantial during the 1990's. For example, the president of ARCO las recommended that his firm make investments of $\$ 2$ billion by 1995 in order to make reformulated motor gasoline. ${ }^{46}$ Amoco expects to spend $\$ 30$ million by 1992 in order to produce motor gasoline to comply with Phase II RVP regulations, and scoping studies by Amoco indicate the firm may have to invest as much as $\$ 1$ billion in order to comply with expected future environmental resulations affecting process unit emissions and fucl specifications. ${ }^{47}$ In an effort to quantify the potential impact of environmental regulations on the refining industry as a whole, the Chairman of Crown Central Petroleum Company estimated that environmental costs to the refining industry could exceed $\$ 18$ billion per year. ${ }^{48}$ Considerable uncertainty exists as to the investment requirements which will be necessary to comply with future environmental regulations, but the estimated cost clearly shows that industry expects investments for environmental compliance to be substantial.

Hydrocrackers are very expensive to build (approximately $\$ 4,000$ for each barrel per stream day of capacity), ${ }^{49}$ and they are costly to operate due to the large amounts of expensive hydrogen consumed during the process. In addition, of ten a hydrogen plant must be built at the refinery in order to supply the vast amounts of hydrogen needed, although hydrogen is also generated internally at the refinery from catalytic reforming. However, since these units produce high-quality light products from heavy oils, refirers who could afford the initial capital investment built them in order to comply with environmental regulations requiring cleaner fuels. As available crude supplies get heavier, more heavy residuals must be processed to maintain and/or increase the volume of light products. Therefore, more hydrocrackers will be needed. Because of the expense, only those companies with sufficient revenue will be able to afford to build and operate them.

Catalytic cracking capacity is expected to grow only slightly in the years ahead. Revamps to these units will improve, and refiners will be running them at higher temperatures because higher temperatures raise the alkylate yield, an excellent gasoline feedstock. As refiners raise the amount of alkylate yield from catalytic cracking, they will need to build more alkylation units to accommodate this feed and to produce larger quantities of high-octane gasoline. However, refiners may have problems obtaining permits to build additional alkylation capacity because this process uses hydrofluoric acid which has very serious environmental implications.

\footnotetext{
46 "ARCO Official Recornmends $\$ 2$ billion Commitment to Future of Company's Reformulated Gasolines," The Oil Daily (December 15, 1989), p.1 and 8 .

47 "More U.S. Refiners to Offer Low Emission Gasoline," Oil and Gas Journal (December 4, 1989), p. 31.

48 "Environmental Worries Dominate NES Hearings," Oil and Gas Journal (December 18, 1989), p. 18.

${ }^{49}$ Refining Process Services, Introduction to Petroleum Refining Processing, prepared for the U.S. Department of Energy (Cheswick, Pennsylvania, 1990).
} 


\section{Appendices}




\section{A. Petroleum Refinery Processes}

\section{Introduction}

Through various physical and chemical means, petroleum refineries extract and enhance the valuable components of crude oil to produce a large array of marketable petroleum products (Figure A1). Primitive by today's standards, the carlicst petroleum refineries - which were really little more than stills - were designed to extract kerosene from crude oil for use as lamp oil and petroleum greases. Whatever petroleum remained, including gasoline, was treated as waste. The advent of the internal combustion engine and subsequent explosion in automotive transport in the (iirst half of the th century, however, forced refiners to expand capacity and to incorporate new refining technologies. By the early 1920's, the automobile and airplane were firmly established in the United States as major modes of transportation. Along with an expansion in capacity, refiners developed new methods to increase yields of gasoline and other motor fuels. After the Second World War, rapid growth in jet fuel consumption also placed new demands on the domestic refining sector. Today, refiners produce a wide range of fuels and specialty oils used in transportation, industry, electricity generation, heating, and petrochemical production, and in thousands of other uses. These modern facilities employ a variety of technologies to squecze the most out of a barrel of crude oil and to provide the flexibility required to meet shifting seasonal product demand patterns.

\section{Characteristics of Crude Oil}

Crude oil is not a homogenous substance but is a collection of an almost countless varicty of hydrocarbons. A hydrocarbon is a molecule that is comprised of at least one atom of carbon in chemical association with hydrogen atoms. As many as four hydrogen atoms may form covalent bonds with an atom of carbon. Light hydrocarbons are those that have relatively few carbon atoms to which hydrogen atoms may attach. Methane, for example, is the lightest hydrocarbon. It is composed of one carbon atom and four hydrogen atoms. Heavier hydrocarbon molecules have relatively more carbon atoms to which hydrogen atoms may bond some with as many as 85 - and there are millions of possible hydrocarbon combinations. Cetane, for example, is composed of 16 carbon atoms and 34 hydrogen atoms.

All crude oils consist primarily of hydrocarbons in paraffin (alkane), cyclo-alkane, and aromatic forms in association with small amounts of sulfur, brine, nitrogen, oxygen, minerals, and metals. However, no two crude oils are exactly the same, even those from the same producing formation. There are thousands of crude oils that differ in color, viscosity (tendency to flow), sulfur, and metal and mineral content. Crude oils, however, are often clumped into a few major categories based on certain characteristics and qualities. For instance, crude oils are classified based on the presence or absence of particular kinds of hydrocarbons. Asphalt-based crude oils contain significant portions of asphaltic hydrocarbons. Paraffin-based crude oils, on the other hand, yield large amounts of wax and lubricating oils, and contain a minimal amount of asphalt. Those crude oils which contain large portions of both wax and asphalt are mixed-base crude oils. Two other parameters of interest to refiners are the density, or gravity, of a crude oil and its sulfur content.

API Gravity - The American Petroleum Institute (API), a major petroleum industry trade association, has developed a standard industry measure of crude oil quality based on its weight, or density. Mcasured in degrees, API gravity represents the same mass-to-volume relationship as specific gravity but uses a different and inverted scale. The higher the degree of API gravity, the lighter the oil. As an example, under the API system, motor gasoline has a gravity of about 60 degrees. Water, which is denser, or heavier, than motor gasoline, has an API gravity of only 10 degrees. Crude oils with relatively large amounts of small, simple hydrocarbons are called "light" crude oils, while those with significant amounts of large, complex hydrocarbons are referred to as "heavy" crude oils. The API gravity of crude oils from different parts of the world varies greatly. Typically, crude oils with an API gravity of 30 degrees or more are considered light, high-quality crude oils. These oils are ideal for producing motor gasoline and other high-value light products with minimal processing costs. Lower-quality 
Figure A1. 1989 Refinery Ylelds (Percent) and Petroleum Product Uses

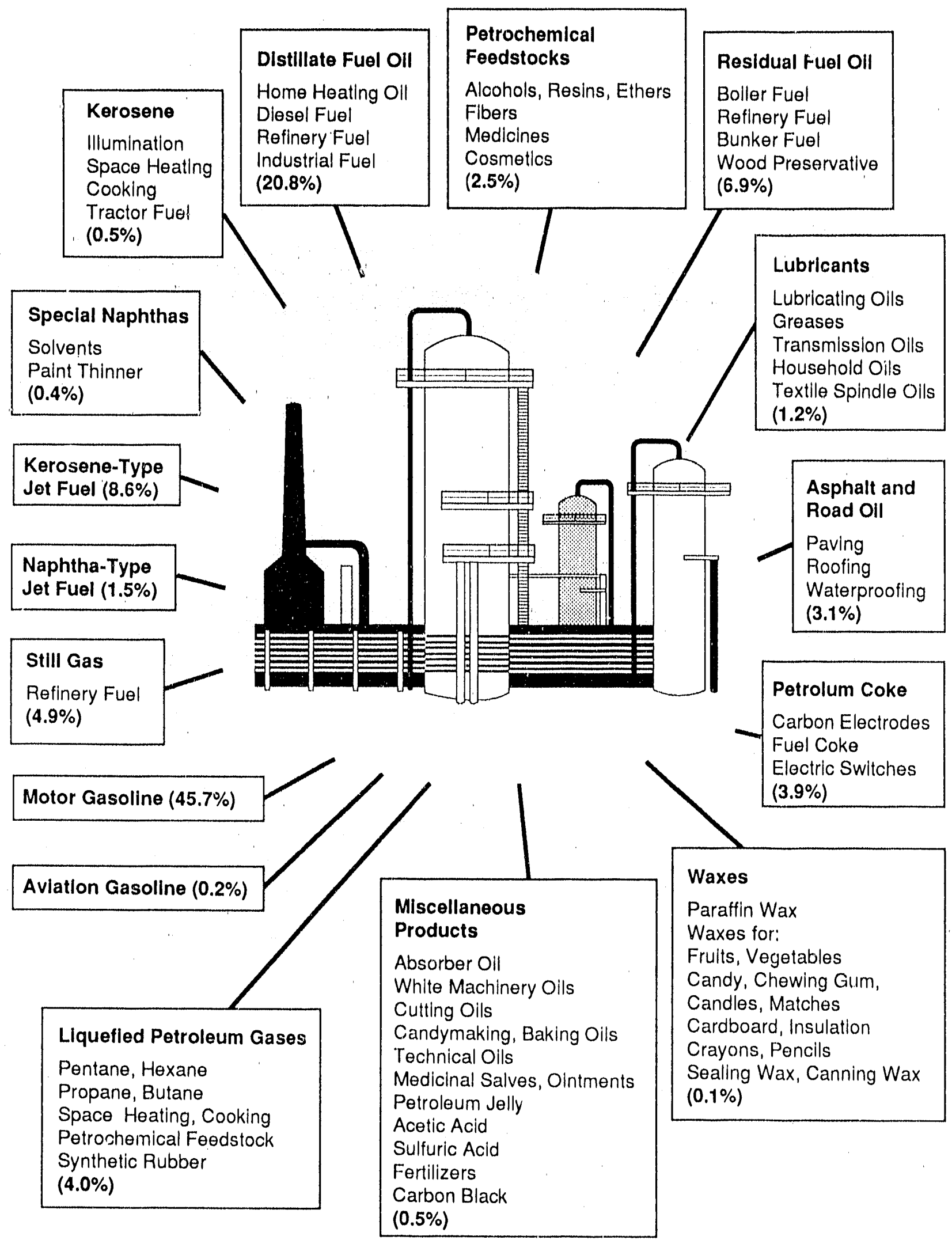

Source: Energy Information Administration, Office of Oil and Gas. 
heavy crude oils of under 30 degrees API gravity normally yicld higher quantities of less valuable heavy fuels. Motor gasoline and other high-quality products can be produced from heavy crude oils, but this requires additional and more severe processing.

Sulfur Content - The amount of sulfur present in crude oil is another important characteristic of crude oil. The sulfur content of many fuels is regulated by Federal and State Governments to reduce atmospheric pollution. In iddition to the health and environme ital risks of sulfur, corrosive forms of sulfur can damage refinery processing units and other forms can affect the odor and explosive qualities of finished products such as lubricants and motor gasoline. For these and other reasons, refiners extract as much sulfur as possible from crude oil. The process of extracting sulfur is termed "desulfurization" and entails a number of physical or chemical techniques, depending on the type of sulfur compounds present and their quantity. Sulfur is present in crude oil in a variety of different compounds, including thiols, thia cyclo thiols, thiophenes, benzothiophenes, and even more complex ring structures. Its content can range anywhere from less than 0.1 percent to about 7.0 percent, by weight. Crude oils with a low sulfur content (less than 0.5 percent, by weight) are said to be "sweet," while those with a high sulfur content (greater than 1.0 percent, by weight) are said to be "sour." Crude oil with sulfur contents between 0.5 percent and 1.0 percent, by weight are considered "medium" grade crude oils.

The type of crude oil a refinery can process depends on the processing units it has and the desired range of end products. Complex and very complex refineries, which have a variety of processing and treatment options, have more flexibility in choosing a crude oil than do relatively simple refineries with limited processing facilities. Refineries which lack desulfurization equipment, for instance, will be compelled to operate using sweet, low sulfur crude oils. Changes in refinery complexity are often prompted by the availability of certain types of crude oil. The refinery retrofitting and upgrading performed by West Coast refiners in response to the influx of relatively sour crude oil from Alaska in the late 1970's is a good example of this occurrence.

While many relatively simple refineries still operate in the United States, most domestic production capacity is part of a complex refining facility. This processing flexibility allows the domestic refining sector to effectively respond to changes in product supply and demand by shifting product mix and to do so economically. The particular products produced at a refinery are referred to as that refinery's "slate," and these can vary among refineries and with shifting seasonal demand. Thus, refineries produce more motor gasoline during the spring and summer months, the peaks demand months for this product, than they do during the late fall and winter, a time when more fuel oils for heating are required.

\section{Refining Processes}

Although refiners have a number of processing options available to them, refinery operations can be divided into four general categorics: separation of hydrocarbons; conversion of hydrocarbon molecules; treatment of hydrocarbon products; and, blending of hydrocarbon products. Not all refineries perform all of these operations all the time, but by employing these methods refiners are able to unlock the full potential of crude oil (Figure A-2).

\section{Separation of Crude Oil Fractions}

The first phase in the refining process involves separating the crude oil or unfinished oils into different hydrocarbon groups, or "fractions." There are many ways to do this, including solvent extraction, absorption, and crystallization, but fractional distillation is the most common approach used. Distillation takes advantage of the fact that each of the different hydrocarbon compounds that comprise crude oil has a characteristic boiling point. These can range anywhere irom less than minus 90 degrees Fahrenheit to over 800 degrees Fahrenheit. The boiling point of a liquid is the temperature at which it vaporizes when heated. The boiling point is also the temperature at which a vapor condenses when cooled. By heating crude oil until all or most of it vaporizes and then cooling the hydrocarbon vapor to specific temperatures, refiners can separate out the various hydrocarbon components. It is not practical to isolate each of the myriad hydrocarbon components, so instead refiners "cut" the crude into groups of hydroe arbons with particular boiling-point ranges.

The separating of crude oil into specific hydrocarbon groups, or "fractions," is the central feature of the distillation process, and the products produced are called straightrun liquids. There are two major types of distillation employed by refineries: atmospheric and vacuum.

Atmospheric Distillation - Atmospheric distillation is the most widely used method for separating crude oil fractions. The utilization rates at which these units are operated is the most commonly used barometer of the "general state" of a refinery or when combined the refining industries operational stalus. During atmospheric distillation, crude oil which has been heated to as much as 750 degrees Fahrenheit is pumped into the bottom of a distillation tower under 
Figure A2. SImplifled Flow Chart of a Complex Refinery

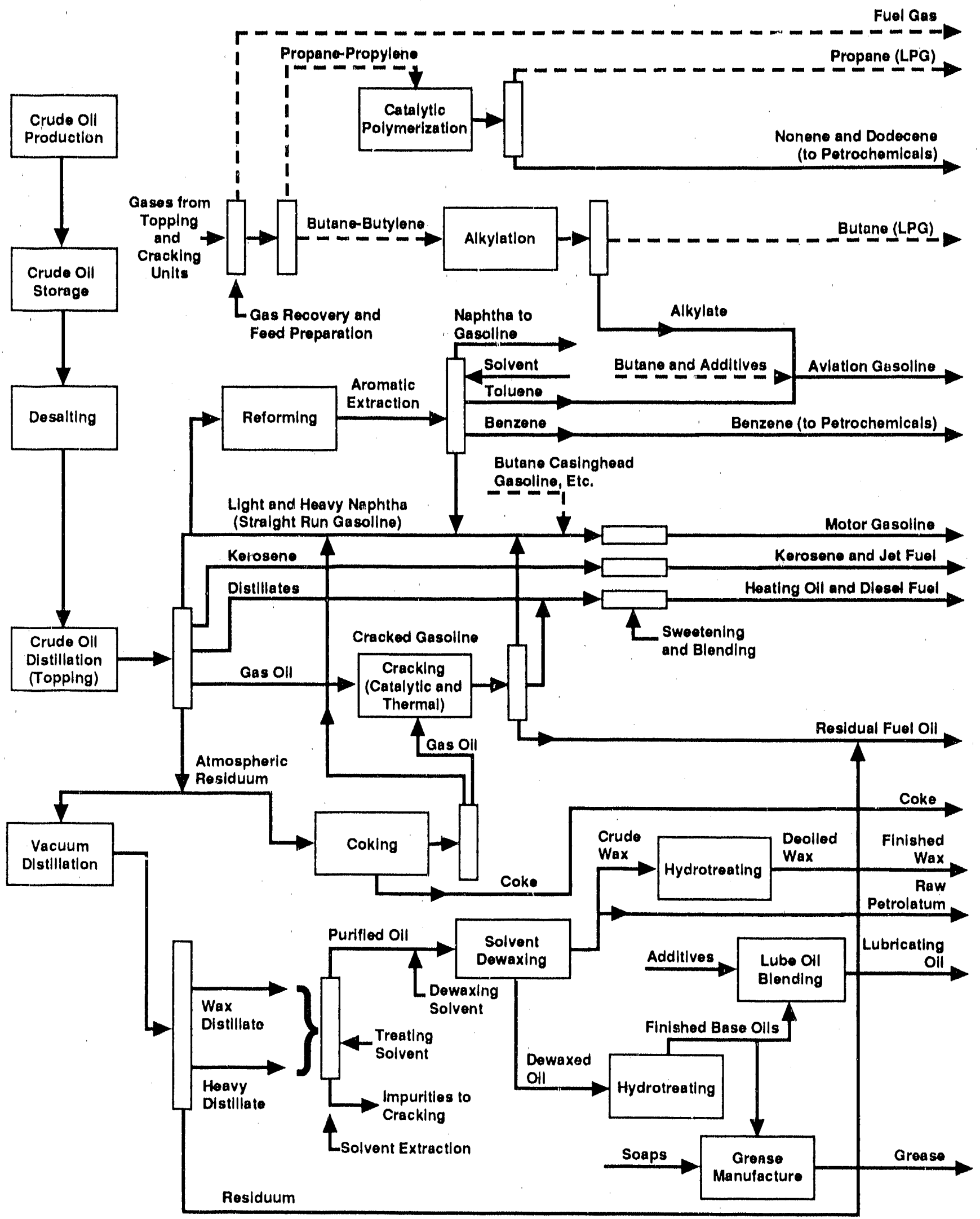

Source: National Petroleum Councll, U.S. Petroleum Refining, Appendix C. 
atmospheric pressure. The hydrocarbon vapors rise in the tower and pass through a series of trays located at different levels. The distillation tower is hottest at the bottom of the lower and is progressively cooler as it rises. The trays collect condensing vapor and are equipped with "bubble caps." The bubble caps force the rising vapor to percolate through the condensed liquid already on the tray which cools the hydrocarbon vapor, condensing some of it. The trays also are equipped with downcomers which transfer overflow to the next tray below. At specific levels throughout the tower, sidedrawers remove the liquid collected on the trays which is then sent to other parts of the refinery for further processing.

Products with the lowest boiling points condense and collect at the top of the tower while products with higher boiling points condense and are drawn off at the bottom. At the top of the tower, butanes and lighter gases are recovered and either used as fuel or sent to fractionators. At the next lower level, straight run gasoline is drawn off. Further down the tower, naphtha and kerosene are extracted. Next down are the light and heavy gas oils. At the bottom, heavy straight-run residue anci asphalt are drawn off (Figure A-3).

Vacuum Distillation - Some fractions of crude oil boil at such high temperatures at atmospheric pressure that the hydrocarbon molecules break apart before they vaporize. Uncontrolled break-up of heavy hydrocarbon molecul s reduces the ability of a refinery to maximize production of high-value light products. In addition, the application of excessive heat to the oil can damage distillation equipment and lead to the formation of coke deposits which must be removed. To avoid such heat induced chemical degeneration, refiners employ vacuum distillation for particularly heavy hydrocarbon fractions. The boiling point of a liquid is, among other things, a function of atmospheric pressure. A liquid vaporizes when its internal pressure equals the pressure of the overlying air. Thus, reducing the atmospheric pressure reduces the boiling point temperature of a liquid. Vacuum distillation (also known as vacuum flashing) lowers the pressure within the distillation vessel, permitting heavy hydrocarbon fractions to be separated at lower temperatures. Straight-run residue and distillate bottoms from atmospheric units usually make up the feed for vacuum units. Several streams can be drawn from a vacuum unit, including light and heavy distillates and "flasher" bottoms.

\section{Conversion of Hydrocarbon Molecules}

Kclatively small amounts of motor gasoline range and other light fucls are produced through distillation alone (10 to 25 percent, depending on the crude oil quality). The growing demand for these fucls in the 1920's and 1930's spurred refiners to develop new technologies designed to increase the yicld of motor gasoline and its quality. The processes they developed convert hydrocarbons not found in the gasoline range into more valuable, gasoline-range hydrocarbons. These "downstream" refining processes fall into three general categories: cracking hydrocarbon molecules; combining hydrocarbon molecules; and, rearranging hydrocarbon molecules. Each operation requires specific equipment and yields different products.

Cracking of Hydrocarbon Molecules - One method refiners use to increase the yicld of gasoline is cracking. Cracking is a process by which large, heavy hydrocarbon molecules are broken down, or "cracked," into smaller, gasoline range hydrocarbon molecules. Refiners discovered that cracking raises the yicld of motor gasoline and improves its quality. Cracking can be achieved either through the application of heat or the use of a catalyst. The main types of cracking operations are thermal cracking, delayed and fluid coking, flexicoking, catalytic cracking, and catalytic hydrocracking.

Thermal cracking was developed by William Burton and was used in U.S. refineries as early as 1913. The primary feedstocks for thermal operations are residuum and heavy gas oils. The feedstock is heated to a high temperature and pumped into the reaction vessel where it is subjected to increasing pressure. The combination of high temperature and pressure causes some of the bonds holding the hydrocarbon molecules to break. This mixture of cracked hydrocarbons is then sent to a flash chamber where the various fractions are separated. Butanes, gasoline blend stock, naphtha, and gas oils are the main products derived from thermal cracking units. Delayed and fluid coking and flexicoking are more intensive thermal cracking operations. A characteristic of coking operations is the deposition of petroleum coke, a solid, coal-like substance derived from heavy hydrocarbons, on the bottom of the coking drum. Coking produces quantities of light hydrocarbon liquids and refinery gases.

Catalytic cracking, introduced by Eugene Houdry in France, made its way to the United States in 1937. Catalytic cracking is in many respects similar to thermal cracking except that the reaction occurs in the presence of a catalyst. A catalyst is a substance that accelerates the rate at which a chemical reaction occurs without being altered in any way by the reaction. Alumina and processed clay are two catalysts regularly used in catalytic cracking units. Heavy gas oil is the principal feedstock used in catalytic cracking and when processed yields liquefied refinery gases, gasoline blend stock, naphtha, light cycle oil, and other light-end products. Normally, about 50 to 60 percent of the output of a catalytic cracker is gasoline grade product with good anti-knock characteristics. 
Figure A3. Crude OIl Distillation

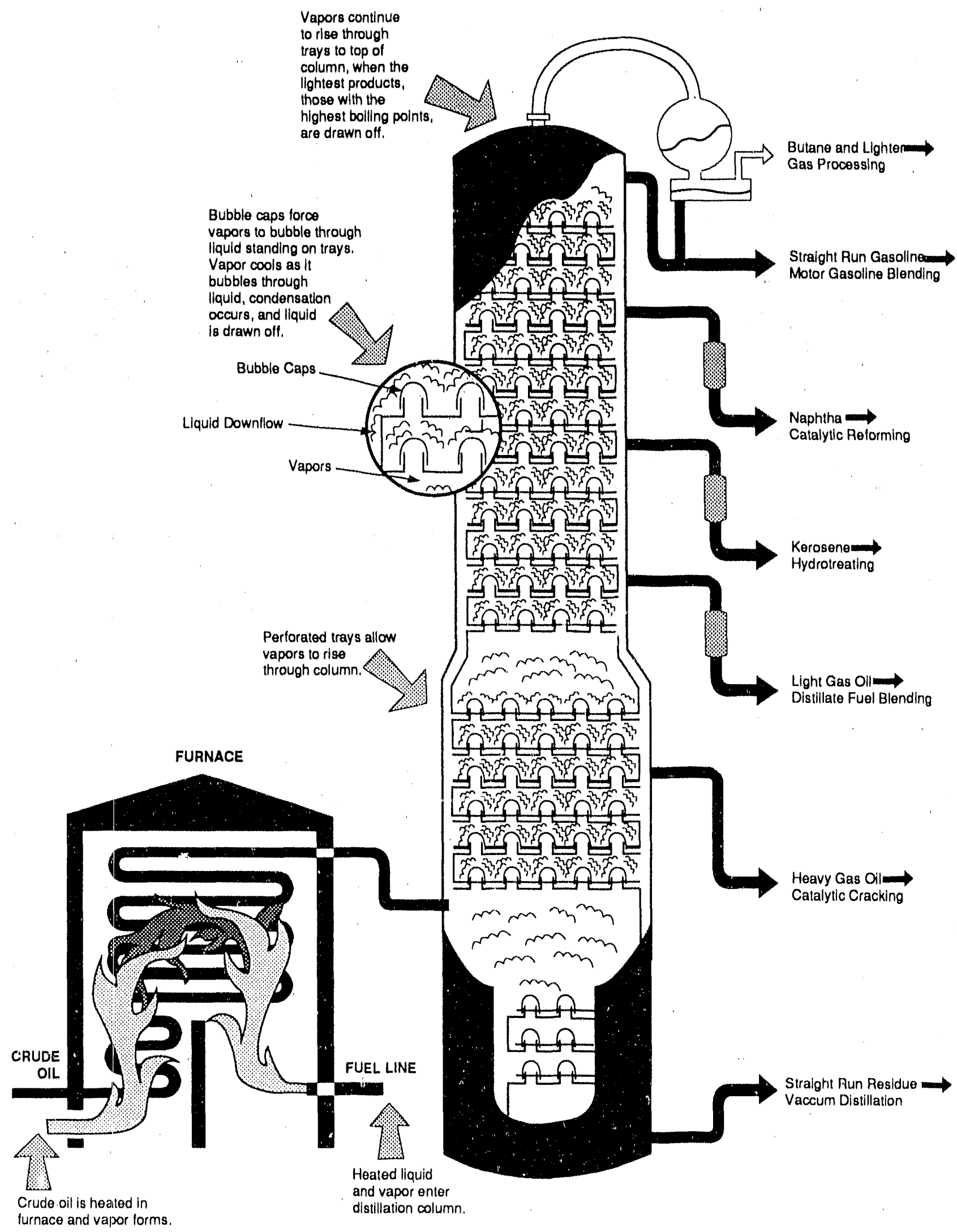

Source: Energy Information Administration, Office of Oil and Gas. 
Catalytic hydrocracking produces light products from lower quality oils that would normally be blended into distillate fuel oil. The process is similar to catalytic cracking except that hydrogen is added to the oil mixture. Hydrocracking generates high-quality, low-sulfur stocks for blending into motor gasoline, jet fuel, and other products. It is particularly useful when running sour feedstocks because the hydrogen combines with the sulfur to form hydrogen sulfide, which can then easily be removed from the refinery stream. Hydrocracking capacity is especially uscful for maximizing refinery yields of motor gasoline and jet fuels during peak demand periods for these products, and minimizing yields of less desirable products such as residual fuel oil.

Combining Hydrocarbon Molecules - Combining operations link two or more hydrocarbon molecules to form a larger molecule. In this way, gases can be converted into a liquid and used as an additive to motor gasoline and other motor fuels. Nearly all refinery operations yield at least some refinery gases, and these can be divided into either paraffins or olefins. The paraffin series of gases includes methane, ethane, propane, normal butane, and isobutane. Each of these hydrocarbon gases is said to be saturated because their carbon atoms carry a full complement of hydrogen atoms. However, gases of the olefin series, which includes ethylene, propylene, butylene, and isobutylene, do not have a full complement of hydrogen aioms. This means that there is at least one double bond linking a hydrogen atom with a carbon atom in the molecule. This characteristic, double-bonding, makes olefins less stable, and, thus, more reactive than paraffins. As such, olefins are ideally suited for combining operations. Two common procedures for combining hydrocarbon molecules are alkylation and polymerization.

Alkylation is a process which combines a light olefin, primarily propylene and butylene, with a molecule of the paraffin isobutane. The reaction is aided by a catalyst. The product of this operation is alkylate, one of the highestquality components in motor gasoline. Alkylation units can also combinc a molecule of an olefin with the paraffins normal butane and isobutane to generate iso-octane, a valuable blending component and the measure of a fucls octane rating.

Polymerization is a technique which employs a catalyst and links together molecules of olefin gases produced during thermal and catalytic cracking operations. High-octane motor gasoline blend stock is produced from these reactions.

Rearranging Hydrocarbon Molecules - Rearranging operations alter the original structure of a molecule, producing a nicw mulcciatic with differcnit characteristics from the original but with the same number of carbon atoms. Catalytic reforming and isomerization are two of the most commonly used techniques for rearranging hydrocarbons.

Catalytic reforming is a process which uses heat and a catalysi to convert straight run naphthas into primarily aromatic compounds. Low-grade naphtha is converted in a catalytically induced reaction to a high-quality blending component called reformate. Ilydrogen also is freed in these reactions and is recovered for use in hydrocracking units. The aromatics benzene, toluene, and xylene also can be used as petrochemical feedstocks.

Isomerization is a process in which straight-chained hydrocarbon molecules are converted to branch-chained molecules with the same chemical composition. This reaction is advanced through the use of a specially prepared platinum catalyst. The normal (straight-chained) paraffins butane, pentanc, and hexane provide the feedstocks to isomerization units and are changed into the (branchedchained) isoparaffins isobutane, isopentane, and isohexane. Isobutane is used mainly as an alkylation feedstock; isopentane and isohexane are blended into motor gasoline and aviation fuel.

\section{Treatment of Hydrocarbon Molecules}

With the increased emphasis on producing higher yields of high-octane gasolines and low-sulfur fuel oil, it is necessary to upgrade the components used in gasoline, aviation fuel, and fuel oil blending. Blend stocks produced directly from atmospheric distillation and thermal cracking often contain unacceptable amounts of sulfur, nitrogen, and other impurities. High quantities of sulfur, for example, foul refinery equipment, inhibit the effectiveness of some anti-knock additives, increase engine maintenance, and contribute to increased atmospheric concentrations of sulfur dioxide. Two commonly used methods of removing impurities from petroleum products are hydrotreating and chemical treating.

Hydrotreating - Liquid hydrocarbon streams composed of hexane and heavier molecules usually undergo hydrotreating. Hydroireating removes sulfur, nitrogen, and heavy metals which might be present in the feedstock. Within the hydrotreating unit, a number of chemical reactions occur in the presence of hydrogen. A pelleted catalyst is used to accelerate these reactions. During treatment, hydrogen atoms bond with the sulfur in the oil stream, forming hydrogen sulfide. Ammonia is another by-product of hydrotreating. It is produced by combining hydrogen atoms with some of the nitrogen present in the hydrocarbon feedstock. Metals attach themselves to the catalysts and are removed when the catalyst is recycled. In addition to 


\section{B. Supplemental Tables}




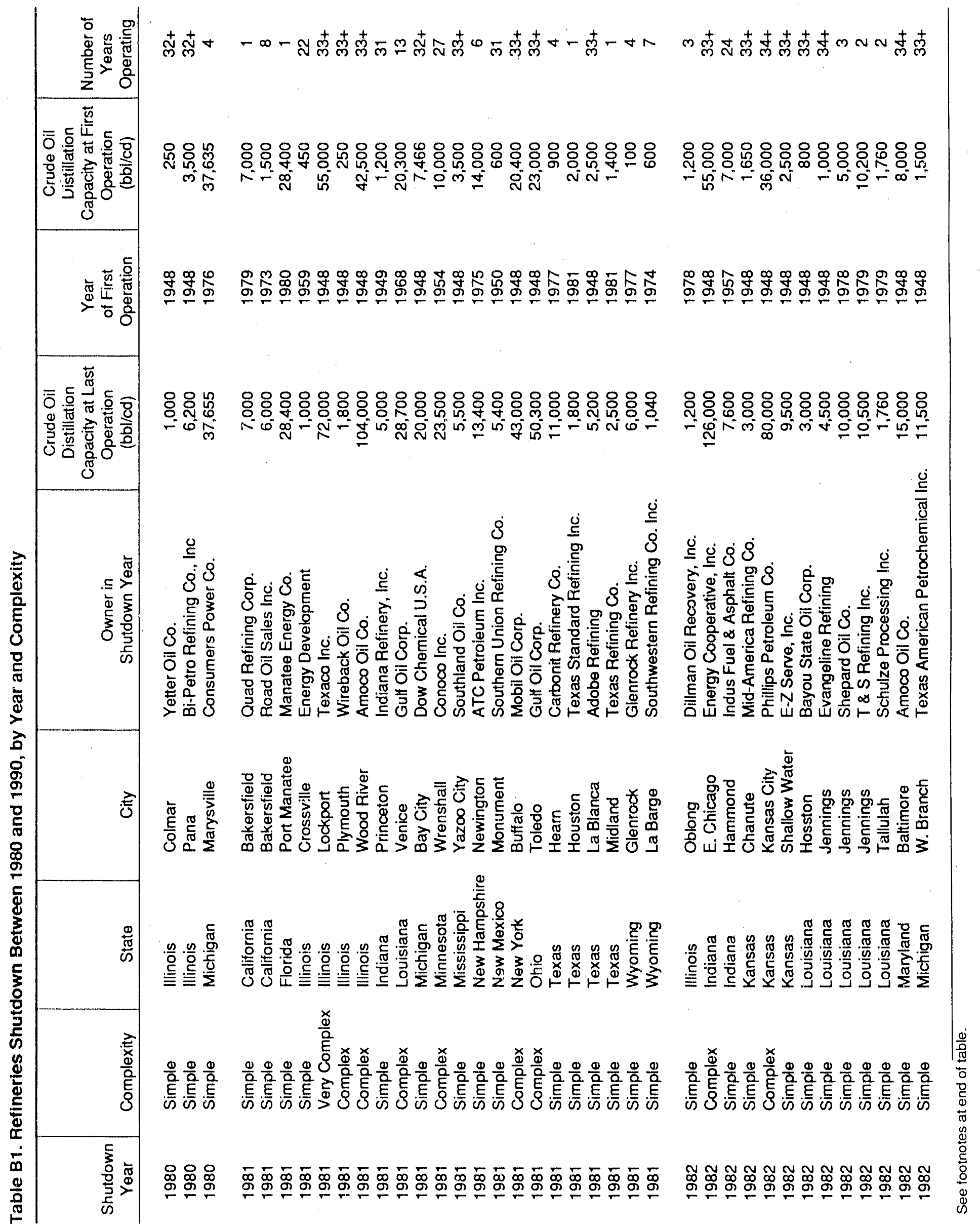




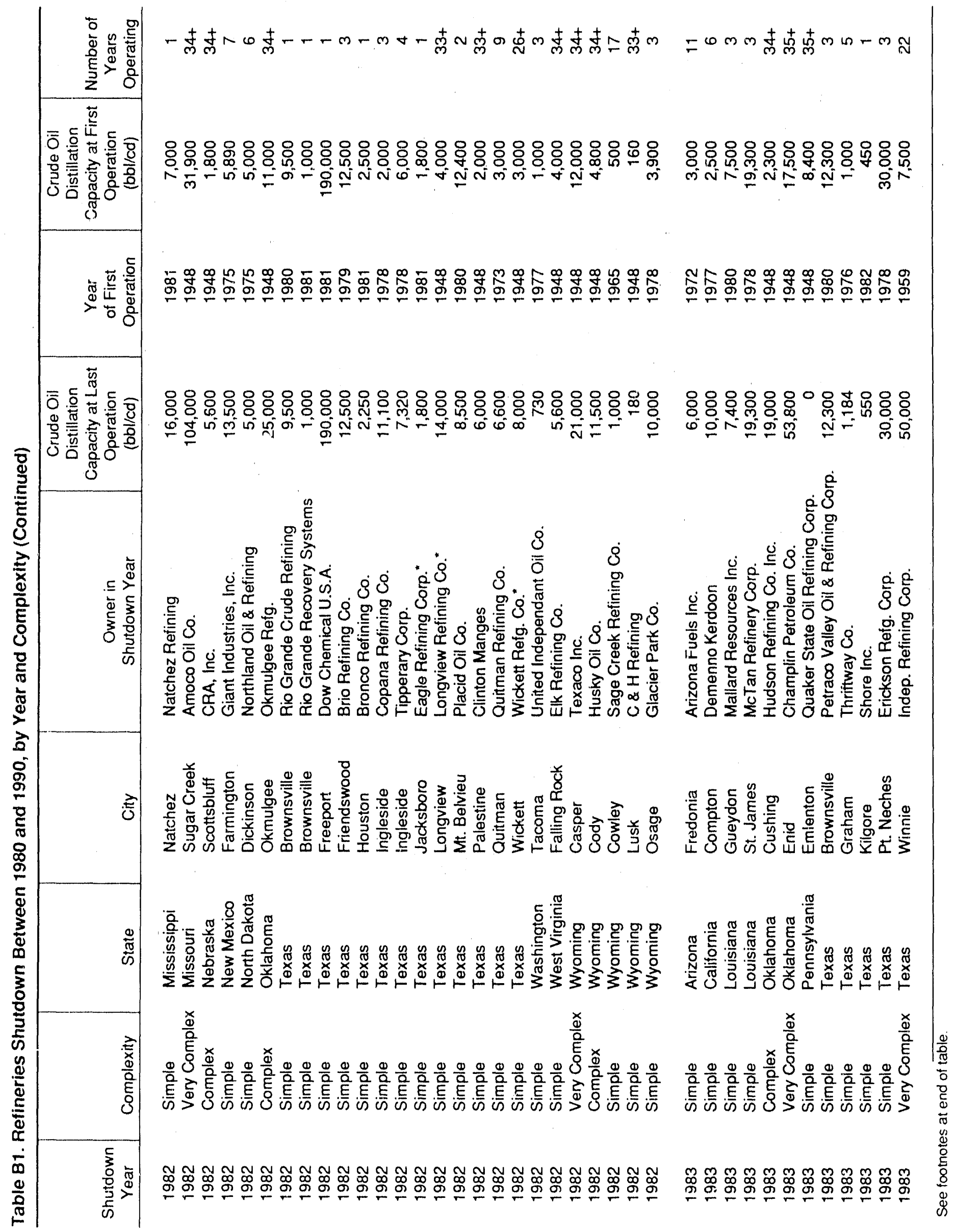




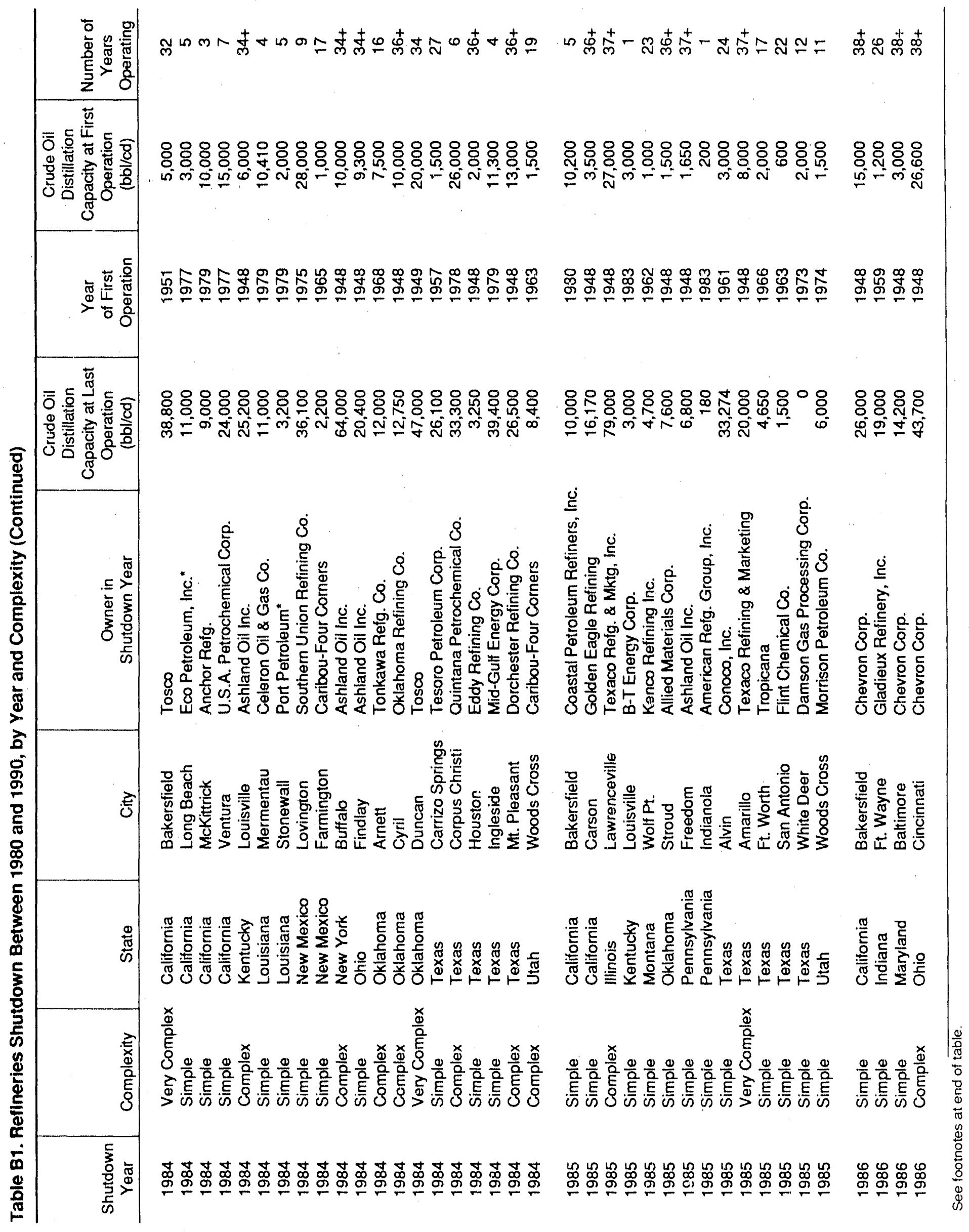




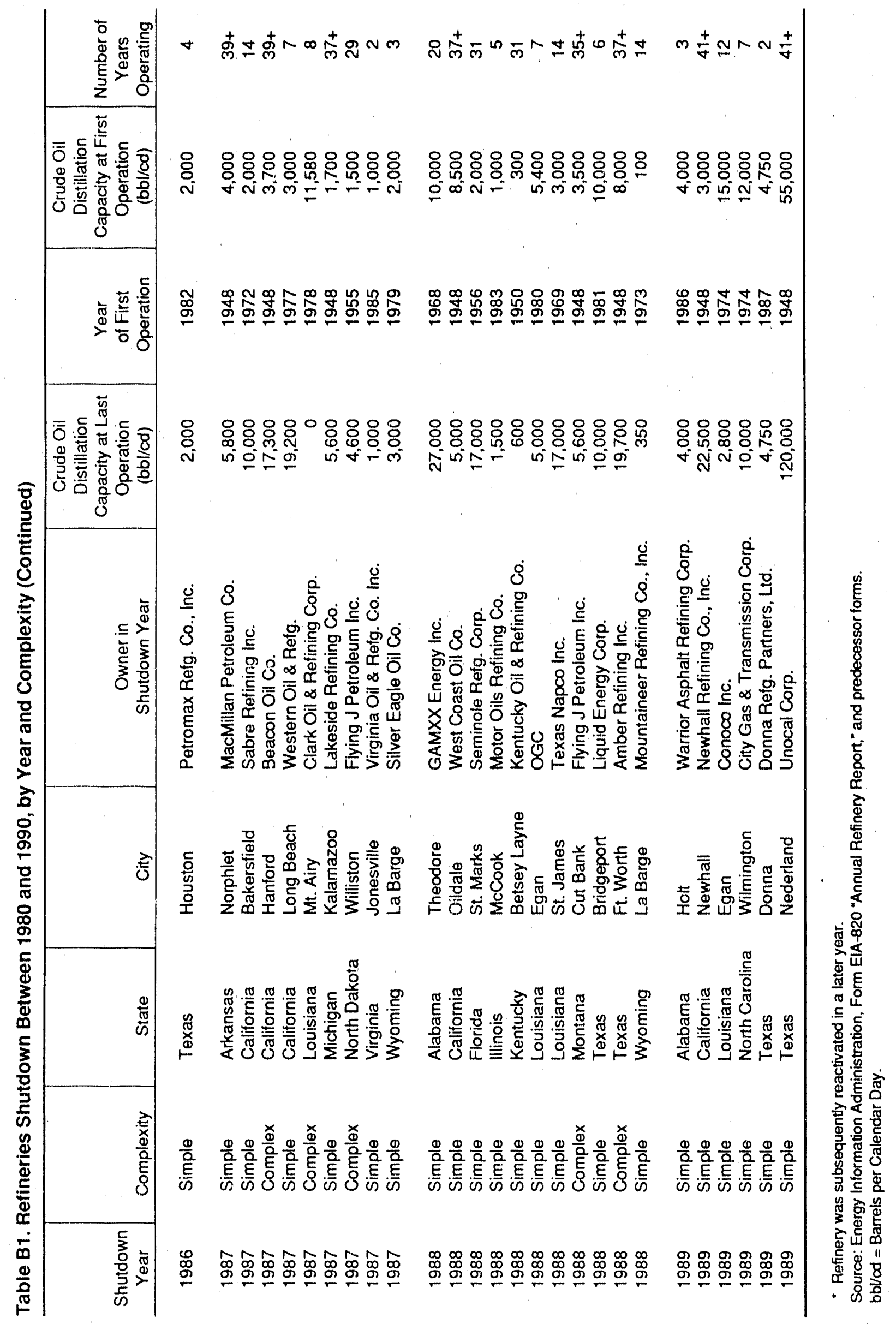


Table B2. Refinerles Permanently Shutdown Between January 1, 1980, and January 1, 1990, by PAD District*

\begin{tabular}{c|c|c|c|c|c|}
\hline & $\begin{array}{c}\text { Crude } \\
\text { Distillation } \\
\text { Capacity at Last } \\
\text { Operation } \\
\text { (bbl/cd) }\end{array}$ & $\begin{array}{c}\text { Total } \\
\text { Downstream } \\
\text { Capacity at Last } \\
\text { Operation } \\
\text { (bbl/sd) }\end{array}$ & $\begin{array}{c}\text { Date } \\
\text { of Last } \\
\text { Operation }\end{array}$ & $\begin{array}{c}\text { Date } \\
\text { Shutdown }\end{array}$ \\
\hline
\end{tabular}

PAD Distrlat I

American Refining Group Inc.

Amoco Oil Co.

Ashland Oil Inc.

Ashland Oil Inc.

ATC Petroleum Inc.

Chevron U.S.A. Inc.

City Gas \& Transmission Corp.

Elk Refining Co., div. of

Pennzoll Co. Inc.

Manateo Energy Co.

Mobil Oil Corp.

Quaker State Oil Refining Corp.

Seminole Refining Corp.

Virginia Oil and Refining Co., Inc.

\section{PAD District II}

Allied Materials Corp.

Amoco Oil Co.

Amoco Oil Co.

Ashland Oil Inc.

Ashland Oil Inc.

B-T Energy Corp.

Bi-Petro Refining Co. Inc.

Champlin Petroleum Co.

Chevron U.S.A. Inc.

Conoco Inc.

Consumers Power Co.

CRA, lnc.

Dillman Oil Recovery Inc.

Dow Chemical U.S.A.

E-Z Serv Refining Inc.

Energy Cooperative Inc.

Energy Development

Flying J. Petroleum, Inc.

Gladieux Refinery Inc.

Gulf Oil Corp.

Hudson Refining Co. Inc.

Indiana. Refining Inc.

Industrial Fuel and Asphalt of

Indiana Inc.

Kentucky Oil \& Refining

Lakeside Refining Co.

Mid-America Refining Co. Inc.

Motor Oils Refining

Northland Oil and Refining Co.

Oklahoma Refining Co.

Okmulge日 Refining Co.

Phillips Petroleum Co.

Texaco Inc.

Texaco Refining \& Marketing Inc.

Texas American Petrochemical Inc.
218,580

Indianola, PA

Baltimore, MD

Buffalo, NY

Freedom, PA

Nowington, NH

Baltimore, MD

Wilmington, NC

Falling Rock, WV

Port Manatee, FL

Buffalo, NY

Emlenton, PA

St. Marks, FL

Jonesville, VA

180

15,000

64,000

6,800

13,400

14,200

10,000

5,600

28,400

43,000

17,000

1,000
$1,055,605$

Stroud, OK

Sugar Creek, MO

Wood River, IL

Findlay, $\mathrm{OH}$

Louisville, KY

Louisville, KY

Pana, IL

Enid, OK

Cincinnati, $\mathrm{OH}$

Wrenshall, MN

Marysville, MI

Scottsbluff, NE

Oblong, IL

Bay City, MI

Shallow Water, KS

East Chicago, IN

Crossville, IL

Williston, ND

Fort Wayne, IN

Toledo, $\mathrm{OH}$

Cushing, OK

Princeton, IN

Hammond, IN

Betsey Layne, KY

Kalamazoo, MI

Chanute, KS

McCook, IL

Dickinson, ND

Cyril, OK

Okmulgee, OK

Kansas City, KS

Lockport, IL

L.awrenceville, IL

West Branch, MI
7,600

104,000

104,000

20,400

25,200

3,000

6,200

53,800

43,700

23,500

37,655

5,600

1,200

20,000

9,500

126,000

1,000

4,600

19,000

50,300

19,000

5,000

7,600

600

5,600

3,000

1,500

5,000

12,750

25,000

80,000

72,000

79,000

11,500
207,770

$\begin{array}{rr}0 & 03 / 8 \\ 0 & 01 / 8 \\ 106,500 & 07 / 8 \\ 3,600 & 04 / 85 \\ 0 & 07 / 8 \\ 14,300 & 12 / 8\end{array}$

$03 / 84$

$01 / 82$

$04 / 85$

$07 / 81$

$12 / 86$
$05 / 81$

2,000

0

67,000

2,980

11,390

0

$1,311,450$

$$
\begin{array}{r}
2,500 \\
185,500 \\
127,000 \\
8,000 \\
29,000
\end{array}
$$

$$
\begin{aligned}
& 0 \\
& 0
\end{aligned}
$$

58,500

40,200

25,700

$$
\begin{array}{r}
0 \\
3,650 \\
0
\end{array}
$$$$
\begin{aligned}
& 0 \\
& 0
\end{aligned}
$$

190,000

0
5,450

5,450

61,800

12,150

0

$12 / 82$

$05 / 81$

$05 / 81$

$12 / 83$

$05 / 87$

$08 / 87$

$12 / 85$

$03 / 82$

$12 / 84$

$12 / 85$

$12 / 81$

$12 / 86$

$12 / 89$

$12 / 82$

$10 / 81$

$07 / 81$

$12 / 83$

$03 / 88$

$12 / 87$$$
\text { to }
$$$$
\begin{aligned}
& 0 \\
& 0 \\
& 0
\end{aligned}
$$

1,800

1,200

0

23,100

13,200

156,700

136,000

134,000

3,200
$12 / 84$

$05 / 82$

$05 / 81$

$02 / 82$

$04 / 82$

$11 / 84$

$01 / 80$

$06 / 83$

$05 / 86$

$05 / 81$

$01 / 80$

$05 / 82$

$01 / 81$

$05 / 80$

$04 / 81$

$05 / 81$

$02 / 81$

$08 / 84$

$12 / 85$

$06 / 81$

$12 / 82$

$12 / 80$

$12 / 81$

$02 / 81$

$09 / 85$

$03 / 81$

$01 / 88$

$02 / 81$

$12 / 84$

$06 / 82$

$08 / 82$

$04 / 81$

$04 / 85$

$09 / 81$
$02 / 85$

$06 / 82$

$10 / 81$

$12 / 84$

$12 / 84$

$11 / 85$

$04 / 80$

$12 / 83$

$08 / 86$

$09 / 81$

$02 / 80$

$06 / 82$

$02 / 82$

$09 / 81$

$02 / 82$

$06 / 82$

$04 / 81$

$12 / 87$

$06 / 86$

$11 / 81$

$11 / 83$

$02 / 81$

$06 / 82$

$11 / 88$

$12 / 87$

$07 / 82$

$02 / 88$

$02 / 82$

$12 / 84$

$12 / 82$

$09 / 82$

$10 / 81$

$12 / 85$

$02 / 82$ 
Table B2. Reflnerles Permanently Shutdown Between January 1, 1980, and January 1, 1990, by PAD District* (Continued)

\begin{tabular}{|c|c|c|c|c|c|}
\hline District/Refinery & Location & \begin{tabular}{|c|} 
Crude \\
Distillation \\
Capacity at Last \\
Operatlon \\
(bbl/cd)
\end{tabular} & $\begin{array}{c}\text { Total } \\
\text { Downstream } \\
\text { Capacity at Last } \\
\text { Operation } \\
\text { (bbl/sd) }\end{array}$ & $\begin{array}{c}\text { Date } \\
\text { of Last } \\
\text { Operation }\end{array}$ & $\begin{array}{c}\text { Date } \\
\text { Shutdown }\end{array}$ \\
\hline
\end{tabular}

\section{PAD District II (Continued)}

Tonkawa Refining Co.

Tosco Corp.

Wireback Oil Co.

Yetter Oll Co.

\section{PAD District III}

Adobe Refining Co.

Amber Refining Inc.

Bayou State Oil Corp.

Brio Refining Inc.

Bronco Refining Co.

Carbonit Refining Co.

Caribou-Four Corners Inc.

Celeron Oll \& Gas Co.

Clark Oil and Refining Corp.

Clinton Manges

Conoco, Inc.

Conoco, Inc.

Copano Refining Co.

Damson Gas Processing Corp.

Donna Refining Partners, Ltd.

Dorchester Refining Co.

Dow Chemical U.S.A.

Eddy Refining Co.

Erickson Refining Corp.

Evangeline Refining Co.

Flint Chemical Co.

GAMXX Energy Inc.

Giant Industries inc.

Gulf Oil Corp.

Independent Refining Corp.

Liquid Energy Corp.

MacMillan Petroleum Co.

Mallard Resources Inc.

McTan Refining Corp.

Mid-Gulf Energy Corp.

Natchez Refining Co.

OGC Corp.

Petraco-Valley Oil Refining Corp.

Petromax Refining Co. Inc.

Placid Oil Co.

Quintana Petrochemical Co.

Quitman Refining Co.

Rio Grande Crude Refining

Rio Grande Recovery Systems Inc.

Schulze Processing Inc.

Shepard Oil Co.

Shore, Inc.

Southern Union Refining Co.

Southern Union Refining Co.

Southlarid Oil Co.

Tesoro Petroleum Corp.
Arnett, OK

Duncan, OK

Plymouth, IL

Colmar, IL

12,000

47,000

1,800

1,000

950,188

5,200

La Blanca, TX

Fort Worth, TX

Hosston, LA

Friendswood, TX

Houston, TX

Hearne, TX

Farmington, NM

Mermentau, LA

Mt. Airy, LA

Palestine, TX

Alvin/Texas City, TX

Egan, LA

Ingleside, TX

White Deer, TX

Donna, TX

Mt. Pleasant, TX

Freeport, TX

Houston, TX

Pt. Neches, TX

Jennings, LA

San Antonio, TX

Theodore, AL

Farmington, NM

Venice, LA

Winnie, TX

Bridgeport, TX

Norphlet, AR

Gueydan, LA

St. James, LA

Ingleside, TX

Natchez, MS

Egan, LA

Brownsville, TX

Houston, TX

Mont Belvieu, TX

Corpus Christi, TX

Quitman, TX

Brownsville, TX

Brownsville, TX

Tallulah, LA

Jennings, LA

Kilgore, TX

Monument, NM

Lovington, NM

Yazoo City, MS

Carrizo Springs, TX
19,700

3,000

12,500

2,250

11,000

2,200

11,000

0
6,000

33,274

2,800

11,100

4,750

26,500

190,000

. 3,250

30,000

4,500

1,500

27,000

13,500

28,700

50,000

10,000

5,800

7,400

19,300

39,400

16,000

5,000

12,300

2,000

8,500

33,300

6,600

9,500

1,000

1,760

10,000

550

5,400

36,100

5,500

26,100
6,000
85,000
1,800
0

$06: 94$

06/8's

$02 / 81$

$07 / 80$

563,980

$\begin{array}{rr}0 & 11 / 8 \\ 17,700 & 12 / 85 \\ 0 & 01 / 8 \\ 0 & 09 / 8 \\ 0 & 04 / 8 \\ 0 & 02 / 8 \\ 2,400 & 05 / 8 \\ 0 & 02 / 83 \\ 27,000 & 12 / 8\end{array}$

$07 / 81$

$10 / 85$

$12 / 86$

$09 / 81$

$02 / 85$

$11 / 89$

$09 / 84$

$08 / 81$

$10 / 84$

$12 / 81$

$12 / 82$

$01 / 85$

$01 / 88$

$05 / 82$

$04 / 81$

$10 / 81$

$02 / 87$

$08 / 87$

$11 / 83$

$07 / 81$

$10 / 83$

$06 / 82$

$09 / 87$

$03 / 83$

$09 / 85$

$01 / 82$

$07 / 84$

$04 / 82$

$06 / 81$

$05 / 81$

$05 / 81$

$05 / 81$

$03 / 83$

$01 / 81$

$08 / 84$

$02 / 81$

$07 / 84$
$09 / 84$

$12 / 84$

$03 / 81$

$07 / 80$

$12 / 81$

$12 / 88$

$03 / 82$

$12 / 82$

$07 / 82$

$12 / 81$

$08 / 84$

$08 / 84$

$12 / 87$

$07 / 82$

$12 / 85$

$02 / 89$

$02 / 82$

$05 / 85$

$12 / 89$

$12 / 84$

$06 / 82$

$11 / 84$

$08 / 83$

$12 / 82$

$03 / 85$

$03 / 88$

$11 / 82$

$12 / 81$

$08 / 83$

$10 / 88$

$12 / 87$

$12 / 83$

$08 / 83$

$05 / 84$

$09 / 82$

$10 / 88$

$12 / 83$

$05 / 86$

$07 / 82$

$09 / 84$

$06 / 82$

$06 / 82$

$02 / 82$

$08 / 82$

$02 / 82$

$07 / 83$

$10 / 81$

$11 / 84$

$07 / 81$

$12 / 84$

See footnotes at end of table. 
Table B2. Refineries Permanently Shutdown Between January 1, 1980, and January 1, 1990, by PAD District* (ContInued)

\begin{tabular}{c|c|c|c|c|c|c|c|}
\hline & $\begin{array}{c}\text { Crude } \\
\text { Distillation } \\
\text { Capacity at Last } \\
\text { Operation } \\
\text { (bbl/cd) }\end{array}$ & $\begin{array}{c}\text { Total } \\
\text { Capacity at Last } \\
\text { Operation } \\
\text { (bbl/sd) }\end{array}$ & $\begin{array}{c}\text { Date } \\
\text { of Last } \\
\text { Operation }\end{array}$ & $\begin{array}{c}\text { Date } \\
\text { Shutdown }\end{array}$ \\
\hline
\end{tabular}

\section{PAD Distrlct III (Cont!nisiod)}

Texaco Refg. \& Marketing Inc.

$\mathrm{T} \&$ S Refining Co.

Texas Napco Inc.

Texas Refining Co.

Texas Standard Refining Inc.

Thriftway Oll Co.

Tipperary Refining Co.

Tropicana

Unocal Corp.

Warrior Asphalt Refining Corp.

\section{PAD District IV}

Caribou-Four Corners

C \& H Refinery Inc.

Flying J. Petroleum Inc.

Glacier Park Co.

Glenrock Refinery Inc.

Husky Oil Co.

Kenco Refining Inc.

Morrison Petroleum Co.

Mountaineer Refg. Co. Inc.

Sage Creok Refining Co.

Silver Eagle Oll Co.

Southwestern Refining Co.

Texaco Inc.

\section{PAD Distrlct V}

Anchor Refining Co. Inc.

Arizona Fuels inc.

Beacon Oll Co.

Chevron U.S.A. Inc.

Coastal Petroleum Refiners, Inc.

Demenno-Kerdoon

Golden Eagle Refining Co., Inc.

Nowhall Refining Co. Inc.

Quad Refining Corp.

Road Oil Sales Inc.

Sabre Refining Inc.

Tosco Corp.

United Independent Oil Co.

U.S.A. Petrochemical Corp.

West Coast Oil Co.

Western Oll \& Refining

$\begin{array}{lr}\text { Amailllo, TX } & 20,000 \\ \text { Jennings, LA } & 10,500 \\ \text { St. James, LA } & 17,000 \\ \text { Midland, TX } & 2,500 \\ \text { Houston, TX } & 1,800 \\ \text { Graham, TX } & 1,184 \\ \text { Ingleside, TX } & 7,320 \\ \text { Fort Worth (Euless), TX } & 4,650 \\ \text { Nederland, TX } & 120,000 \\ \text { Holt, AL } & 4,000\end{array}$

78,770

Woods Cross, UT

Lusk, WY

Cutbank, MT

Osage, WY

Glenrock, WY

Cody, WY

Wolf Point, MT

Woods Cross, UT

La Barge, WY

Cowley, WY

La Barge, WY

La Barge, WY

Casper, WY

McKittrick, CA

Fredonia, AZ

Hanford, CA

Bakersfield, CA

Bakersfield, CA

Compton, CA

Carson, CA

Newhall, CA

Bakersfield, CA

Bakersfield, CA

Bakersfield, CA

Bakersfield, CA

Tacoma, WA

Ventura, CA

Oildale, CA

Long Beach, CA
8,400

180

5,600

10,000

6,000

11,500

4,700

6,000

350

1,000

3,000

1,040

21,000

227,700

9,000

6,000

17,300

26,000

10,000

10,000

16,170

22,500

7,000

6,000

10,000

38,800

730

24,000

5,000

19,200

$\begin{array}{rll}24,400 & 04 / 85 & 12 / 85 \\ 0 & 07 / 81 & 03 / 82 \\ 20,000 & 08 / 83 & 12 / 88 \\ 0 & 04 / 81 & 06 / 81 \\ 0 & 01 / 81 & 10 / 81 \\ 0 & 04 / 81 & 11 / 83 \\ 0 & 01 / 82 & 03 / 82 \\ 0 & 12 / 83 & 12 / 85 \\ 63,600 & 12 / 89 & 12 / 89 \\ 0 & 08 / 89 & 12 / 89\end{array}$

69,200

$8,200 \quad 12 / 82 \quad 12 / 84$

$01 / 81 \quad 02 / 82$

$03 / 83 \quad 02 / 88$

$02 / 81 \quad 03 / 82$

$04 / 81 \quad 09 / 81$

$06 / 82 \quad 09 / 82$

$10 / 85 \quad 12 / 85$

$12 / 85 \quad 12 / 85$

$12 / 87 \quad 06 / 88$

$01 / 82 \quad 06 / 82$

$10 / 82 \quad 12 / 87$

$04 / 81 \quad 08 / 81$

$03 / 82 \quad 07 / 82$

139,880

$\begin{array}{lll}7,000 & 11 / 82 & 02 / 84\end{array}$

$09 / 83$

$12 / 87$

$07 / 86$

$12 / 85$

$08 / 83$

$02 / 85$

$12 / 89$

$10 / 81$

$12 / 81$

$09 / 87$

$11 / 84$

$03 / 82$

$12 / 84$

$10 / 88$

$12 / 87$

U.S. Total

$2,530,843$

$2,292,280$

- Does not include refineries that were shutdown and subsequently reactivated during this period.

$\mathrm{bbl} / \mathrm{cd}=$ Barrels per Calendar Day.

$\mathrm{bbl} / \mathrm{sd}=$ Barrels per Stream Day .

Source: Energy Information Aministration, Form EIA-820, "Annual Refinery Report." 
Table B3. Refinerles Reactivated Between January 1, 1980, and January 1, 1990

\begin{tabular}{|c|c|c|c|c|c|}
\hline $\begin{array}{c}\text { Reactivation } \\
\text { Year }\end{array}$ & Complexity & State & Clty & Name & $\begin{array}{c}\text { Crude Oll } \\
\text { Distlllatlon } \\
\text { Capacity at Time } \\
\text { of Reactivation } \\
\text { (bbl/od) }\end{array}$ \\
\hline 1980 & Simple & Mississippl & Natchez & Natchez Reflning Co." & 15,000 \\
\hline 1980 & Simple & Texas & Bridgeport & Liquld Energy Corp." & 10,000 \\
\hline 1980 & Simple & Texas & Brownsville & $\begin{array}{l}\text { Val Verde Internatlonal* } \\
\text { (later known as Rlo Grando } \\
\text { Crude Refining) }\end{array}$ & 2,000 \\
\hline 1980 & Simple & Texas & Freeport & Dow Chemical U.S.A." & 190,000 \\
\hline 1980 & Simple & Texas & Houston & Bronco Refg. Co." & 2,500 \\
\hline 1980 & Simple & Texas & Houston & Texas Standard Refg., Inc." & 2,000 \\
\hline 1980 & Simple & Texas & Jacksboro & Eagle Reflning*" & 1,800 \\
\hline 1980 & Simple & Texas & Midland & Texas Refining Co." & 2,330 \\
\hline 1981 & Simple & Texas & Kllgore & Shore, Inc." & 450 \\
\hline 1982 & Simple & California & Benicla & Huntway Refining Co. & 6,750 \\
\hline 1982 & Complex & Callfornia & Paramount & $\begin{array}{l}\text { Independent Valley Energy Co. } \\
\text { (currently Paramount) }\end{array}$ & 27,000 \\
\hline 1982 & Simple & Illinois & McCook & Motor Oils Refining" & 1,000 \\
\hline 1982 & Simple & Indlana & Troy & $\begin{array}{l}\text { Kentucky Oll \& Refg. } \\
\text { (currently Inter-Coastal Energy } \\
\text { Services Corp.) }\end{array}$ & 1,000 \\
\hline 1982 & Simple & Kentucky & Louisville & B-T Energy Corp." & 3,000 \\
\hline 1982 & Simple & North Carolina & Greensboro & GNC Energy Corp. & 3,000 \\
\hline 1982 & Simple & Pennsylvania & Indlanola & American Relg. Group* & 200 \\
\hline 1982 & Simple & Texas & Houston & Petromax Refining Co. Inc." & 2,000 \\
\hline 1983 & Simple & California & Bakersfield & Coastal Petroleum Co." & 10,000 \\
\hline 1983 & Simple & California & Bakersfield & Gibson Oil \& Refining Co. & 3,000 \\
\hline 1983 & Simple & Callfornia & Olldale & West Coast Oil Co." & 19,000 \\
\hline 1983 & Complex & North Dakota & Williston & Flying J Inc." & 3,580 \\
\hline 1983 & Simple & New Mexico & Farmington & Caribou-Four Corners Inc." & 2,200 \\
\hline 1983 & Complex & Oklahoma & Tuisa & Sinclair Oll Corp. & 50,000 \\
\hline 1983 & Simple & Texas & Euless/Ft. Worth & Troplcana Energy Co." & 4,650 \\
\hline 1984 & Complex & New Jersey & Port Reading & Amerada Hess Corp. & 68,000 \\
\hline 1985 & Simple & California & Bakersfield & Sabre Refining Inc." & 10,000 \\
\hline 1985 & Simple & Florida & St. Marks & Seminole Refining Corp." & 17,000 \\
\hline 1985 & Complex & Loulsiana & Krotz Springs & Hill Petroleum Co. & 56,300 \\
\hline 1985 & Simple & Oklahoma & Thomas & Barrett Refining Corp. & 9,300 \\
\hline 1985 & Simple & Texas & Nixon & Leal Petroleum Corp. & 16,397 \\
\hline 1985 & Simple & Texas & Silsbee & South Hampton Reig. Co. & 20,250 \\
\hline 1985 & Simple & Wyoming & LaBarge & Silver Eagle Oil Co." & 2,500 \\
\hline 1986 & Simple & Alabama & Holt & Warrior Asphalt Refining Corp." & 5,000 \\
\hline 1986 & Simple & Californla & Long Beach & Western Oil \& Refining Inc." & 19,200 \\
\hline 1986 & Very Complex & Callfornia & Santa $\mathrm{Fe}$ Springs & Powerine Oll Co. & 33,400 \\
\hline 1986 & Simple & Kansas & Augusta & $\begin{array}{l}\text { Augusla Refinery } \\
\text { (currently Coastal Derby Refg.) }\end{array}$ & 0 \\
\hline 1986 & Simple & Louislana & St. Rose & Hill Petroleum Co. & 32,000 \\
\hline 1986 & Simple & North Carolina & Wilmington & City Gas \& Transmission Corp." & 10,000 \\
\hline 1987 & Simple & Alabama & Theodore & GAMXX Energy Inc." & 27,000 \\
\hline 1987 & Very Complex & Louisiana & Norco & Trans America Refg. Co. & 300,000 \\
\hline 1987 & Simple & Mississippi & Vicksburg & Petro Source Resources, Inc. & 6,000 \\
\hline 1987 & Simple & Texas & Donna & Donna Refining Partners, Ltd." & 4,750 \\
\hline
\end{tabular}


Table B3. Refinerles Reactlvated Between January 1, 1980, and January 1, 1990 (ContInued)

\begin{tabular}{|c|c|c|c|c|c|}
\hline $\begin{array}{c}\text { Reaotivation } \\
\text { Year }\end{array}$ & Complexity & State & Clty & Name & $\begin{array}{c}\text { Crude Oाl } \\
\text { Dlstillatlon } \\
\begin{array}{c}\text { Capaolty at Time } \\
\text { of Reactivatlon } \\
\text { (bbl/cd) }\end{array} \\
\end{array}$ \\
\hline $\begin{array}{l}1988 \\
1988\end{array}$ & $\begin{array}{l}\text { Very Complex } \\
\text { Simple }\end{array}$ & $\begin{array}{l}\text { Colorado } \\
\text { Louisiana }\end{array}$ & $\begin{array}{l}\text { Fruita } \\
\text { Lake Charles }\end{array}$ & $\begin{array}{l}\text { Western Slope Refg. Co. } \\
\text { American International Refg., Ino. }\end{array}$ & $\begin{array}{l}15,200 \\
27,000\end{array}$ \\
\hline $\begin{array}{l}1989 \\
1989 \\
1989 \\
1989 \\
1989\end{array}$ & $\begin{array}{l}\text { Simple } \\
\text { Simple } \\
\text { Simple } \\
\text { Simple } \\
\text { Simple }\end{array}$ & $\begin{array}{l}\text { Californla } \\
\text { Louislana } \\
\text { Texas } \\
\text { Texas } \\
\text { Texas }\end{array}$ & $\begin{array}{l}\text { Long Beach } \\
\text { Stonewall } \\
\text { Jacksboro } \\
\text { Longview } \\
\text { Wickett }\end{array}$ & $\begin{array}{l}\text { Eco Asphalt, Inc. } \\
\text { Sabine Resources Group } \\
\text { Eagle Refining Corp. } \\
\text { Longvlew Reflining Assoc. } \\
\text { Rattlesnake Refg. Corp. }\end{array}$ & $\begin{array}{r}10,550 \\
10,000 \\
1,800 \\
13,300 \\
8,000\end{array}$ \\
\hline
\end{tabular}

* Refinery was shutdown in 1982 and reopened again in 1989.

- Refinery was subsequently permanently shutdown.

$\mathrm{bbl} / \mathrm{cd}=$ Barrels per Calendar Day.

Source: Energy Information Administration, Form ElA-820, "Annual Refining Report," and predecessor forms. 


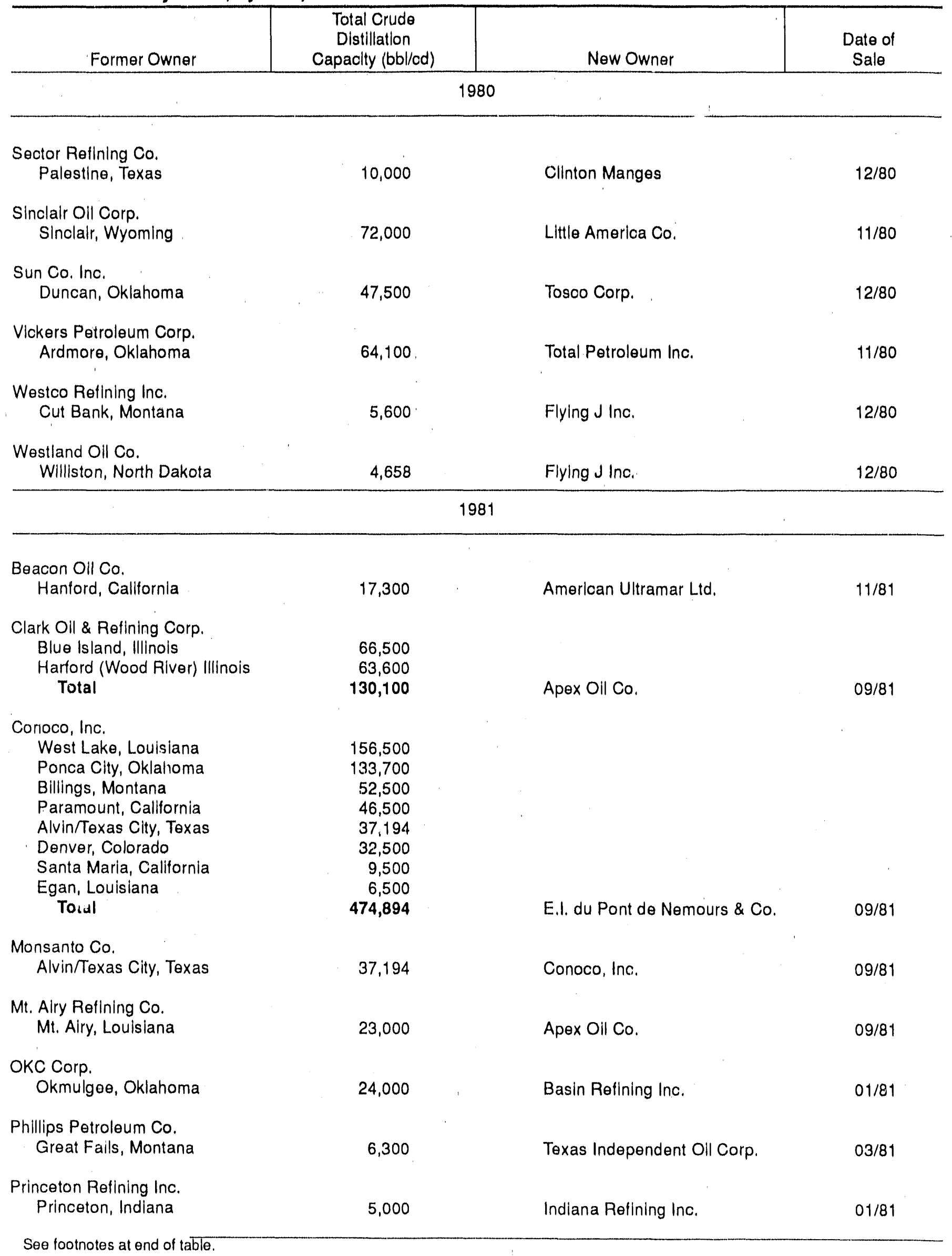




\begin{tabular}{|c|c|c|c|}
\hline Former Owner & $\begin{array}{c}\text { Total Crude } \\
\text { Distillatlon } \\
\text { Capacity (bbl/cd) }\end{array}$ & New Owner & $\begin{array}{l}\text { Date of } \\
\text { Sale }\end{array}$ \\
\hline \multicolumn{4}{|c|}{1981 (contlnued) } \\
\hline $\begin{array}{l}\text { Sun Co. Inc. } \\
\text { Corpus Christl, Texas }\end{array}$ & 57,000 & Koch Industries, Inc. & $11 / 81$ \\
\hline $\begin{array}{l}\text { Uni Refining Co. } \\
\text { Ingleside, Texas }\end{array}$ & 30,000 & Texas Independent Oil Corp. & $03 / 81$ \\
\hline $\begin{array}{l}\text { United Refining Co. } \\
\text { Warren, Pennsylvania }\end{array}$ & 60,000 & Coral Petroleum & $03 / 81$ \\
\hline $\begin{array}{l}\text { Winston Refining Co. } \\
\text { Fort Worth, Texas }\end{array}$ & 20,000 & E-Z Serv & $02 / 81$ \\
\hline \multicolumn{4}{|c|}{1982} \\
\hline $\begin{array}{c}\text { Earth Resources Co. } \\
\text { Memphis, Tennessee } \\
\text { North Pole, Alaska } \\
\text { Total }\end{array}$ & $\begin{array}{l}49,500 \\
45,323 \\
94,823\end{array}$ & Mid-America Pipeline System & $05 / 82$ \\
\hline $\begin{array}{l}\text { Marathon Oll Co. } \\
\text { Garyville, Loulsiana } \\
\text { Robinson, Illinols } \\
\text { Texas City, Texas } \\
\text { Detroit, Michigan } \\
\text { Total }\end{array}$ & $\begin{array}{r}255,000 \\
195,000 \\
69,500 \\
68,500 \\
588,000\end{array}$ & U.S. Steol & $01 / 82$ \\
\hline $\begin{array}{l}\text { Shell Oll Co. } \\
\text { Gallup, New Mexico }\end{array}$ & 18,000 & Giant Industries Inc. & $.04 / 82$ \\
\hline $\begin{array}{l}\text { Sound Refining Inc. } \\
\text { Tacoma, Washington }\end{array}$ & 6,000 & Crysen Corp. & $01 / 82$ \\
\hline $\begin{array}{l}\text { Western Refining Co. } \\
\text { Woods Cross, Utah }\end{array}$ & 12,500 & Crysen Corp. & $06 / 82$ \\
\hline \multicolumn{4}{|c|}{1983} \\
\hline $\begin{array}{l}\text { Celeron Oll \& Gas Co. } \\
\text { Mermentau, Louisiana }\end{array}$ & 11,000 & Goodyear Tire \& Rubber Co. & $06 / 83$ \\
\hline $\begin{array}{l}\text { Citles Service Co. } \\
\text { Lake Charles, Loulsiana }\end{array}$ & 320,000 & Occidental Petroleum & $01 / 83$ \\
\hline $\begin{array}{l}\text { Occidental Petroleum } \\
\text { Lake Charles, Louisiana }\end{array}$ & 320,000 & Southland Corp. & $09 / 83$ \\
\hline $\begin{array}{l}\text { Gulf Oll Corp. } \\
\text { Santa } \mathrm{Fe} \text { Springs, Clalfornia }\end{array}$ & 51,500 & Thrifty Oil Co. & $08 / 83$ \\
\hline $\begin{array}{l}\text { Gulf States Oil \& Refining Co. } \\
\text { Corpus Christi, Texas }\end{array}$ & 38,000 & Koch Industries, Inc. & $01 / 83$ \\
\hline
\end{tabular}


Table B4. Refinery Sales, by Year, 1980-1989 (Continued)

\begin{tabular}{|c|c|c|c|}
\hline Former Owner & $\begin{array}{c}\text { Total Crude } \\
\text { Distillatlon } \\
\text { Capacity (bbl/cd) }\end{array}$ & New Owner & $\begin{array}{l}\text { Date of } \\
\text { Sale }\end{array}$ \\
\hline \multicolumn{4}{|c|}{1983 (continued) } \\
\hline $\begin{array}{l}\text { E.I. du Pont de Nemours \& Co. } \\
\text { Paramount, California }\end{array}$ & 46,500 & Pacific-Oasis & $01 / 83$ \\
\hline $\begin{array}{l}\text { Sigmor Corp. } \\
\text { Three Rlvers, Texas }\end{array}$ & 40,000 & Dlamond Shamrock Corp. & $01 / 83$ \\
\hline $\begin{array}{l}\text { TARCO } \\
\text { Euless, Texas }\end{array}$ & 4,650 & Tropicana Energy Co. & $12 / 83$ \\
\hline $\begin{array}{l}\text { Texaco, Inc. } \\
\text { Sinclalr, Wyoming }\end{array}$ & 50,000 & Sinclair Oll Corp. & $11 / 83$ \\
\hline $\begin{array}{c}\text { Tonkawa Reflning Co. } \\
\text { Arnett, Oklahoma } \\
\end{array}$ & 12,000 & Ray Bell Oll Co. & $06 / 83$ \\
\hline \multicolumn{4}{|c|}{1984} \\
\hline $\begin{array}{l}\text { CPI Oll \& Refining Corp. } \\
\text { Lake Charles, Loulsiana }\end{array}$ & 13,500 & Calcasieu Refining Co. & $11 / 84$ \\
\hline $\begin{array}{l}\text { Dorchester Refining Corp. } \\
\text { Mt. Pleasant, Texas } \\
\text { White Deer, Texas } \\
\text { Total }\end{array}$ & $\begin{array}{r}26,500 \\
0 \\
26,500\end{array}$ & Damson Gas Processing Corp. & $12 / 84$ \\
\hline $\begin{array}{l}\text { Edgington Oil Co. Inc. } \\
\text { Long Beach, Califo"nia }\end{array}$ & 41,600 & Triad Terminal Corp. & $12 / 84$ \\
\hline $\begin{array}{l}\text { Getty Refining \& Marketing Co. } \\
\text { Delaware City, Delaware } \\
\text { El Dorado, Kansas } \\
\text { Bakersfield, California } \\
\text { Total }\end{array}$ & $\begin{array}{r}140,000 \\
80,577 \\
48,400 \\
268,977\end{array}$ & Texaco inc. & $12 / 84$ \\
\hline $\begin{array}{l}\text { Hermes Products Co. } \\
\text { Newcastle, Wyoming }\end{array}$ & 12,555 & Wyoming Reilining Co. & $12 / 84$ \\
\hline $\begin{array}{l}\text { Husky Oil Co. } \\
\text { Cheyenne, Wyoming } \\
\text { North Salt Lake, Utah } \\
\text { Tolal }\end{array}$ & $\begin{array}{l}28,800 \\
25,000 \\
53,800\end{array}$ & RMT Properties, Inc. & $12 / 84$ \\
\hline $\begin{array}{c}\text { Indeperident Valley Energy Co. } \\
\text { Bakersfield, California }\end{array}$ & 27,000 & Paramount Petroleum Corp. & $04 / 84$ \\
\hline $\begin{array}{l}\text { Pacific-Oasis Corp. } \\
\text { Paramount, California }\end{array}$ & 46,500 & Paramount Petroleum Corp. & $04 / 84$ \\
\hline $\begin{array}{l}\text { Plateau Inc. } \\
\text { Bloomfield, New Mexico }\end{array}$ & 16,800 & Gary Energy Corp. & $12 / 84$ \\
\hline $\begin{array}{l}\text { Plateau Inc. } \\
\text { Roosevelt, Utah }\end{array}$ & 7,500 & Seagull Refining Co. & $04 / 84$ \\
\hline $\begin{array}{c}\text { Quintana Petrochemical Co. } \\
\text { Corpus Christi, Texas }\end{array}$ & 33,300 & Coastal States Petroleum Co. & $09 / 84$ \\
\hline
\end{tabular}

See footnotes at end of table. 
Table B4. Refinery Sales, by Year, 1980-1989 (Continued)

\begin{tabular}{|c|c|c|c|}
\hline Former Owner & $\begin{array}{c}\text { Total Crude } \\
\text { Distillation } \\
\text { Capacity (bbl/cd) }\end{array}$ & New Owner & $\begin{array}{c}\text { Date of } \\
\text { Sale }\end{array}$ \\
\hline \multicolumn{4}{|c|}{1985} \\
\hline $\begin{array}{l}\text { Atlantic Richfield Co. } \\
\text { Philadelplhia, Pennsylvania }\end{array}$ & 125,000 & Atlantic Petroleum Corp. & $10 / 85$ \\
\hline $\begin{array}{l}\text { Gulf Oil Corp. } \\
\text { Belle Chasse, Louisiana }\end{array}$ & 198,000 & Standard Oil Co. & $02 / 85$ \\
\hline $\begin{array}{l}\text { Gulf Oil Corp. } \\
\text { Cincinnati, Ohic } \\
\text { Philadelphia, Pennsylvania } \\
\text { Port Arthur, Texas } \\
\text { Cayamon, Puerto Rico } \\
\text { Total }\end{array}$ & $\begin{array}{r}43,700 \\
174,100 \\
406,900 \\
38,000 \\
662,700\end{array}$ & Chevron Corp. & $07 / 85$ \\
\hline $\begin{array}{l}\text { Marlex Oil \& Refining Co. } \\
\text { Los Angeles. California }\end{array}$ & 19,200 & Western Oil Refining Inc. & $08 / 85$ \\
\hline $\begin{array}{l}\text { Pride Refining Inc. } \\
\text { Abilene, Texas }\end{array}$ & 42,750 & Soberbio & $10 / 85$ \\
\hline $\begin{array}{l}\text { Saber Refining Co. } \\
\text { Corpus Christi, Texas }\end{array}$ & 18,000 & Valero Energy Corp. & $05 / 85$ \\
\hline $\begin{array}{l}\text { Seminole Refining Inc. } \\
\text { St. Marks, Florida }\end{array}$ & 17,000 & Young Refining Corp. & $05 / 85$ \\
\hline $\begin{array}{l}\text { Sentry Refining Inc. } \\
\text { Corpus Christi, Texas }\end{array}$ & 15,000 & Trifinery & $08 / 85$ \\
\hline $\begin{array}{l}\text { Texaco, Inc. } \\
\text { Westville, New Jersey }\end{array}$ & 90,000 & Coastal Eagle Point Oil Co. & $06 / 85$ \\
\hline $\begin{array}{l}\text { Tosco Corp. } \\
\text { Ei Dorado, Arkansas }\end{array}$ & 48,000 & Lion Oil Co. & $05 / 85$ \\
\hline
\end{tabular}

1986

$\begin{array}{llll}\begin{array}{l}\text { ATC Petrole. } m \text { Inc. } \\ \text { Wilmington, North Carolina }\end{array} & 10,000 & \text { City Gas \& Transmission Corp. } & \text { 02/86 } \\ \begin{array}{l}\text { Charter International Oil Co. } \\ \text { Houston, Texas }\end{array} & \text { Hill Petroleum Co. } & 03 / 86 \\ \begin{array}{c}\text { Crystal Oil Co. } \\ \text { Stephens, Arkansas }\end{array} & 65,000 & \text { Martin Gas Sales Inc. } & 01 / 86 \\ \begin{array}{l}\text { Goldking Refining Ltd. } \\ \text { Krotz Springs, Louisiana }\end{array} & 3,200 & \text { Phibro Distributing Corp. } & 01 / 86 \\ \begin{array}{l}\text { International Piocessors } \\ \text { St. Rose, Louisiana }\end{array} & 55,300 & \text { Hill Petroleum Co. } & 06 / 86 \\ \begin{array}{l}\text { Laketon Refining Corp. } \\ \text { Laketon, Indiaria }\end{array} & 32,000 & & 01 / 86\end{array}$

See íootnotes at enci oi tabie. 


\begin{tabular}{|c|c|c|c|}
\hline Former Owner & $\begin{array}{c}\text { Total Crude } \\
\text { Distillation } \\
\text { Capacity (bbl/cd) }\end{array}$ & New Owner & $\begin{array}{c}\text { Date of } \\
\text { Sale }\end{array}$ \\
\hline \multicolumn{4}{|c|}{1986 (continued) } \\
\hline $\begin{array}{c}\text { Linmar Vt/Theo Davies } \\
\text { Seagull Refining Co. } \\
\text { Roosevelt, Utah }\end{array}$ & 8,000 & Pennzoil Co. Inc. & $12 / 86$ \\
\hline $\begin{array}{l}\text { Mobil Oil Corp. } \\
\text { Augusta, Kansas }\end{array}$ & 0 & Williams Pipeline Co. & $05 / 86$ \\
\hline $\begin{array}{r}\text { Mobile Bay Refining Co. } \\
\text { Chickasaw, Alabama }\end{array}$ & 26,600 & Beicher Oil Co. & $09 / 86$ \\
\hline $\begin{array}{l}\text { Montana Refining Co. } \\
\text { Great Falls, Montana }\end{array}$ & 6,300 & Holly Corp. & $01 / 86$ \\
\hline $\begin{array}{l}\text { Oklahoma Refining Co. } \\
\text { Thomas, Oklahoma }\end{array}$ & 9,300 & Barrett Refining Corp. & $01 / 86$ \\
\hline $\begin{array}{l}\text { Pester Refining Co. } \\
\text { El Dorado, Kansas }\end{array}$ & 30,400 & Derby Refining Co. & $04 / 86$ \\
\hline $\begin{array}{l}\text { Pioneer Refining Ltd. } \\
\text { Nixon, Texas }\end{array}$ & 16,397 & Leal Petroleum Corp. & $01 / 86$ \\
\hline $\begin{array}{l}\text { Powerine Oil Co. } \\
\text { Santa Fe Springs, California }\end{array}$ & 33,400 & Sargent Holdings, Ltd. & $09 / 86$ \\
\hline $\begin{array}{l}\text { RMT Properties, Inc. } \\
\text { North Salt Lake, Utah }\end{array}$ & 24,000 & Flying J. Petroloum Inc. & $01 / 86$ \\
\hline Chey'enne, Wyoming & 28,800 & Frontier Refining Co. & $01 / 86$ \\
\hline 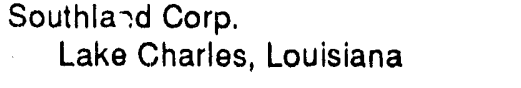 & 320,000 & Petroleos De Venezuela (50\%) & $10 / 86$ \\
\hline $\begin{array}{l}\text { Texaco Inc. } \\
\text { El Paso, Texas }\end{array}$ & 21,600 & El Paso Refining Co. Ltd. & $05 / 86$ \\
\hline $\begin{array}{l}\text { Tosco Corp. } \\
\text { Bakiersfield, California }\end{array}$ & 38,800 & Texaco Inc. & $06 / 86$ \\
\hline $\begin{array}{l}\text { Warrior Asphalt Co. of Alabama Inc. } \\
\text { Holt, Alabama }\end{array}$ & 5,000 & Warrior Asphalt Refining Corp. & $10 / 86$ \\
\hline & & & \\
\hline $\begin{array}{l}\text { Asamera Oil (US) Inc. } \\
\text { Colorado Refining Co. } \\
\text { Commerce City, Colorado }\end{array}$ & 33,500 & Total Petroleum North America, Ltd. & $06 / 87$ \\
\hline $\begin{array}{l}\text { Champlin Petroleum Co. } \\
\text { Corpus Christi, Texas }\end{array}$ & 155,200 & $\begin{array}{l}\text { Union Pacific Corp. (50\%) } \\
\text { Petroleos De Venezuela (50\%) }\end{array}$ & $04 / 87$ \\
\hline $\begin{array}{l}\text { Chevron Corp. } \\
\text { Caribbean Gulf Refining Corp. } \\
\text { San Juan, Puerto Rico }\end{array}$ & 36,000 & First Oil International Ltd. & $08 / 87$ \\
\hline
\end{tabular}




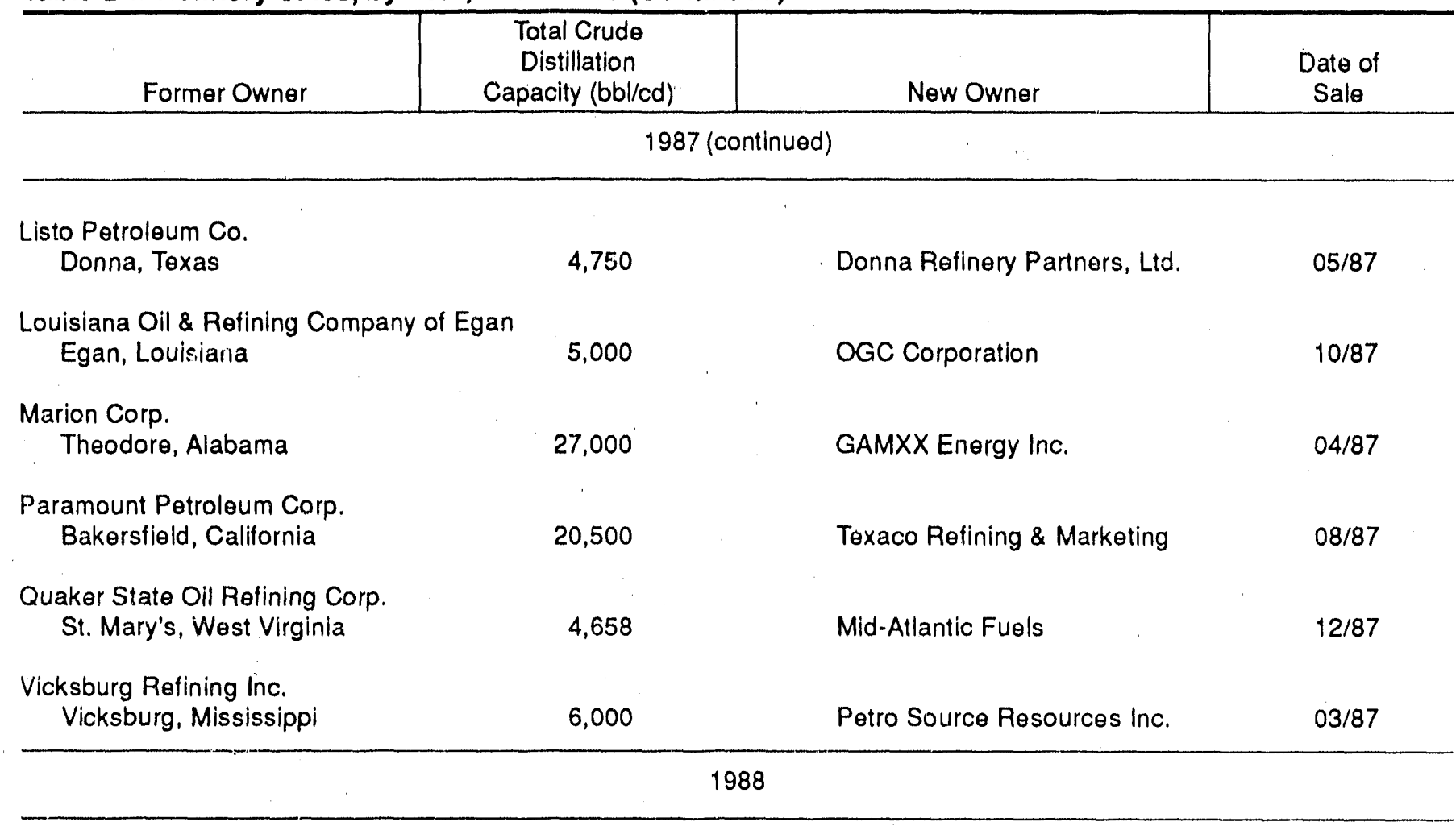

Agway Petroleum Corp.

Texas City Refg. Inc.

Texas City, Texas

Apex Oil Co.

Clark Oil \& Reig. Corp.

Blue Island, Illinois

Hartford, Illinois

Total

119,600

64,600

63,600

128,200

27,000

55,000

60,000

United Refg. Inc.

$09 / 88$

Edgington Oil Co. Inc. Long Beach, California

41,600

Sulfur Mountain Corp.

$06 / 88$

Fletcher Oil \& Refg. Co.

Carson, California

29,500

Pauley Petroleum Inc.

$03 / 88$

Guam Oil \& Refg. Co., Inc.

Agana, Guam

43,900

Shell Oil Corp.

$11 / 88$

Kerr-McGee

Dubach, Louisiana

10,000

Solomon, Inc.

Hill Petroleum Co.

$08 / 88$

$11 / 88$

$07 / 88$

$12 / 88$

Coastal Corp.
Sinochem $(50 \%)$

Soe footnotes at end of table. 


\section{Data Used to Generate Graphs}


Table C1. Average Refinery Input Composition, 1980-1989

(Thousand Barrels per Day)

\begin{tabular}{c|c|c|c|c}
\hline Year & $\begin{array}{c}\text { Crude } \\
\text { Oll }\end{array}$ & LPG & Other & Total \\
\hline \multicolumn{5}{|c}{} \\
1980 & 13,481 & 233 & 311 & 14,025 \\
1981 & 12,470 & 289 & 723 & 13,482 \\
1982 & 11,774 & 300 & 787 & 12,861 \\
1983 & 11,685 & 253 & 712 & 12,650 \\
1984 & 12,044 & 291 & 791 & 13,126 \\
1985 & 12,002 & 304 & 886 & 13,192 \\
1986 & 12,716 & 302 & 888 & 13,906 \\
1987 & 12,854 & 304 & 829 & 13,987 \\
1988 & 13,246 & 321 & 799 & 14,367 \\
1989 & 13,401 & 315 & 797 & 14,513 \\
\hline
\end{tabular}

Source: Energy Information Administration, Petroleum Supply Annual, 1989, Volume 1.
Table C3. Average API Gravity of Crude OII Inputs to Refinerles, 1981-1989 (Degrees)

\begin{tabular}{c|c}
\hline Year & $\begin{array}{c}\text { API } \\
\text { Gravity }\end{array}$ \\
\hline 1981 & \\
1982 & 33.75 \\
1983 & 33.11 \\
1984 & 33.18 \\
1985 & 32.96 \\
1986 & 32.46 \\
1987 & 32.33 \\
1988 & 32.22 \\
1989 & 31.93 \\
\hline
\end{tabular}

Sources: Energy Information Administration, Petroleum Supply Annual, Volume 2, 1981-1984; Petroleum Supply Annual, Volume 1, 1985-1989.
Table C2. Average Sulfur Content of Crude Oll Inputs to Refineries, 1981-1989

\begin{tabular}{c|c}
\hline Year & $\begin{array}{c}\text { Percent } \\
\text { Sulfur }\end{array}$ \\
\hline & \\
1981 & 0.88 \\
1982 & 0.91 \\
1983 & 0.90 \\
1984 & 0.94 \\
1985 & 0.91 \\
1986 & 0.96 \\
1987 & 0.99 \\
1988 & 1.04 \\
1989 & 1.06 \\
\hline
\end{tabular}

Sources: Energy Information Administration, Petroleum Supply Annual, Volume 1, 1985-1989; Petroleum Supply Annual, Volume 2, 1981-1984.
Table C4. Average Operable Refinery Utilization Rate, 1980-1989

\begin{tabular}{c|c}
\hline & \\
Year & Percent \\
\hline & \\
1980 & 75.4 \\
1981 & 68.5 \\
1982 & 69.8 \\
1983 & 71.7 \\
1984 & 76.2 \\
1985 & 77.6 \\
1986 & 82.9 \\
1987 & 83.1 \\
1988 & 84.4 \\
1989 & 86.3 \\
\hline
\end{tabular}

Sources: Energy Information Administration, Annual Energy Review 1988; Petroleum Supply Annual 1988 and 1989. 
Table C5. Refinery Yields of Major Petroleum Products,1980-1989

(Percent)

\begin{tabular}{|c|c|c|c|c|c|c|}
\hline Year & LPG & $\begin{array}{c}\text { Kerosene- } \\
\text { Type } \\
\text { Jet Fuel }\end{array}$ & $\begin{array}{l}\text { Residual } \\
\text { Fuel Oil }\end{array}$ & $\begin{array}{l}\text { Leaded } \\
\text { Motor } \\
\text { Gasoline }\end{array}$ & $\begin{array}{l}\text { Distillate } \\
\text { Fuel Oil }\end{array}$ & $\begin{array}{l}\text { Unleaded } \\
\text { Motor } \\
\text { Gasoline }\end{array}$ \\
\hline 1980 & 2.4 & 6.0 & 11.7 & 23.5 & 19.7 & 21.0 \\
\hline 1981 & 2.5 & 6.1 & 10.4 & 22.3 & 20.5 & 22.2 \\
\hline 1982 & 2.2 & 6.4 & 8.8 & 21.8 & 21.5 & 24.3 \\
\hline 1983 & 2.7 & 6.8 & 7.1 & 21.2 & 20.5 & 26.2 \\
\hline 1984 & 2.9 & 7.4 & 7.1 & 18.5 & 21.5 & 28.0 \\
\hline 1985 & 3.1 & 7.9 & 7.1 & 16.2 & 21.6 & 29.4 \\
\hline 1986 & 3.2 & 8.3 & 6.7 & 14.2 & 21.2 & 31.5 \\
\hline 1987 & 3.4 & 8.5 & 6.6 & 11.3 & 20.5 & 35.1 \\
\hline 1988 & 3.6 & 8.5 & 6.7 & 8.6 & 20.8 & 37.4 \\
\hline 1989 & 4.0 & 8.6 & 6.9 & 5.0 & 20.8 & 40.7 \\
\hline
\end{tabular}

Sources: Energy Information Administration, Petroleum Supply Annual 1981-1989; Energy Data Reports, "Crude Petroleum, Petroleum Products, and Natural Gas Liquids: 1980."

Table C6. Motor Gasoline Ylelds, 1980-1989

(Percent)

\begin{tabular}{l|c|c}
\hline & & \\
Year & Leaded & Unleaded \\
\hline & & \\
1980 & 23.5 & 21.0 \\
1981 & 22.3 & 22.2 \\
1982 & 21.8 & 24.3 \\
1983 & 21.2 & 26.2 \\
1984 & 18.5 & 28.0 \\
1985 & 16.2 & 29.4 \\
1986 & 14.2 & 31.5 \\
1987 & 11.3 & 35.1 \\
1988 & 8.6 & 37.4 \\
1989 & 5.0 & 40.7 \\
\hline
\end{tabular}

Sources: Energy Information Administration, Petroleum Supply Annual 1981-1989; Energy Data Reports, "Crude Petroleum, Petroleum Products, and Natural Gas Liquids: 1980." 
Table C7. Refinery Stocks of Crude Oll, 1980-1989

\begin{tabular}{|c|c|}
\hline Year & Million Barrels \\
\hline $\begin{array}{l}1980 \\
1981 \\
1982 \\
1983 \ldots \ldots \ldots \ldots . \ldots . \ldots \\
1984 \\
1985\end{array}$ & $\begin{array}{r}123,620 \\
106,879 \\
99,645 \\
103,250 \\
97,304 \\
90,192 \\
92,954 \\
95,851 \\
92,129 \\
99,711\end{array}$ \\
\hline
\end{tabular}

Note: Stock levels are as of December 31.

Sources: Energy information Administration, Petroleum Supply Annual, Volume 1, 1981-1989.; Energy Data Reports, Crude Petroleum, Petroleum Products, and Natural Gas Liquids: 1980" Table 18, p. 24.
Table C9. Petroleum Fuel Use at Refineries, 1980-1989 (Thousand Barrels per Day)

\begin{tabular}{c|c|r|r|r}
\hline Year & $\begin{array}{c}\text { Still Gas } \\
\text { \& LPG }\end{array}$ & $\begin{array}{c}\text { Catalyst } \\
\text { Coke }\end{array}$ & Other & Total \\
\hline & & & & \\
$1980 \ldots \ldots .$. & 652 & 169 & 152 & 973 \\
$1981 \ldots \ldots \ldots$. & 508 & 152 & 92 & 751 \\
$1982 \ldots \ldots \ldots$. & 524 & 167 & 77 & 768 \\
$1983 \ldots \ldots \ldots$. & 534 & 177 & 66 & 776 \\
$1984 \ldots \ldots \ldots$. & 548 & 179 & 65 & 793 \\
$1985 \ldots \ldots \ldots$. & 605 & 187 & 58 & 850 \\
$1986 \ldots \ldots \ldots$. & 661 & 203 & 55 & 919 \\
$1987 \ldots \ldots \ldots$. & 634 & 205 & 47 & 886 \\
$1988 \ldots \ldots \ldots$. & 674 & 244 & 47 & 934 \\
$1989 \ldots \ldots .$. & 696 & 212 & 41 & 949 \\
\hline
\end{tabular}

Sources: Energy Information Administration, Energy Data Reports, "Crude Petroleum, Petroleum Products, and Natural Gas Liquids: 1980". Table 21, p. 27; Petroleum Supply Annual, Volume 2, 1981-1982; Petroleum Supply Annual, Volume 1, 1983-1989.

Table C10. Natural Gas Use at Reflneries, 1980-1989

\begin{tabular}{|c|c|}
\hline Year & $\begin{array}{c}\text { Milliun } \\
\text { Cubic Fe日t }\end{array}$ \\
\hline $\begin{array}{l}1980 \\
1981 \\
1982\end{array}$ & $\begin{array}{l}828,876 \\
650,873 \\
590,862 \\
572,854 \\
573,330 \\
487,830 \\
581,743 \\
604,873 \\
605,729 \\
612,948\end{array}$ \\
\hline
\end{tabular}

Sources: Energy Information Administration, Petroleum Supply Annual, Volume 1, 1983-1989; Petroleum Supply Annual, Volume 2, 1981-1982.; Energy Data Reports, "Crude Petroleum,

Petroleum Products, and Natural Gas Liquids: 1980", Table 18, p. 24.
Sources: Energy Information Administration, Petroleum Supply Annual, Volume 1, 1981-1989; Energy Data Reports, "Crude Petroleum, Petroleum Products, and Natural Gas Liquids: 1980", Table 18, p. 24.
387,373

299,283

297,365

313,363

315,393

1988

312,580

Note: Stock levels are as of December 31 
Table C11. Purchased Electrlcity Use at Refineries, 1980-1989

\begin{tabular}{|c|c|c|}
\hline Year & $\begin{array}{l}\text { Million } \\
\text { Kilowatthour }\end{array}$ & \\
\hline & : & \\
\hline $1980 \ldots \ldots \ldots \ldots \ldots$ & 32,865 & \\
\hline $1981 \ldots \ldots \ldots \ldots \ldots$ & 33,045 & \\
\hline $1982 \ldots \ldots \ldots \ldots \ldots$ & 30,519 & \\
\hline 1983 ............... & 29,693 & \\
\hline $1984 \ldots \ldots \ldots \ldots \ldots$ & 29,354 & \\
\hline $1985 \ldots \ldots \ldots \ldots$ & 28,123 & \\
\hline 1986 ................ & 33,949 & 1 \\
\hline $1987 \ldots \ldots \ldots \ldots . .$. & 38,522 & \\
\hline $1988 \ldots \ldots \ldots \ldots \ldots$ & 34,966 & \\
\hline $1989 \ldots \ldots \ldots \ldots$ & 31,621 & \\
\hline
\end{tabular}

Sources: Energy Information Administration, Energy Data Reports, "Crude Petroleum, Petroleum Products, and Natural Gas Liquids: 1980", Table 18, p. 24; Petroleum Supply Annual, Volume 2, 1981-1982.; Petroleum Supply Annual, Volume 1, 1983-1989.
Table C13. Domestic Refined Product Margins for FRS Companies, 1977-1988 (Dollars per Barrel)

\begin{tabular}{c|c|c}
\hline Year & $\begin{array}{c}\text { Refined Profit } \\
\text { Margin } \\
\text { (Current) }\end{array}$ & $\begin{array}{c}\text { Refined Profit } \\
\text { Margin } \\
\text { (Constant) }\end{array}$ \\
\hline 1977 & 0.64 & \\
1978 & 0.75 & 0.95 \\
1979 & 0.85 & 1.04 \\
1980 & 1.00 & 1.08 \\
1981 & 0.83 & 1.17 \\
1982 & 0.85 & 0.88 \\
1983 & 0.71 & 0.85 \\
1984 & 0.01 & 0.68 \\
1985 & 1.09 & 0.01 \\
1986 & 0.67 & 0.98 \\
1987 & 0.15 & 0.59 \\
1988 & 1.78 & 0.13 \\
\hline
\end{tabular}

a In 1982 dollars, calculated using implicit GNP price deflators. Source: Energy information Administration, Performance Profiles of Major Energy Producers 1977-1988.
Table C12. Coal Use at Reflnerles, 1982-1989

\begin{tabular}{c|c}
\hline & \\
Year & Thousand Short Tons \\
\hline & \\
$1982 \ldots \ldots \ldots \ldots$. & 383 \\
$1983 \ldots \ldots \ldots \ldots$. & 173 \\
$1984 \ldots \ldots \ldots \ldots$. & 347 \\
$1985 \ldots \ldots \ldots \ldots$. & 246 \\
$1986 \ldots \ldots \ldots \ldots$. & 234 \\
$1987 \ldots \ldots \ldots \ldots$. & 226 \\
$1988 \ldots \ldots \ldots \ldots$. & 192 \\
$1989 \ldots \ldots \ldots \ldots . .$. & 172 \\
\hline
\end{tabular}

Source: Energy Information Administration, Energy Data Reports, Crude Petroleum, Petroleum Products, and Natural Gas Liquids: $1980^{\prime \prime}$, Table 18, p. 24; Petroleum Supply Annual, Volume 2, 1981-1982; Petroleum Supply Annual, Volume 1, 1983-1989.

\begin{tabular}{|c|c|c|c|c|}
\hline Year & Consolidated & Production & $\begin{array}{c}\text { Refining/ } \\
\text { Marketing }\end{array}$ & \begin{tabular}{|c} 
Rate \\
Regulated \\
Pipelines \\
\end{tabular} \\
\hline 1977 & 100 & 73.8 & 17.6 & 9.5 \\
\hline 1978 & 100 & 70.4 & 17.4 & 12.9 \\
\hline 1979 & 100 & 70.5 & 17.2 & 12.4 \\
\hline 1980 & 100 & 77.0 & 14.1 & 9.4 \\
\hline 1981 & 100 & 84.7 & 6.4 & 8.8 \\
\hline 1982 & 100 & 77.0 & 10.5 & 12.3 \\
\hline 1983 & 100 & 76.9 & 10.3 & 12.7 \\
\hline 1984 & 100 & 83.7 & 0.7 & 15.8 \\
\hline 1985 & 100 & 72.4 & 13.7 & 13.9 \\
\hline 1986 & 100 & 17.5 & 31.6 & 50.1 \\
\hline 1987 & 100 & 56.4 & 12.7 & 30.8 \\
\hline 1988 & 100 & 29.9 & 51.4 & 18.7 \\
\hline
\end{tabular}

Note: Numbers may not add due to independent rounding. Source: Energy Information Administration, Performance Profiles of Major Energy Producers 1977-1988. 
Table C15. Domestic Refinery Energy Expense for FRS Companles, 1977-1988 (Dollars)

\begin{tabular}{|c|c|c|c|c|}
\hline \multirow[b]{2}{*}{ Year } & \multicolumn{2}{|c|}{$\begin{array}{l}\text { Total Refinery } \\
\text { Energy Expense }\end{array}$} & \multicolumn{2}{|c|}{$\begin{array}{c}\text { Refinery Energy } \\
\text { Expense per Barrel } \\
\text { of Output }\end{array}$} \\
\hline & Current & Constant $^{\mathrm{a}}$ & Current & Constant $^{\mathrm{a}}$ \\
\hline 1977 & 4,113 & 6,111 & 0.83 & 1.23 \\
\hline 1978 & 4,743 & 6,569 & 0.95 & 1.33 \\
\hline 1979 & 5,703 & 7,256 & 1.15 & 1.50 \\
\hline 1980 & 8,161 & 9,523 & 1.68 & 2.13 \\
\hline 1981 & 9,332 & 9,928 & 2.09 & 2.41 \\
\hline 1982 & 8,936 & 8,936 & 2.17 & 2.30 \\
\hline 1983 & 8,837 & 8,506 & 2.28 & 2.25 \\
\hline 1984 & 8,664 & 8,045 & 2.29 & 2.00 \\
\hline 1985 & 7,611 & 6,863 & 1.90 & 1.72 \\
\hline 1986 & 6,187 & 5,432 & 1.55 & 1.30 \\
\hline 1987 & 5,437 & 4,620 & 1.30 & 1.08 \\
\hline 1988 & 5,477 & 4,500 & 1.28 & $1.0 ?$ \\
\hline
\end{tabular}

a In 1982 dollars, calculated using implicit GNP price deflators. Source: Energy information Administration, Performance Profiles of Major Energy Producers 1977-1988.
Table C17. Number of U.S. Refining Companies by Major and Non-Major Company Ownership, 1980-1990

\begin{tabular}{|c|c|c|c|}
\hline Year & Major & Non-Major & Total U.S. \\
\hline 1980 & 23 & 165 & 188 \\
\hline 1981 & 23 & 166 & 189 \\
\hline 1982 & 23 & 152 & 175 \\
\hline 1983 & 23 & 119 & 142 \\
\hline 1984 & 22 & .111 & 133 \\
\hline 1985 & 21 & 93 & 114 \\
\hline 1986 & 20 & 94 & 114 \\
\hline 1987 & 20 & 94 & 114 \\
\hline 1988 & 19 & 84 & 103 \\
\hline 1989 & 18 & 88 & 106 \\
\hline 1990 & 18 & 90 & 108 \\
\hline
\end{tabular}

a Number of companies as of January 1 in each year. Note: Totals may not equal sum of components due to independent rounding.

Sources: Energy Information Administration, Energy Data Report, "Petroleum Refineries in the United States and U.S. Territories," and Petroleum Supply Annual 1981-1989, Refinery Statistics section.
Table C16. Additions to Investment for Domestic Petroleum Refining for FRS Companies, 1977-1988 (Dollars)

\begin{tabular}{c|c|c}
\hline & & \\
Year & Current & Constant $^{\mathrm{a}}$ \\
\hline & & \\
1977 & 1,029 & 1,529 \\
1978 & 1,430 & 1,981 \\
1979 & 2,221 & 2,826 \\
1980 & 2,547 & 2,972 \\
1981 & 4,041 & 4,299 \\
1982 & 4,973 & 4,973 \\
1983 & 3,695 & 3,556 \\
1984 & 3,681 & 3,418 \\
1985 & 2,380 & 2,148 \\
1986 & 1,752 & 1,538 \\
1987 & 1,920 & 1,631 \\
1988 & 3,675 & 3,020 \\
\hline
\end{tabular}

a In 1982 dollars, calculated using implicit GNP price deflators. Source: Energy Information Administration, Performance Profiles of Major Energy Producers 1977-1988.
Table C18. Crude OII Distillation Capacity by Major and Non-Major Company Ownership, 1980-1990 (Thousand Barrels per Day)

\begin{tabular}{c|c|c|c}
\hline Year & Major & Non-Major & rotal U.S. \\
\hline \multicolumn{4}{|c}{} \\
1980 & 14,012 & 3,976 & 17,988 \\
1981 & 14,146 & 4,475 & 18,621 \\
1982 & 13,534 & 4,356 & 17,890 \\
1983 & 12,877 & 3,983 & 16,859 \\
1984 & 12,139 & 3,998 & 16,137 \\
1985 & 12,125 & 3,534 & 15,659 \\
1986 & 11,654 & 3,805 & 15,459 \\
1987 & 11,594 & 3,971 & 15,566 \\
1988 & 11,454 & 4,461 & 15,915 \\
1989 & 10,608 & 5,047 & 15,655 \\
1990 & 10,159 & 5,413 & 15,572 \\
\hline
\end{tabular}

"Crude distillation capacity as of January 1 in each year. Note: Totals may not equal sum of components due to indepentent rounding.

Sources: Energy Information Administration, Energy Data Report, "Petroleum Reineries in the United States and U.S. Territories," and Petroleum Supply Annual 1981-1989, Refinery Statistics section. 
Table C19. Number of U.S. Refinerles by Major and Non-Major Company Ownership, 1980-1990

\begin{tabular}{c|c|c|c}
\hline & & & \\
Year & Major & Non-Major & Total U.S. \\
\hline & & & \\
1980 & 122 & 197 & 319 \\
1981 & 121 & 203 & 324 \\
1982 & 114 & 187 & 301 \\
1983 & 107 & 151 & 258 \\
1984 & 102 & 145 & 247 \\
1985 & 100 & 123 & 223 \\
1986 & 95 & 121 & 216 \\
1987 & 90 & 129 & 219 \\
1988 & 88 & 125 & 213 \\
1989 & 83 & 121 & 204 \\
1990 & 80 & 125 & 205 \\
\hline
\end{tabular}

a Number of refineries as of January 1 in each year. Note: Totals may not equal sum of components due to independent rounding.

Sources: Energy Information Administration, Energy Data Report, "Petroleum Refineries in the United States and U.S. Territories," and Petroleum Supply Annual 1981-1989, Refinery Statistics section.
Table C21. Petroleum Product Supplled, 1980-2000

(Million Barrels per Day)

\begin{tabular}{l|c|c|c|c|c|c}
\hline Year & $\begin{array}{c}\text { Motor } \\
\text { Gasollne }\end{array}$ & $\begin{array}{c}\text { Jet } \\
\text { Fuel }\end{array}$ & $\begin{array}{c}\text { Distillate } \\
\text { Fuel Oll }\end{array}$ & $\begin{array}{c}\text { Residual } \\
\text { Fuel Oll }\end{array}$ & Other & Total \\
\hline 1980 & 6.58 & 1.07 & 2.87 & 2.51 & 4.04 & 17.06 \\
1985 & 6.83 & 1.22 & 2.87 & 1.20 & 3.61 & 15.73 \\
1990 & 7.41 & 1.50 & 3.17 & 1.19 & 4.14 & 17.41 \\
1995 & 7.52 & 1.62 & 3.29 & 1.47 & 4.31 & 18.21 \\
2000 & 7.71 & 1.73 & 3.38 & 1.49 & 4.54 & 18.84 \\
\hline
\end{tabular}

Source: 1980-1985: Energy Information Administratlon, Annual Energy Reviow, 1988; 1990-2000: Annual Energy Outlook, 1990.

Table C20. U.S. Crude Oll DIstlllation Capacity by Forelgn-Afflliated and U.S. Owned Companles, $1980-1988^{\circ}$

(Thousand Barrels per Day)

\begin{tabular}{c|c|c|c}
\hline Year & $\begin{array}{c}\text { Forelgn- } \\
\text { Affiliated }\end{array}$ & U.S. Owned & $\begin{array}{c}\text { Total U.S. } \\
\text { Capacity }\end{array}$ \\
\hline \multicolumn{4}{c}{} \\
1980 & 2,066 & 16,555 & 18,621 \\
1981 & 2,595 & 15,295 & 17,890 \\
1982 & 2,423 & 14,436 & 16,859 \\
1983 & 2,337 & 13,800 & 16,137 \\
1984 & 2,276 & 13,383 & 15,659 \\
1985 & 2,656 & 12,803 & 15,459 \\
1986 & 3,133 & 12,433 & 15,566 \\
1987 & 3,342 & 12,573 & 15,915 \\
1988 & 4,247 & 11,408 & 15,655 \\
\hline
\end{tabular}

a Crude distillation capacity as of December 31 in each year. Note: Totals may not equal sum of components due io independent rounding.

Sources: Energy Information Administration, Profiles of Foreign Direct Investment in U.S. Energy 1983, p. 17; and Profiles of

Foreign Direct Investment in U.S. Energy 1988, p. 17. 


\section{Financial Reporting System}

Since 1977, the EIA has collected financial and operating data from the Nation's largest integrated oil companies through the Financial Reporting System (FRS). The FRS is designed to track the overall performance of major energyproducing companies, as well as their performance by operating segment and geographic area. To be included in the FRS survey, an energy company must account for at least 1 percent of either total production or reserves of oil, gas, coal, or uranium, or 1 percent of domestic refining capacity or petroleum product sales. Because of mergers, acquisitions, spinoffs, and modified selection criteria applied in 1982, the number of companies reporting to FRS has varicd from year to year. EIA initially selected 27 of the largest 50 publicly owned crude oil producers in 1976 who met the above criteria. In 1988, the latest year for which FRS financial data are available, 23 companies filed financial and operating information with EIA.

Financial data are submitted by selected companies using Form EIA-28. The financial reporting schedules in Form EIA-28 are structured to obtain data on revenues, costs, and profits, and depict financial flows and performance characteristics for any given annual reporting period. The form also collects balance sheet data as well as data on new investment. To complement the finaricial data, a series of operating and statistical schedules are included to track physical activity patterns and to evaluate several operational and financial relationships.

Domestic petroleum lines-of-business data are divided into three segments: production, refining/marketing, and rate regulated pipelines. Each segment is presented as though it were a separate entity entering into transactions with other segments and third parties. The domestic refining/marketing segment, the focus of this chapter, purchases raw matcrials from U.S. production, foreign refining/marketing, and third parties for refining and sale to third parties. The refining/marketing segment also makes purchases directly from foreign producers for those companies that do not have foreign refining/marketing assets. The U.S. production segment includes production and sales of crude oil, natural gas liquids (NGLs), and natural gas. The segment covering rate-regulated pipelines includes the transport of crude oil, NGLs, and natural gas through Federal or State regulated pipelines.

The 23 companies included in the FRS survey for 1988 occupied a major position in the U.S. economy. In 1988, these companies were responsible for 20 percunt of the sales, 23 percent of the profits, and 21 percent of the assets of Fortune's 500 largest iudustrial corporations. FRS companies accounted for 59 percent of total domestic crude oil and natural gas liquids production, 46 percent of U.S. natural gas production, and 76 percent of U.S. refining capacity. In addition, FRS companies devoted $\$ 437.5$ billion, 76 percent of their allocated revenues, to sustaining various aspects of petroleum production, refining, marketing, and transportation. Of the 23 energy companies reporting to the FRS survey in 1988,20 were engaged in petroleum refining.

The FRS companies account for a significant portion of domestic refinery capacity. During the 1980's, the share of total U.S. refining capacity and refinery output attributed to FRS companies ranged from 75 to 80 percent. The number of active refineries operated by FRS companies declined throughout the decade, leading to a substantial decrease in operable capacity. At the beginning of the decade, FRS companies reported 121 operable refineries with 14.4 million barrels per day of capacity. By 1989, the number of operable refineries owned by FRS companies was reduced to 91 with a combined distillation capacity of 12.3 million barrels per day. These declines in the number and capacity of FRS refineries reflects the general trend in domestic refining in the 1980's. Despite the decrease in distillation capacity, however, the sophistication of FRS refineries increased measurably over the period. 


\section{Glossary}

Alcohol. The family name of a group of organic chemical compounds composed of carbon, hydrogen, and oxygen. The series of molecules vary in chain length and are conıposed of a hydrocarbon plus a hydroxyl group; $\mathrm{CH}-(\mathrm{CH})_{\mathrm{n}^{-}}$ $\mathrm{OH}$ (e.g., methanol, ethanol, and tertiary butyl alcohol (TBA)).

Alcohol Fuel. Lower alcohols used as blending agents in gasoline, particularly where petroleum is scarce or gasoline is low in octane number.

Alkytation. A refining process for chemically combining isobutane with olefin hydrocarbons (e.g., propylene, butylene) through the control of temperature and pressure in the presence of an acid catalyst, usually sulfuric acid or hydrofluoric acid. The product alkylate, an isoparaffin, has high octane value and is blended with motor and aviation gasoline to improve the antiknock value of the fuel.

API Gravity. An arbitrary scale expressing the gravity or density of liquid petroleum products. The measuring scale is calibrated in terms of degrees API. The higher the API gravity, the lighter the compound. Light crudes generally p. - ced 38 degrees API and heavy crudes are commonly labeled as all crudes with an API gravity of 22 degrees or below. Intermediate crudes fall in the range of 22 to 38 degrees API gravity.

Aromatics. Hydrocarbons characterized by unsaturated ring structures of carbon atonis. Commercial petroleum aromatics are benzene, toluene, and xylene (BTX).

Asphalt. A dark-brown-lo-black cement-like material containing bitumens as the predominant constituents, obtained by petroleum processing. Includes crude asphalt as well as the following finished products: cements, fluxes, the asphalt content of emulsions (exclusive of water), and petroleum distillates blended with asphalt to make cutback asphalts.

Atmospheric Crude Oil Distillation. The refining process of separating crude oil components at atmospheric pressure by heating to temperatures of about 600 to 750 degrees Fahrenheit (depending on the nature of the crude oil and desired products) and subsequent condensing of the fractions by cooling.
Aviation Gasoline. Special grades of gasoline for use in aviation reciprocating engines. Finished aviation gasoline excludes blending components (e.g., straight-run gasoline, alkylate, and reformate) which will be used for blending or compounding into finished aviation gasoline.

Barrel. A volumetric unit of measure for crude oil and petroleum products equivalent to 42 U.S. gallons.

Barrels Per Calendar Day. The maximum number of barrels of input that can be processed during a 24-hour period after making allowances for the following limitations:

the capability of downstream facilities to absorb the output of crude oil processing facilities of a given refinery. No reduction is made when a planned distribution of intermediate streams through other than downstream facilities is part of a refinery's normal operation;

the types and grades of inputs to be processed;

the types and grades of products expected to be manufactured;

the environmental constraints associated with refinery operations;

the reduction of capacity for scheduled downtime such as routine inspection, mechanical problems, maintenance, repairs, and turnaround; and

the reduction of capacity for unscheduled downtime such as mechanical problems, repairs, and slowdowns.

Barrels Per Stream Day. The amount a unit can process running at full capacity under optimal crude oil and product slate conditions.

Benzene. An aromatic hydrocarbon, $\left(\mathrm{C}_{6} \mathrm{H}_{6}\right)$, present to a minor degree in most crude oils. Some important producis manufactured from benzene are: styrene, phenol, nylon, aniline, and synthetic detergents.

Blending Stock. Any of the stocks used to make commercial gasoline. These include natural gasoline, straight-run 
gasoline, cracked gasoline, polymer gasoline, alkylate, and aromatics.

Boiling Range. The range of temperature, usually determined at atmospheric pressure in standard laboratory ap. paratus, over which the boiling or distillation of an oil commences, procecds, and finishes.

Bulk Terminal. A facility used primarily for the storage and/or marketing of petroleum products which has a total bulk storage capacity of 50,000 barrels or more and/or receives petrolcum products by tanker, barge, or pipeline.

Butane. A normally gaseous straight-chain or branchchain hydrocarbon, $\left(\mathrm{C}_{4} \mathrm{H}_{10}\right)$. It is extracted from natural gas or refinery gas streams. It includes isobutane and normal butane.

Isobutane. A normally gascous branch-chain hydrocarbon, $\left(\mathrm{C}_{4} \mathrm{H}_{10}\right)$. It is a colorless paraffinic gas that boils at a temperature of 10.9 degrees Fahrenheit. It is extracted from natural gas or refinery gas streams.

Normal Butane. A normally gaseous straight-chain hydrocarbon, $\left(\mathrm{C}_{4} \mathrm{H}_{10}\right)$. It is a colorless paraffinic gas that boils at a temperature of 31.1 degrees Fahrenheit. It is extracted from natural gas or refincry gas streams.

Butylene. An olefinic hydrocarbon, $\left(\mathrm{C}_{4} \mathrm{H}_{8}\right)$, recovered from refinery processes.

Catalyst. A substance which affects, provokes, or accelerates reactions without itself being altered.

Catalytic Cracking. The refining process of breaking down the larger, heavier, and more complex hydrocarbon molecules into simpler and lighter moiecules. Catalytic cracking is accomplished by the use of a catalytic agent and is an effective process for increasing the yield of gasoline from crude oil. Catalytic cracking processes fresh feeds and recycled feeds.

Fresh Feeds. Crude oil or petroleum distillates which are being fed to processing units for the first time.

Recycled Feeds. Fecds that are continuously fed back for additional processing.

Catalytic Hydrocracking. A refining process that uses hydrogen and catalysts with relatively low temperatures and high pressures for converting middle boiling or residual material to high-octane gasoline, reformer charge stock, jet fuel and/or high grade fuel oil. The process uses one or more catalysts, depending upon product output, and can handle high sulfur feedstocks without prior desulfurization.

Catalytic Hydrotreating. A refining process for treating potroleum fractions from atmospheric or vacuum distilla. tion units (c.g., naphthas, middle distillates, reformer feeds, residual fucl oil, and heavy gas oil) and other petroleum (e.g., cat cracked naphtha, coker naphtha, gas oil, etc.) in the presence of catalysts and substantial quantities of hydrogen. Hydrotreating includes desulfurization, removal of substances (e.g., nitrogen compounds) that deactivate catalysts, conversion of olefins to paraffins to reduce gum formation in gasoline, and other processes to upgrade the quality of the fractions.

Catalytic Reforming. A refining process using controlled heat and pressure with catalysts to rearrange cortain hydrocarbon molecules, thereby converting paraffinic and naphthenic type hydrocarbons (e.g., low-octane gasoline boiling range fractions) into petrochemical feedstocks and higher octane stocks suitable for blending into finished gasoline.

Charge Capacity. The input (feed) capacity of the refinery processing facilities.

Coking. Thermal refining processes used to produce fuel gas, gasoline blendstocks, distillates, and petroleum coke from the heavier products of atmospheric and vacuum distillation. Includes:

Delayed Coking. A process by which heavicr crude oil fractions can be thermally decomposed under conditions of elevated temperatures and pressure to produce a mixture of lighter oils anci petrolcum coke. The light oils can be processed further in other refinery units to meet product specifications. The coke can be used either as a fucl or in other applications such as the manufacturing of stecl or aluminum.

Flexicoking. A thermal cracking process which converts heavy hydrocarbons such as crude oil, tar sands bitumen, and distillation residues into light hydrocarbons. Fecdstocks can be any pumpable hydrocarbons including those containing high concentrations of sulfur and metals.

Fluid Coking. A thermal cracking process utilizing the fluidized-solids technique to remove carbon (coke) for continuous conversion of heavy, low-grade oils into lighter products.

Contributions to Net Income. The FRS segment equivalent of net income. However, many consolidated items of revenue and expense are not allocated to the segments, and 
therefore they are not equivalent in a strict sense. The largest item not allocated to the segments is interest expense since this is regarded as a corporate-level item for FRS purposes.

Crude Oil (including Lease Condensate). A mixture of hydrocarbons that exists in liquid phase in underground reservoirs and remains liquid at atmospheric pressure after passing through surface-separating facilities. Included are lease condensate and liquid hydrocarbons produced from tar sands, gilsonite, and oil shale. Drip gases are also included, but topped crude oil (residual oil) and other unfinished oils are excluded. Liquids produced at natural gas processing plants and mixed with crude oil are likewise excluded where identifiable. Crude oil is considered as elther domestic or foreign, according to the following:

Domestic. Crude oil produced in the United States or from its "outer continental shelf?"

Foreign. Crude oil produced outside the United States.

Crude Oil Losses. Represents the volume of crude oil reported by petroleum refineries as being lost in their operations. These losses are due to spills, contamination, fires, ctc. as opposed to refinery processing losses.

Crude Oil Qualities. Refers to two properties of crude oil, the sulfur content and API gravity, which affect processing complexity and product characteristics.

Crude Oil Used Directly. Represents the amount of crude oil consumed as fuel by crude oil pipelines and on crude oil leases.

Deasphalting. See solvent deasphalting.

Desulfurization. The removal of sulfur or sulfur compounds from a charge stock.

Development Well. A well drilled within the proved area of an oil or gas rescrvoir to the depth of a stratigraphic horizon known to be productive.

Distillate Fuel Oil. A general classification for one of the petrolcum fractions produced in conventional distillation operations. It is used primarily for space heating, on-andoff-highway diesel engine fuel (including railroad engine fuel and fuel for agricultural machinery), and electric power generation. Included are producis known as No. 1, No. 2, and No. 4 fuel oils; No. 1, No. 2, and No. 4 diesel fuels.

No. I Fuel Oil. A light distillate fuel oil intended for use in vaporizing pot-type burners.
No. 2 Fuel Oil. A distillate fuel oil for use in atomizingtype burners for domestic heating or for moderate capacity commercial-industrial burner units.

No. 1 and No. 2 Diesel Fuel Oils. Distillate fuel oils used in compression-ignition engines:

No. 1-D. A volatile distillate fucl oil for use in high-specd diesel engines generally operated under variations in specd and load. Includes type C-B diesel fuel used for city buses and similar operations.

No. 2-D. A gas oil type distillate of lower volatility for use in high-speed diesel engines generally operated under uniform speed and load conditions. Includes Type R-R diesel fucl used for railroad locomotive engines, and Type T-T for diesel-engine trucks.

No. 4 Fuel Oil. A fuel oil for commercial burner installations not equipped with preheating facilities. It is used extensively in industrial plants. This grade is a blend of distillate fuel oil and residual fuel oil stocks. Also included is No. 4-D, a fuel oil for low and inedium-speed diesel engines.

Ethane. A normally gascous straight-chain hydrocarbon, $\left(\mathrm{C}_{2} \mathrm{H}_{6}\right)$. It is a colorless paraffinic gas that boils at a temperature of -127.48 degrees Fahrenheit. It is extracted from natural gas and refinery gas streams.

Ether. A generic term applied to a group of organic chemical compounds composed of carbon, hydrogen, and oxygen, characterized by an oxygen atom attached to two carbon atoms (e.g., methyl tertiary hutyl ether).

Ethylene. An olefinic hydrocarbon, $\left(\mathrm{C}_{2} \mathrm{H}_{4}\right)$, recovered from refinery processes or petrochemical processes.

Exploratory Well. A well drilled to find and produce oil or gas in an unproved area; to find a new reservoir in a field previously found to be productive of oil or gas in another reservoir; or to extend the limit of a known oil or gas reservoir.

Exports. Shipments of goods from the 50 States and the District of Columbia to foreign countries, Puerto Rico, the Virgin Islands, and other U.S. possessions and territories.

Extensions. The reserves credited to a reservoir because of enlargement of its proved area. Normally the ultimate size of newly discovered fields, or newly discovered reservoirs in old fields, is determined by wells drilled in years subsequent to discovery. When such wells add to the proved 
area of a previously discovered reservoir, the increase in proved reserves is classified as an extension.

Feedstock. Crude oil or a fraction thereof to be charged to any process equipment.

Field. An area consisting of a single reservoir or multiple reservoirs all grouped on, or related to, the same individual geological structural feature and/or stratigraphic condition. There may be two or more reservoirs in a field that are separated vertically by intervening impervious strata, or laterally by local geologic barriers, or by both.

First Purchase (of crude oil). An equity (not custody) transaction involving an arms-length transfer of ownership of crude oil associated with the physical reinoval of the crude oil from a property (lease) for the first time. A first purchase normally occurs at the time and place of ownership transfer where the crude oil volume sold is measured and recorded on a run ticket or other similar physical evidence of purchase. The reported cost is the actual amcunt paid by the purchaser, allowing for any adjustments (deductions or premiums) passed on to the producer or royalty owner.

Fuels Solvent Deasphalting. A refining process for removing asphalt compounds from petroleum fractions, such as reduced crude oil. The recovered stream from this process is used to produce fuel products.

Gas Oils. Liquid petrolcum distillates with viscosity between that of kerosene and lubricating oil. The "gas oil" name is derived from the original use of these oils in the manufacture of illuminating gas. Gas oils are now used to produce distillate fucl oils and gasoline. Included are:

Heavy Gas Oils. Petroleum distillates with an approximate boiling range from 651 to 1000 degrees Fahrenheit.

Light Gas Oils. Liquid petroleum distillates heavier than naphtha, with an approximate boiling ange from 401 to 650 degrees Fahrenheit.

Gasoline Blending Components. Naphthas which will be used for blending or compounding into finished aviation or motor gasoline (e.g., straight-run gasoline, alkylate, and reformate). Excludes oxygenates (alcohols, ethers), butane, and pentanes plus.

Gasoline Prol. A planning concept which considers gasolines of various qualities as one group for the purpose of biending to meet final product specifications.
Gross Input to Atmospheric Crude Oil Distillation Units. Total input to atmospheric crude oil distillation units. Includes all crude oil, lease condensate, natural gas plant liquids, unfinished oils, liquefied refinery gases, slop oils, and other liquid hydrocarbons (such as shale oil, tar sand oils, gilsonite, etc.).

Hydrocracking. See catalytic hydrocracking.

Hydrogen. The lightest of all gases, occurring chiefly in combination with oxygen in water; also in acids, bases, alcohols, petroleum, and oiher hydrocarbons.

Hydrotreating. See catalytic hydrotreating.

Idle Capacity. The component of operable capacity that is not in operation and not under active repair, but capable of being placed in operation within 30 days; and capacity not in operation but under active repair that can be completed within 90 days.

Imports. Receipts of goods into the 50 States and the District of Columbia from foreign countries, Puerto Rico, the Virgin Islands, and other U.S. possessions and territories.

Indicated Additional Reserves of Crude Oil. Quantities of crude oi: (other than proved reserves) which may become economically recoverable from existing productive reservoirs through the application of improved recovery techniques using current technology. These recovery techniques inay:

already be installed in the reservoir, but their effects are not yet known to the degree necessary to classify the additional reserves as proved, or

be installed in another similar reservoir, where the results of that installation can be used to estimate the indicated additional reserves.

Indicated additional reserves are not included in proved reserves due to their uncertain economic recoverability. When economic recoverability : demonstrated, the indicated additional reserves must se transferred to proved reserves as positive revisions.

Isobutane. Sce Butane.

Isomerization. A refining process which alters the fundamental arrangement of atoms in the molecule without adding or removing anything from the original material. Used to convert normal butane into isobutane $\left(\mathrm{C}_{4}\right)$, an 
alkylation process feedstock, and normal pentane and hexane into isopentane $\left(\mathrm{C}_{5}\right)$ and isohexane $\left(\mathrm{C}_{6}\right)$, high-octane gasoline components.

Isopentane. See Natural Gasoline and Isopentane.

Jet Fuel. Includes kerosene-type jet fuel and naphtha-type jet fuel.

Kerosene-Type Jet Fuel. A quality kerosene product with a maximum distillation temperature of 400 degrees Fahrenheit at the 10-percent recovery point and a final maximum boiling point of 572. A relatively low-freezing point distillate of the kerosene type used primarily for commercial turbojet and turboprop aircraft engines.

Naphtha-Type Jet Fuel. A fuel in the heavy naphtha boiling range used for turbojet and turboprop aircraft engines, primarily by the military. Excludes ram-jet and petroleum rocket fuels.

Kerosene. A petroleum distillate that has a maximum distillation temperature of 401 degrees Fahrenheit at the 10percent recovery point, a final boiling point of 572 degrees Fahrenheit, and a minimum flash point of 100 degrees Fahrenheit. Included are No. $1-\mathrm{K}$ and No. $2-\mathrm{K}$, and all grades of kerosene called range or stove oil. Kerosene is used in space heaters, cook stoves, and water heaters and is suitable for use as an illuminant when burned in wick lamps.

Lease Condensate. A natural gas liquid recovered from gas well gas (associated and non-associated) in lease separators or natural gas field facilities. Lease condensate consists primarily of pentanes and heavier hydrocarbons.

Light Ends. The lower boiling components of a mixture of hydrocarbons.

Liquefied Petroleum Gases (LPG). Ethane, ethylene, propane, propylene, normal butane, buty!ene, and isobutane produced at refineries or satural ras processing plants, including plants that fractionate $r * v$ natural gas plant liquids.

Liquefied Refinery Gases (LRG). Liquefied petroleum gases fractionated from refinery or still gases. Through compression and/or refrigeration, they are retained in the liquid state. Iricluded are ethane/ethylene, propane/ propylene, normal butane, butylene, and isobutane. Excludes still gas.

Lubricants. Subztances used to reduce friction between bcaring surfaces or incorporated into other tnaterials used as processing aids in the manufacturing of other products or as carriers of other materials. Petroleum lubricants may be produced either from distillates or residues. Other substances may be added to impart or improve certain required propertics. "Lubricants" includes all grades of lubricating oils from spindle oil to cylinder oil and those used in greases.

Motor Gasoline (Finisinetd). A complex mixture of relatively volatile hydrocarbons, with or without small quantities of additives, that has been blended to form a fuel suitable for use in spark-ignition engines. Motor gasoline includes a range in distillation tem $\mathrm{m}_{\mathrm{l}}$.ratures from 122 to 158 degrees Fahrenheit at the 10-percent recovery point and from 365 to 374 degrees Fahrenheit at the 90-percent recovery point. The Reid Vapor Pressure ranges from 9 to $15 \mathrm{psi}$. "Motor gasoline" includes finished leaded gasoline, finished unleaded gasoline, and gasohol (a blenci of gasoline and alcohol, limited to 10 percent volume of alcohol.)

Motor Gasoline Blending Components. Naphthas which will be used for blending or compounding into finished motor gasoline (c.g. straight-run gasoline, alkylate, and reformate). Excludes oxygenates (alcohols, ethers), butane, and pentanes plus.

Naphtha. A generic term applied to a petroleum fraction with an approximate boiling range between 122 and 400 degrees Fahrenheit.

Natural Gas. A mixture of hydrocarbons and small quantities of various nonhydrocarbons existing in the gascous phase or in solution with crude oil in underground reservoirs.

Natural Gas Liquids Production. The volume of natural gas liquids removed from natural gas in lease separators, field facilities, gas processing plants or cycling plants during the report year.

Natural Gas Plant Liquids. Natural gas liquids recovered from natural gas in gas processing plants, and in some situations, from natural gas field facilities. Natural gas liquids extracted by fractionators are also included. These liquids are classified as follows: cthane, propane, normal butane, isobutane, pentanes plus, and other products from natural gas processing plants (i.e., products meeting the standards for finished petrolcum products produced at natural gas processing plants, such as finished moto. gasoline, finished aviation gasoline, special naphthas, kerosene, distillate fuel oil, and miscellaneous products).

Natural Gas Processing Plant. A gas processing plant is a facility designed (1) to achieve the recovery of natural gas liquids from the stream of natural gas which may or may 
not have been processed through lease separators and field facilities, and (2) to control the quality of the natural gas to be marketed. Cycling plants are classified as gas processing plants.

Natural Gasoline and Isopentane. A mixture of hydrocarbons, mostly pentanes and heavier, extracted from natural gas, that mects vapor pressure, end-point, and other specifications for natural gasoline set by the Gas Processors Association. Includes isopentane which is a saturated branch-chain hydrocarbon, $\left(\mathrm{C}_{5} \mathrm{H}_{12}\right)$, obtained by fractionation of natural gasoline or isomerization of normal pentane.

Net Investment in Place. The sum of net property, plant, and equipment (PP\&E) plus investment and advances to unconsolidated affiliates.

Normal Butane. See Butane.

OPEC. The acronym for the Organization of Petroleum Exporting Countries, that have organized for the purpose of negotiating with oil companies on matters of oil production, prices and future concession rights. Current members are Algeria, Ecuador, Gabon, Indonesia, Iran, Iraq, Kuwait, Libya, Nigeria, Qatar, Saudi Arabia, United Arab Emirates, and Venezuela. The Neutral Zone between Kuwait and Saudi Arabia is considered part of OPEC.

Operable Capacity. The amount of capacity that, at a given date, is in operation; not in operation and not under active repair, but capable of being placed in operation within 30 days; or not in operation but under active repair that can be completed within 90 days. Operable capacity is the sum of the opcrating and idle capacity and is measured in barrels per calendar day or barrels per stream day.

Operating Capacity. The component of operable capacity that is in operation at a given date.

Operating Ratio. Represents the utilization of the atmospheric crude oil distillation units. The ratio is calculated by dividing the gross input to these units by the operable refining capacity of the units.

Oxygenates. Oxygenates include both alcohols and ethers used as octane boosting additives for gasoline (e.g., methyl tertiary butyl ether).

Pentanes Plus. A mixture of hydrocarbons, mostly pentanes and heavier, extracted from: natural gas. Includes isopentane, natural gasoline, and plant condensate.

Petrochemical Feedstocks. Chemical feedstocks derived from petrolcum principally for the manufacture of chemi- cals, synthetic rubber, and a variety of plastics. Included are naphtha with a boiling range of less than 401 degrees Fahrenheit and oils with a boiling range equal to or greater than 401 degrees Fahrenheit intended for use as petrochemical feedstocks.

Fetroleum Coke. A residue, the final product of the condensation process in cracking. Included are:

Marketable Coke. Those grades of coke produced in delayed or fluid cokers which may be recovered as relatively pure carbon. This "grcen" coke may be sold as is or further purified by calcining.

Catalyst Coke. In many catalytic operations (e.g., catalytic cracking) carbon is deposited on the catalyst, thus deactivating the catalyst. The catalyst is reactivated by burning off the carbon, which is used as a fuel in the refining process. This carbon or coke is not recoverable in a concentrated form.

Petroleum Products. Petroleum products are obtained from the processing of crude oil (including lease condensate), natural gas, and other hydrocarbon compounds. Petroleum products include unfinished oils, liquefied petroleum gases, pentanes plus, aviation gasoline, motor gasoline, naphtha-type jet fuel, kerosene-type jet fuel, kerosene, distillate fuel oil, residual fuel oil, petrochemical feedstocks, special naphthas, lubricants, waxes, petroleum coke, asphalt, road oil, still gas, and miscellaneous products.

Pipeline, Rates Regulated. FRS establishes three pipeline segments; crude/liquid (raw materials); natural gas; and refined products. The pipelines included in these segments are all federally or state rate-regulated pipeline operations, which are included in the reporting company's consolidated financial statements. However, at the reporting company's option intrastate pipeline operations may be included in the U.S. Refining/Marketing Segment if: they would comprise less than 5 percent of U.S. Refining/Marketing Segment net PP\&E, revenues and earnings in the aggregate; and if the inclusion of such pipelines in the consolidated financial statements adds less than $\$ 100$ million to the net PP\&E reported for the U.S. Refining/Marketing Segment.

Plant Condensate. One of the natural gas liquids, mostly pentanes and heavier hydrocarbons, recovered and separated as liquids at gas inlet separators or scrubbers in prucessing plants.

Processing Gain. The volumetric amount by which total refinery output is greater than input for a given period of time. This difference is due to the processing of crude oil 
into products which, in total, have a lower specific gravity than the crude oil processed.

Processing Loss. The volumetric amount by which total refinery output is less than input for a given period of time. This difference is due to the processing of crude oil into products which, in total, have a higher specific gravity than the crude oil processed.

Production Capacity. The amount of product that can be produced from processing facilitics.

Production, Crude Oil. The volume of crude oil extracted from oil reservoirs during given periods of time. The amount of such production for a given period is measured as volumes delivered from lease storage tanks (i.e., the point of custody transfer) to pipelines, trucks, or other media for transport to refineries or terminals with adjustments for (1) net differences between opening and closing lease inventories, and (2) basic sediment and water (BS\&W).

Products Supplied. Approximately represents consumption of petroleum products because it measures the disappearance of these products from primary sources, i.e., refineries, natural gas processing plants, blending plants, pipelines, and bulk tcrminals. In general, product supplied for each product in any given period is computed as follows: field production, plus refinery production, plus imports, plus unaccounted for crude oil, minus stock change, minus crude oil losses, minus refinery inputs, minus exports.

Propane. A normally gaseous straight-chain hydrocarbon, $\left(\mathrm{C}_{3} \mathrm{H}_{8}\right)$. It is a colorless paraffinic gas that boils at a temperature of -43.67 degrees Fahrenheit. It is extracted from natural gas or refinery gas streams. It includes commercial propane and HD-5 propane.

Propylene. An olefinic hydrocarbon, $\left(\mathrm{C}_{3} \mathrm{H}_{6}\right)$, recovered from refinery processes or petrochemical processes.

Proved Reserves of Crude Oil. Proved reserves of crude oil as of December 31 of a given year are the estimated quantities of all liquids defined as crude oil, which geological and engineering data demonstrate with reasonable certainty to be recoverable in future years from known reservoirs under existing economic and operating conditions.

Reservoirs are considered proved if economic producibility is supported by actual production or conclusive formation test (drill stem or wire line), or if er:onomic producibility is supported by core analyses and/or electric or other log interpretations. The area of an oil reservoir considered proved includes (1) that portion delincated by ditling and defined by gas-oil and/or oil-water contacts, if any; and (2) the immediately adjoining portions not yet drilled, but which can be reasonably judged as economically productive on the basis of available geological and engineering data.

Reserves of crude oil which can be produced economically through application of improved recovery techniques (such as fluid injection) are included in the "proved" classification when successful testing by a pilot project, or the operation of an installed program in the reservoir, provides support for the engineering analysis on which the project or program was based.

Estimates of proved crude oil reserves do not include the following: (1) oil that may become available from known reservoirs but is reported separately as "indicated additional reserves"; (2) natural gas liquids (including lease condensate); (3) oil, the recovery of which is subject to reasonable doubt because of uncertainty as to geology, reservoir characteristics, or economic factors; (4) oil that may occur in undrilled prospects; and (5) oil that may be recovered from oil shales, coal, gilsonite, and other such sources. It is not necessary that production, gathering or transportation facilities be installed or operative for a reservoir to be considered proved.

Proved Reserves of Natural Gas Liquids. Proved reserves of natural gas liquids as of December 31 of a given year are those volumes of natural gas liquids (inciuding lease condensate) demonstrated with reasonable certainty to be separable in the future from proved natural gas reserves under existing economic and operating conditions.

Recycle. A type of operation in which part of the product is continuously fed back for reprocessing, in contrast to once-through operation. Also, that portion of the product which is fed back.

Reduced Crude. A residual product remaining after the removal, by distillation or other means, of an appreciable quantity of the more volatile components of crude oil.

Refiner Acquisition Cost. The cost of crude oil to the refiner, including transportation and fees. The composite cost is the weighted average of domestic and imported cre te oil costs.

Refinery. An installation that manufactures finished petroleum products from crude oil, unfinished oils, natural gas liquids, other hydrocarbons, and alcohol.

Refinery Capacity Utilization. Ratio of the total amount of criude oil, unfinished oils, and natural gas plant liquids run 
through crude oil distillation units to the operable capacity of these units.

Refinery Input, Crude Oil. Total crude oil (domestic plus forcign) input to crude oil distillation units and other refinery processing units (cokers, etc.).

Refinery Input, Total. The raw materials and intermediate materials processed at refineries to produce finished petroleum products. They include crude oil, products of natural gas processing plants, unfinished oils, other hydrocarbons and alcohol, motor gasoline and aviation gasoline blending components and finished petroleum products.

Refinery Production. Petroleum products produced at a refinery or blending plant. Published production of these products equals refinery production minus refinery input.

Refinery Utilization Rate. Represents the utilization of the atmospheric crude oil distillation units. The rate is calculated by dividing the gross input to these units by the operable refining capacity of the units.

Refinery Yield. Refinery yield (expressed as a percentage) represents the percent of finished product produced from input of crude oil and net input of unfinished oils. It is calculated by dividing the sum of crude oil and net unfinished input into the individual net production of finished products. Before calculating the yield for finished motor gasoline, the input of natural gas liquids, other hydrocarbons and alcohol, and net input of motor gasoline blending components must be subtracted from the net production of finished motor gasoline. Before calculating the yield for finished aviation gasoline, input of aviation gasoline blending components must be subtracted from the net production of finished aviation gasoline.

Reseller. A firm (other than a refiner) that carries on the trade or business of purchasing refined petroleum products and reselling them without substantially changing their form to purchasers other than ultimate consumers.

Reseller/Retailer. A firm (other than a refiner) that carries on the trade or business activities of both a reseller and a retailer; i.e., purchasing refined petroleum products and reselling them without substantially changing their form to purchasers who may be either ultimate or other than ultimate consumers.

Reserve Changes. Positive and negative revisions, extensions, new reservoir discoveries in old fields, and new field discouaries, which necurred during the year.
Reserve Revisions. Changes to prior year-end proved reserves estimates, either positive or negative, resulting from new information other than an increase in proved acreage (extension). Revisions include increases of proved reserves associated with the installation of improved recovery techniques or equipment. They also include correction of prior report year arithmetical or clerical errors and adjustments to prior year-end production volumes to the extent that these alter reported year reserves estimates.

Reservoir. A porous and permeable underground formation containing an individual and separate natural accumulation of producible hydrocarbons (oil and/or gas) which is confined by impermeable rock or water barriers and is characterized by a single natural pressure system.

Residual Fuel Oil. The heavier oils that remain after the distillate fuel oils and lighter hydrocarbons are distilled away in refinery operations. Included are No. 5, a residual fuel oil of medium viscosity; Navy Special, for use in steam-powered vessels in government service and in shore power plants; No. 6, which includes Bunker C fuel oil, and is used for commercial and industrial heating, electricity generation and to power ships.

Kesiduum. Residue from crude oil after distilling off all but the heaviest components, with a boiling range greater than 1000 ) degrees Fahrenheit.

Retailer. A firm (other than a refiner, reseller, or reseller/retailer) that carries on the trade or business of purchasing refined petrolcum products and reselling them to ultimate consumers without substantially changing their form.

Road Oil. Any heavy petroleum oil, including residual asphaltic oil used as a dust palliative and surface treatment on roads and highways. It is generally produced in six grades from 0 , the most liquid, to 5 , the most viscous.

Rotary Rig. A machine, used for drilling wells, that employs a rotating tube attached to a bit for boring holes through rock.

Sales for Resale. Sales of refined petroleum products to purchasers who are other-than-ultimate consumers; wholesale sales.

Sales to End Users. Sales made directly to the consumer of the product. Includes bulk consumers such as agriculture, industry, and utilities, as well as residential and commercial consumers. 
Shell Storage Capacity. The design capacity of a petroleum storage tank which is always greater than or equal to working storage capacity.

Solvent Deasphalting. A process for removing asphaltic and resinous materials from reduced crude oils, lubricating oil stocks, gas oils, or middle distillates through the extraction or precipitant action of solvents, The principal deasphalting solvents are low-innlecular/weight hydrocarbons, particularly liquid propane, aho axygenated compounds, such as alcohols and esters.

Sour Crude. Crude oil containing an abnormally large amount of sulfur compounds which, upon refining, liberate corrosive sulfur compounds.

Special Naphthas. All finished products within the naphtha boiling range that are used as paint thinners, cleaners, or solvents. These products are refined to a specified flash point. Special naphthas include commercial hexane and cleaning solvents. Naphthas to be blended or marketed as motor gasoline or aviation gasoline, or that are to be used as petrochemical and synthetic natural gas (SNG) feedstocks are excluded.

Specific Gravity. The ratio of the weight of a volume of a body to the weight of an equal volume of some standard substance. In the case of liquids and solids, the standard is water; in the case of gases, the standard is hydrogen or air.

Spot Price. A transaction price concluded "on the spot," that is, on a one-time, prompt basis, usually the transaction involves only one specific quantity of product. This contrasts with a term contract sale price, which obligates the seller to deliver a product at an agreed frequency and price over an extended period.

Still Gas (Refinery Gas). Any form or mixture of gases produced in refineries by distillation, cracking, reforming, and other processes. The principal constituents are methane, ethane, ethylene, normal butane, butylene, propane, propylene, ctc. Still gas is used as a refinery fuel and a petrochemical feedstock.

Stocks, Crude Oil. Crude oil and lease condensate held at refineries, in pipelines, at pipcline terminals, and on leases.

Stocks, Primary. Stocks of crude oil or petroleum products held in storage at (or in) leases, refineries, natural gas processing plants, pipelines, tank farms, and bulk terminals. Crude oil that is in transit from Alaska, or that is stored on Federal leases or in the Strategic Petroleum Reserve, is included. Excluded are stocks of foreign origin that are held in bonded warehouse storage.
Straight-Run Product. A product produced by the primary distillation of crude oil.

Strategic Petroleum Reserve (SPR). Petroleum stocks maintained by the Federal Government for use during periods of major supply interruption.

Stripper Well. A well whose average daily production of crude oil (excluding condensate recovered in nonassociated natural gas production) did not exceed an average of 10 barrels per day during any preceding consecutive 12-month period beginning after December 31, 1972.

Sulfur. A nonmetallic element of lemon-yellow color, sometimes known as "brimswne."

Sweet Crude. Crude oil containing little sulfur.

Tank Farm. An installation used by gathering and trunk pipeline companies, crude oil producers, and terminal operators (except refineries) to store crude oil.

Thermal Cracking. A refining process in which heat and pressure are used to break down, rearrange, or combine hydrocarbon molecules. Thermal cracking includes visbreaking, fluid coking, delayed coking, and other thermal cracking processes (e.g., flexicoking).

Throughput. The volume of feedstock charged to process equipment in a specified time.

Toluene, An aromatic hydrocarbon, $\left(\mathrm{C}_{6} \mathrm{H}_{5} \mathrm{CH}_{3}\right)$, somewhat similar to benzene but of a higher boiling point produced in the coking of coal and also by petroleum refining processes. It is the basis of dyes, explosives, and aromatic compounds. Along with xylene, it is a key component in unleaded gasoline.

Topping. The distillation of crude oil to remove light fractions only.

Topping Refinery. A refinery that has only a distillation tower, a reformer, and some sulfur treating capability.

Turnaround. Time necessary to clean and make repairs on refinery equipment after a normal run. It is the clapsed time between drawing the fires (shutting the urit down) and putting the unit onstream again.

Unaccounted for Crude Oil. Represents the arithmetic difference between the calculated supply and the calculated disposition of crude oil. The calculated supply is the sum of crude oil production plus imports minus changes in crude 
oil stocks. The calculated disposition of crude oil is the sum of crude oil input to refineries, crude oil exports, crude oil burned as fuel, and crude oil losses.

Undiscovered Recoverable Resources (crude oil and natural gas). Those economic resources of crude oil and natural gas, yet undiscovered, that are estimated to exist in favorable geologic settings.

Unfinished Oils. Includes all oils requiring further processing, except those requiring only moshanical blending. Includes naphthas and lighter oils, kf;rosene and light gas oils, heavy gas oils, and residuum.

Unfractionated Streams. Mixtures of unsegregated natural gas liquid components excluding those in plant condensate. This product is extracted from natural gas.

Vacuum Distillation. Distillation under reduced pressure (less than atmospheric) which lowers the boiling temperature of the liquid being distilled. This technique with its relatively low temperatures prevents cracking or decomposition of the charge stock.

Visbreaking. A thermal cracking process in which heavy atmospheric or vacuum distillation bottoms are cracked at moderate temperatures to increase production of distillate products and reduce viscosity of the distillation residues.
Volatility. 'The extent to which liquids vaporize; the relative tendency to vaporize.

Wax. A solid or semi-solid material derived from petroleum distillates or residues by such treatments as chilling, precipitating with a solvent, or de-oiling. It is a lightcolored, more-or-less translucent crystalline mass, slightly greasy to the touch, consisting of a mixture of solid hydrocarbons in which the paraffin series predominates. Includes all marketable wax whether crude scale or fully refined. The three grades included are microcrystalline, crystalline-fully refined, and crystalline-other.

Well. A hole drilled for the purpose of finding or producing crude oil or natural gas or providing services related to the production of crude oil or natural gas. Wells are classified as oil wells, gas wells, dry holes, stratigraphic or core iests, or service wells.

Working Storage Capacity. The difference in volume between the maximum safe fill capacity of a storage tank and the quantity below which pump suction is ineffective (bottoms).

Xylene. An aromatic hydrocarbon, $\left(\mathrm{C}_{6} \mathrm{H}_{4} \mathrm{Y}\left(\mathrm{CH}_{3}\right)_{2}\right)$, produced in pctroleum refining (cracking) processes. One important use is as a solvent in the manufacture of paints. Along with toluene, it is a key ingredient in unleaded gasoline. 

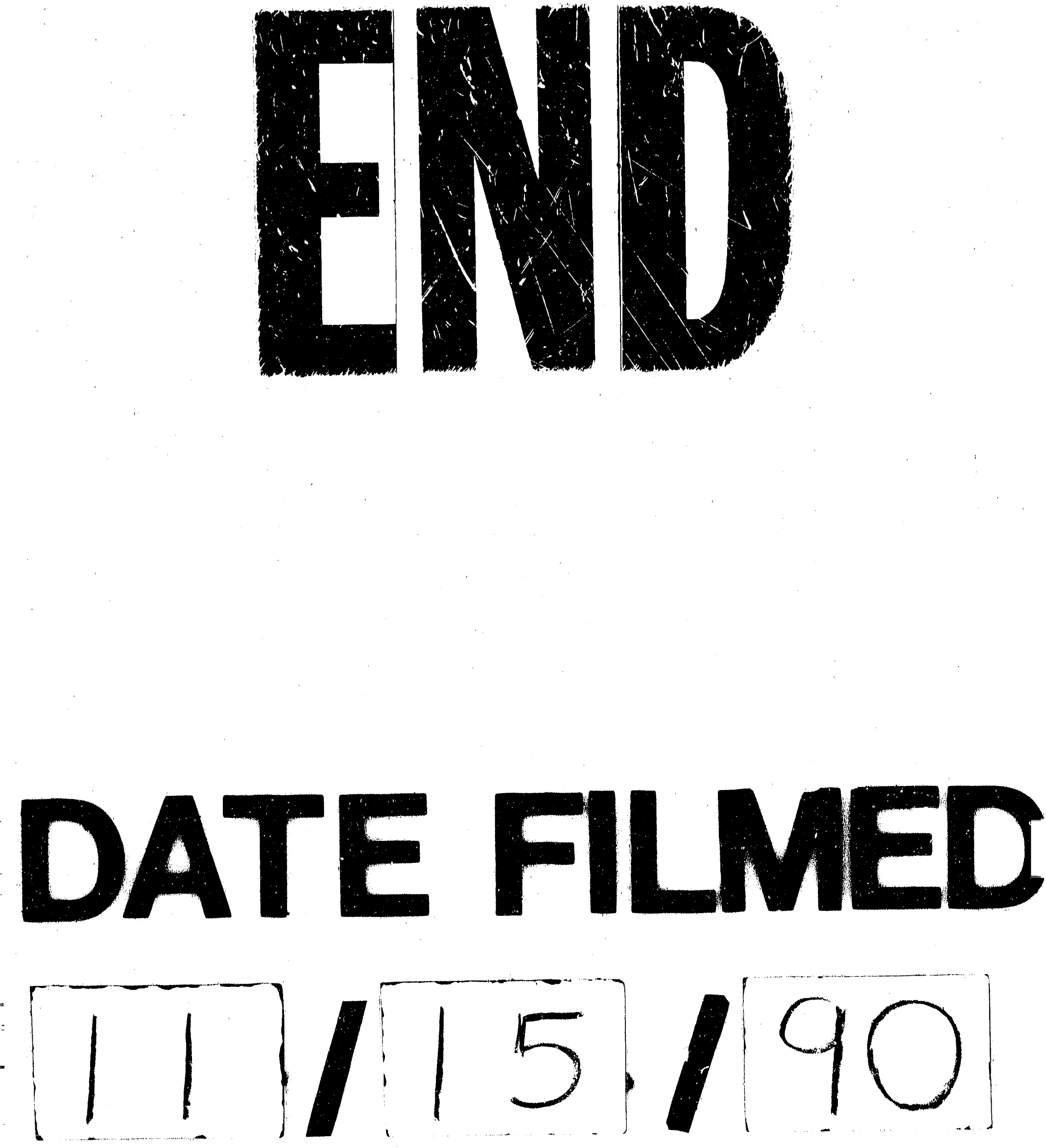
